UNIVERSIDADE DE SÃO PAULO

FACULDADE DE FILOSOFIA, LETRAS E CIÊNCIAS HUMANAS

DEPARTAMENTO DE GEOGRAFIA

PROGRAMA DE PÓS-GRADUAÇÃO EM GEOGRAFIA HUMANA

BRUNO DANTAS HIDALGO

Aspectos geográficos da participação popular na gestão urbana:

os Conselhos Participativos das Prefeituras Regionais

do Município de São Paulo

Versão Corrigida

São Paulo

2018 
UNIVERSIDADE DE SÃO PAULO

FACULDADE DE FILOSOFIA, LETRAS E CIÊNCIAS HUMANAS

DEPARTAMENTO DE GEOGRAFIA

PROGRAMA DE PÓS-GRADUAÇÃO EM GEOGRAFIA HUMANA

BRUNO DANTAS HIDALGO

\section{Aspectos geográficos da participação popular na gestão urbana: \\ os Conselhos Participativos das Prefeituras Regionais do Município de São Paulo}

\section{Versão Corrigida}

Dissertação apresentada ao Programa de PósGraduação em Geografia Humana, da Faculdade de Filosofia, Letras e Ciências Humanas da Universidade de São Paulo para obtenção do título de Mestre em Geografia Humana.

Orientador: Prof. Dr. Elvio Rodrigues Martins De acordo,

São Paulo $09 / 05 / 2018$ 

HIDALGO, Bruno D. Aspectos geográficos da participação popular na gestão urbana: os Conselhos Participativos das Prefeituras Regionais do Município de São Paulo. Dissertação apresentada à Faculdade de Filosofia, Letras e Ciências Humanas da Universidade de São Paulo para obtenção do título de Mestre em Geografia Humana.

Aprovado em: 12/03/2018

\section{Banca Examinadora}

Prof. Dr. Elvio Rodrigues Martins Instituição: Universidade de São Paulo (Orientador - Presidente da Banca)

Julgamento: Não votante

Prof. ${ }^{a}$ Dr. ${ }^{a}$ Isabel Aparecida Pinto Alvarez Instituição: Universidade de São Paulo

Julgamento: Aprovado

Prof. Dr. Mário Leal Lahorgue Instituição: Universidade Federal do Rio Grande do Sul

Julgamento: Aprovado

Prof. ${ }^{a}$ Dr. ${ }^{a}$ Terezinha Ferrari Instituição: Centro Universitário Fundação Santo André

Julgamento: Aprovado 


\section{AGRADECIMENTOS}

Esse trabalho não seria possível sem a confiança e a parceria do meu orientador, Elvio Martins, que teve importância decisiva na minha formação e cujas reflexões e conselhos são sempre inspiradores e certeiros.

Agradeço à USP, ao Programa de Pós-Graduação em Geografia Humana e aos professores que contribuíram participando da banca de qualificação e da defesa da dissertação: Isabel Alvarez, Mario Lahorgue, Terezinha Ferrari e Rita Cruz.

Agradeço aos colegas do Laboratório de Geografia Política e Planejamento Territorial e Ambiental - LABOPLAN pelo acolhimento, apoio e trocas de ideias. Agradeço sobretudo à Aline Oliveira, Ana Pereira, Bruno Cândido, Daniel Huertas, Flavio Vendrusculo, Igor Venceslau, Luciano Duarte, Mariana Avanzi, Mateus Sampaio, Melissa Steda, Wagner Nabarro e Victor Iamonti.

Agradeço aos amigos da Coordenação de Geografia do IBGE pelo inestimável apoio e incentivo a realização dessa pesquisa, em especial Adma Figueiredo, Ana Costa, Cayo Franco, Camilla Motta, Claudio Stenner, Daiane Batista, Dalea Antunes, Diogo Cabral, Evelyn Arruda, Evelyn Meirelles Gustavo Pinho, Marcelo Delízio, Marcelo Motta, Maria Amélia Vilanova, Maria Lúcia Vilarinhos, Mario Rangel, Melissa Martingil, Ronaldo Carvalho, Thalita Lima, Thiago Gervásio.

Sou muito grato aos conselhos participativos municipais das prefeituras regionais/subprefeituras, especialmente aos conselhos de Campo Limpo, Cidade Ademar/Pedreira, Freguesia do Ó/Brasilândia, Itaquera, Parelheiros, Pinheiros e Sé; principalmente a Danilo e Patrícia (Pinheiros); Sindy e Paulo (Cidade Ademar); Cida (Campo Limpo); Washington e Zildo (Itaquera); Marcos (Brasilândia); Alberto, Artur, Cássio e Cassiano (Sé). Agradeço também a todos os servidores e colaboradores das subprefeituras e a diversos conselheiros que atenderam às minhas solicitações de contatos, entrevistas e conversas informais.

Aos meus pais, Maria e Alexandre Hidalgo, e aos meus irmãos, Alexandre, Alessandra Gustavo e Rodrigo Hidalgo, pela recepção paciente e calorosa em todas às vezes que precisei voltar. Da mesma forma, agradeço a Claudia e Carlos Eduardo Azevedo pelo apoio que me ofereceram no processo de mudança de cidade pelo qual tive que passar nesses anos. 
Um agradecimento especial à Maíra Azevedo pela enorme paciência e conforto nos momentos difíceis dessa jornada e por não me deixar parar. Estar próximo a Maíra é motivador e inspirador. Conte comigo sempre!

Deixo também minhas saudações a todos aqueles que de alguma forma contribuíram para este trabalho e não foram citados nas linhas anteriores. Dedico os esforços aqui consubstanciados para todos os que se desdobram para conseguir participar de iniciativas políticas coletivas e que ocupam os espaços institucionais de participação disponíveis, mesmo sabendo de todas as limitações e dificuldades dessas instâncias. 


\section{RESUMO}

HIDALGO, Bruno D. Aspectos geográficos da participação popular na gestão urbana: os Conselhos Participativos das Prefeituras Regionais do Município de São Paulo. 2018. 130 p. Dissertação (Mestrado em Geografia Humana) - Faculdade de Filosofia, Letras e Ciências Humanas, Universidade de São Paulo, São Paulo, 2018.

Após o processo de redemocratização do Brasil e da promulgação da Constituição de 1988, diversas instituições e instrumentos de gestão e planejamento do Estado implementaram em sua estrutura organizacional canais de participação popular. Na gestão das cidades essa tendência foi muito expressiva - sobretudo após a elaboração do Estatuto das Cidades - e muitas vezes foi acompanhada de medidas de descentralização administrativa. Considerando esse contexto, esta pesquisa tem o propósito de discutir os limites e possibilidades da participação popular na gestão urbana institucional por meio da análise dos conselhos participativos municipais (CPM) das Prefeituras Regionais do Município de São Paulo. Os CPM são instâncias que propõem políticas para os territórios paulistanos, além de apoiar e fiscalizar a administração descentralizada das prefeituras regionais. Para realizar essa investigação executou-se duas etapas metodológicas principais. Primeiramente, analisaram-se alguns indicadores de condições geográficas dos territórios paulistanos de modo a identificar prováveis desigualdades de possibilidades de participação da população nos CPM, em razão de piores ou melhores condições de vida nos distritos e locais de residência. Em seguida, buscou-se identificar os resultados práticos da ação dos CPM em medidas de planejamento e produção da cidade. $\mathrm{O}$ detalhamento do funcionamento concreto dos CPM foi obtido a partir de visitas a reuniões ordinárias em algumas prefeituras regionais e por meio de relatos e entrevistas semiestruturadas realizadas com conselheiros presentes nessas reuniões. De modo geral, observou-se que a pouca autonomia administrativa e orçamentária das prefeituras regionais tem impacto negativo sobre as possibilidades de intervenção dos CPM. Além disso, a própria normatização dos CPM que restringe sua atuação a um caráter meramente consultivo associada a frequente falta de apoio dos gabinetes das prefeituras regionais, acaba por desmobilizar os participantes, muitos deles passando a se ausentar das reuniões por se sentirem ignorados e sem poder efetivo. Contudo, apesar dos desafios e limitações de atuação dos CPM, grande parte dos conselheiros ativos destacam a importância do órgão, e alguns atribuem certas ações nos territórios à pressão dos conselhos. Os limites da atuação dos conselhos expõem contradições inerentes a uma sociedade em que os rumos da produção da geografia das cidades são restritos a círculos políticos e econômicos privilegiados. A resolução da demanda social por maior participação política acaba sendo efetivada apenas no plano formal.

Palavras-chave: participação popular; conselhos participativos; descentralização administrativa; gestão urbana participativa; prefeituras regionais; subprefeituras 


\begin{abstract}
HIDALGO, Bruno D. Geographical aspects of popular participation in urban management: the Municipal Participative Councils of São Paulo Regional Prefectures. 2018. 130 p. Dissertação (Mestrado em Geografia Humana) - Faculdade de Filosofia, Letras e Ciências Humanas, Universidade de São Paulo, São Paulo, 2018.

After the process of redemocratization in Brazil and the promulgation of the Constitution of 1988, several institutions and instruments of state management and planning implemented in their organizational structure ways of popular participation. In the management of cities, this tendency was very expressive - especially after the elaboration of the "Estatuto das Cidades" (City Statute) - and was often accompanied by measures of administrative decentralization. Considering this context, this research aims to discuss the limits and possibilities of popular participation in institutional urban management through the analysis of Municipal Participative Councils (MPC) of São Paulo Regional Prefectures. MPC are instances that propose policies for São Paulo territories, in addition to supporting and supervising the decentralized administration of regional prefectures. To carry out this research was executed two main methodological steps. Firstly, some indicators of geographic conditions in São Paulo territories were analyzed in order to identify probable inequalities of possibilities of participation of the population in the MPC, due to worse or better living conditions in the districts and places of residence. Next, we sought to identify the practical results of the action of MPC in the planning and production measures of the city. The detailing of the operation of MPC were obtained from visits to ordinary meetings in some regional prefectures and through semi-structured reports and interviews with counselors present at these meetings. In general, it was observed that the low administrative and budgetary autonomy of regional municipalities has a negative impact on the possibilities of MPC intervention. Moreover, the regulatory standards of MPC, which restricts their activities to a merely consultative nature, associated with the frequent lack of support from the regional governments offices, demobilize the participants, many of whom are absent from meetings because they feel ignored and unable to participate effective. However, despite the challenges and limitations of the MPC, most active counselors emphasize the importance of the institution, and some attribute certain actions in the territories to the pressure of the councils. The limits of the council's performance expose contradictions inherent in a society in which the directions of the production of the geography of cities are restricted to certain privileged political and economic circles. The solution to the social demand for greater political participation ends up being carried out only in the formal plane.
\end{abstract}

Keywords: popular participation; participative councils; administrative decentralization; participative urban management; regional prefectures; subprefectures 


\section{LISTA DE ABREVIATURAS E SIGLAS}
ARs
Administrações Regionais
CEP
Código de Endereçamento Postal
CET
Companhia de Engenharia de Tráfego de São Paulo - SP
$\mathrm{CPM}$
Conselho(s) Participativo(s) Municipal(is)
Correios
Empresa Brasileira de Correios e Telégrafos
CADES
Conselho Municipal do Meio Ambiente e Desenvolvimento Sustentável
CADES Regionais
Conselho Regional de Meio Ambiente, Desenvolvimento Sustentável e Cultura de Paz das Prefeituras Regionais
CMPU
Conselho Municipal de Política Urbana
CONSEG
Conselho Comunitário de Segurança
CPOP
Conselho de Orçamento e Planejamento Participativos
$\mathrm{DOM}$
Diário Oficial do Município
Eletropaulo
Eletricidade de São Paulo S.A.
LDO
Lei de Diretrizes Orçamentárias
LOA
Lei Orçamentárias Anual
LPUOS
Lei de Parcelamento, Uso e Ocupação do Solo
Metrô
Companhia do Metropolitano de São Paulo
PDE
Plano Diretor Estratégico
PPA
Plano Plurianual
PMSP
Prefeitura do Município de São Paulo
PMSP-SMSP
Secretaria Municipal de Coordenação das Subprefeituras
PSDB
Partido da Social Democracia Brasileira
PT
Partido dos Trabalhadores
Regionais
Administrações Regionais ou Prefeituras Regionais
Sabesp
Companhia de Saneamento Básico do Estado de São Paulo
SPTrans
São Paulo Transportes S.A.
STF
Supremo Tribunal Federal
TJ-SP
Tribunal de Justiça do Estado de São Paulo 


\section{LISTA DE ILUSTRAÇÕES}

Figura 1 - Sistema Municipal de Planejamento Urbano do Município de São Paulo - 2016 .. 48

Figura 2 - Reunião do CPM de Cidade Ademar em 30/09/2017 ............................................55

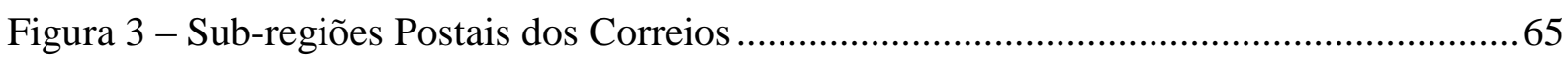

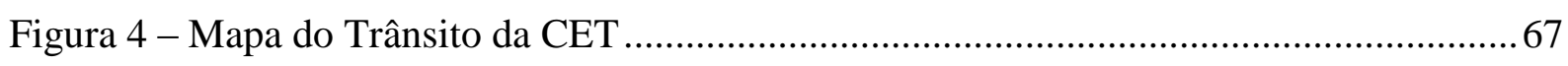

Figura 5 - Divisão do Município de São Paulo em Áreas de Concessão da SPTrans ............. 68

Figura 6 - Placas de identificação de ruas em São Paulo...................................................... 70

Figura 7 - Reunião ordinária do CPM de Itaquera em 28/09/2017 ..................................... 106

\section{LISTA DE MAPAS}

Mapa 1 - Distritos do Município de São Paulo a partir de 1992 ............................................. 38

Mapa 2 - Subprefeituras do Município de São Paulo a partir de 2002 ................................... 44

Mapa 3 - Regiões [zonas cardeais], subprefeituras e distritos do Município de São Paulo ....62

Mapa 4 - Divisão do Município de São Paulo em distritos, subprefeituras e zonas cardeais.. 64

Mapa 5 - Quantidade de população por distrito do município de São Paulo - 2010............... 80

Mapa 6 - Duração média das viagens (min) por distrito do Município de São Paulo - 2007.. 84

Mapa 7 - Percentual da população de 18 anos ou mais com ensino médio completo por

prefeituras regionais do Munícipio de São Paulo - 2010 ...................................................... 88

Mapa 8 - Renda per capita média (R\$) por prefeituras regionais do Município de São Paulo -

2010

Mapa 9 - Índice de Desenvolvimento Humano Municipal por prefeitura regional do

Município de São Paulo- 2010 . 92

Mapa 10 - Concorrência (candidato/vaga) na eleição de 2015 dos CPM no Município de São

Paulo 110

Mapa 11 - Concorrência (candidato/vaga) na eleição de 2017 dos CPM no Município de São Paulo 


\section{LISTA DE QUADROS}

Quadro 1 - Divisões territoriais de órgãos públicos para gerência de serviços e coleta de dados do Município de São Paulo

\section{LISTA DE TABELAS}

Tabela 1- População Recenseada, Taxas de Crescimento Populacional e Densidade Demográfica nas subprefeituras do Município de São Paulo - 2010

Tabela 2 - Duração média das viagens, em minutos, por distritos do Município de São Paulo 2007

Tabela 3 - Percentual da população de 18 anos ou mais com ensino médio completo por prefeituras regionais do Munícipio de São Paulo - 2010.

Tabela 4 - Renda per capita média (R\$) por prefeituras regionais do Município de São Paulo 2010

Tabela 5 - Índice de Desenvolvimento Humano Municipal por prefeitura regional do Município de São Paulo- 2010

Tabela 6 - Despesas liquidadas ( $\mathrm{R} \$$ e percentual) pelas prefeituras regionais, por tipo de projeto ou atividade -2016 99

Tabela 7 - Orçamento municipal $(\mathrm{R} \$)$ por prefeitura regional -2017. 100

Tabela 8 - Concorrência (candidato/vaga) e variação percentual da concorrência nas eleições dos CPM entre 2013 e 2017, por prefeitura regional 


\section{SUMÁRIO}

INTRODUÇÃO

1. DESCENTRALIZAÇÃO E PARTICIPAÇÃO POLÍTICA NA GESTÃO DAS CIDADES E NAS PREFEITURAS REGIONAIS DO MUNICÍPIO DE SÃO PAULO. 18

1.1 A gestão das cidades, a descentralização e a participação política 18

1.2 Gestão urbana descentralizada e a implementação das prefeituras regionais no Município de São Paulo

1.2.1 Experiências de descentralização política-administrativa do Município de São Paulo

1.2.2 Redemocratização, autonomia municipal e novas tendências de gestão pública.....34

1.2.3 A implementação das prefeituras regionais no Município de São Paulo 38

1.3 As instâncias participativas paulistanas e os conselhos participativos municipais 47

1.3.1 Instâncias participativas no Sistema Municipal de Planejamento Urbano.

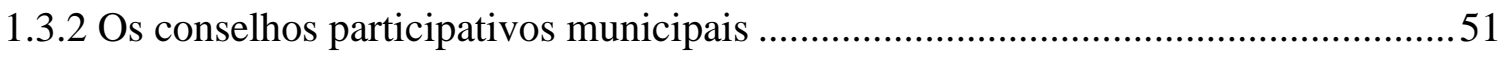

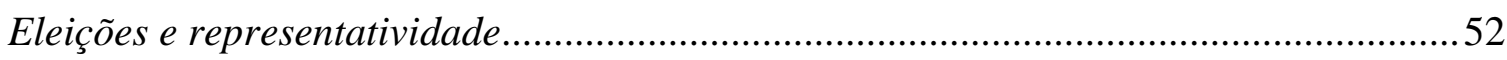

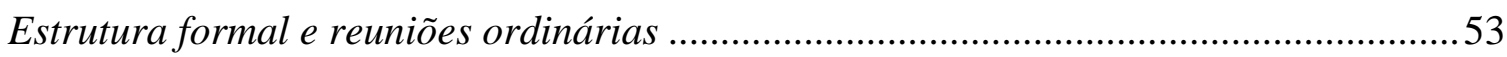

2. CONDIÇÕES GEOGRÁFICAS DA PARTICIPAÇÃO POPULAR NAS

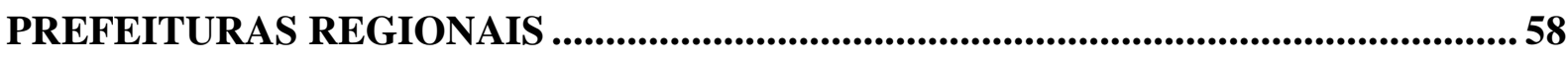

2.1 Referências espaciais da cidade e a participação política .....................................59

2.2 A cidade e as condições desiguais de participação política nos conselhos

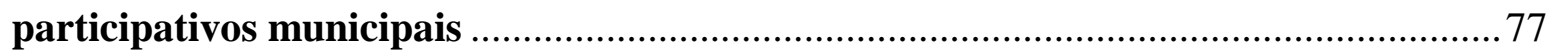

2.2.1 Distribuição demográfica e representatividade por território .................................. 77

2.2.2 Situação e acessibilidade dos territórios paulistanos e dos espaços de reunião ........82

2.2.3 Desigualdades socioeconômicas entre as populações e territórios das regionais .... 86

2.3 A influência das condições geográficas de participação segundo a experiência dos conselheiros dos conselhos participativos municipais

3. POSSIBILIDADES E LIMITES DE PRODUÇÃO DO ESPAÇO URBANO NAS PREFEITURAS REGIONAIS POR MEIO DA PARTICIPAÇÃO POPULAR ............96

3.1 Limites da autonomia das prefeituras regionais e os CPM: questões orçamentárias

3.2 Limites da autonomia das prefeituras regionais e os CPM: atribuições e intervenções político-partidárias

3.3 Resultados e desafios da participação popular nos conselhos participativos municipais 
3.3.1 A relação entre as prefeituras regionais e os conselhos participativos municipais 108

3.3.2 Os grupos políticos nos conselhos participativos.................................................. 109

3.3.3 A questão das ausências de conselheiros e munícipes ........................................... 109

3.3.4 Projetos aprovados no âmbito dos CPM colocados em prática nos territórios ...... 113

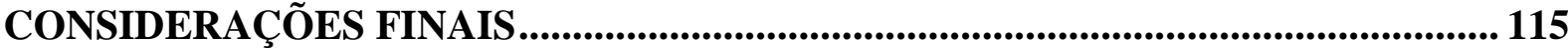

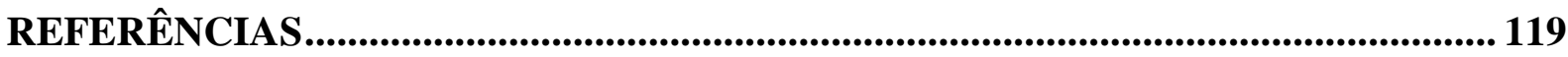

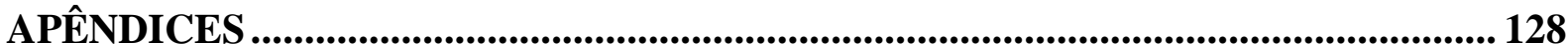

APÊNDICE A - Questionário semiestruturado destinado a conselheiros e munícipes

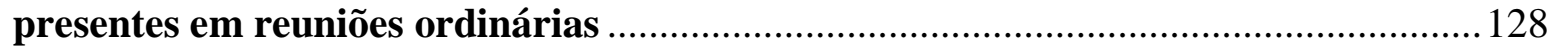

APÊNDICE B - Localização dos conselhos participativos municipais visitados e consultados na pesquisa 


\section{INTRODUÇÃO}

Um dos traços geográficos mais significativos do século XXI é a presença de Estados nacionais em praticamente todas as áreas do planeta, delimitando nichos de soberania e atuações políticas diversas, de maneira direta, indireta, material ou simbólica. Os Estados quase sempre estão atrelados a territórios organizados internamente por meio de limites espaciais, definindo áreas de autonomia política regional, local ou realizando subdivisões para fins administrativos e operacionais. Tratam-se de fenômenos que se consolidaram na modernidade e que hoje constituem as formas dominantes de organização política das sociedades. Nas últimas décadas do século XX e início do século XXI, no entanto, um outro fenômeno tem cada vez mais acompanhado as divisões espaciais para fins administrativos dos Estados: a tendência a incorporação da participação popular nos processos de planejamento e gestão pública dos territórios. Ora essa participação é mais direta ou indireta, ora mais formal ou informal, mas se nota que o discurso da participação tem sido cada vez mais presente nas instituições. Segundo Lavalle et al. (2016, p. 609), alguns números mostram claramente essa tendência no Brasil: “existem aproximadamente 30 mil conselhos gestores de políticas públicas [...] nos 5.570 municípios do Brasil, e, por conseguinte, várias dezenas de milhares de conselheiros da sociedade civil participando na definição e na supervisão de políticas públicas”.

Na gestão urbana esse fenômeno é ainda mais sensível do que nas esferas centrais de poder estatal, na medida em que as cidades são locais em que os habitantes podem acompanhar mais de perto os impactos do planejamento estatal. No Brasil, os debates sobre participação emergem sobretudo a partir dos anos 1980, e depois da promulgação da Constituição de 1988 são institucionalizados e consolidam-se na forma de conselhos e fóruns correlatos. A questão urbana foi um dos temas mais requisitados para aumento da participação popular, de modo que um dos marcos legais mais importantes nesse assunto é o Estatuto das Cidades (BRASIL, Lei $n^{\circ} 10.257,2001$ ), o qual expressa a obrigação de controle social dos instrumentos de política urbana e a garantia de participação nos processos de planejamento. Nesse sentido, já na década de 1990, constataram-se iniciativas de pluralizar formas de representação extraparlamentar e criação de núcleos de institucionalização da participação, como os conselhos de políticas públicas, criando um limite tênue entre essas duas dimensões - participação e representação -, as quais muitos analistas opuseram radicalmente em décadas anteriores (LAVALLE; VERA, 2011). 
A tendência a subdividir o território interno do Estado para fins administrativos e de criar instâncias participativas no planejamento por vezes são iniciativas que ocorrem concomitantemente, não raro sob um mesmo projeto. A Lei Orgânica do Município de São Paulo (SÃO PAULO, 1990) previa a criação de subprefeituras - atualmente denominadas prefeituras regionais (ou simplesmente "regionais") -, como estruturas de auxílio a prefeitura em nível local, e do conselho de representantes, para institucionalizar a participação cidadã. Essas duas instâncias foram pensadas para atuar conjuntamente, no mesmo arranjo territorial as áreas das regionais. Em 2002 elas foram implementadas como estruturas regionalizadas do poder executivo municipal (SÃO PAULO [Município], Lei n ${ }^{\circ}$ 13.399, 2002), com a pretensão de integrar políticas públicas setoriais nos territórios da cidade, assim como aproximar a gestão dos cidadãos em seus territórios. Embora não tenha sido a única iniciativa com esses propósitos $^{1}$, trata-se de uma experiência muito significativa e simbólica pois pretende simular no imaginário da população a autonomia das prefeituras em níveis territoriais menores². Ademais, o destaque das prefeituras regionais é percebido pelo fato de muitas outras instâncias de governo as utilizarem como base para escolha de seus representantes, como alguns dos conselhos setoriais, como o Conselho Municipal de Política Urbana (CMPU), os quais designam integrantes a partir da indicação de pessoas que atuam nas prefeituras regionais paulistanas. A principal instância participativa que opera no âmbito das prefeituras regionais são os conselhos participativos municipais (CPM), fórum de munícipes eleitos que representam os moradores em cada prefeitura regional. Trata-se de uma instância criada em 2013 em caráter provisório, enquanto o mérito do conselho de representantes não fosse aprovado no Supremo Tribunal Federal (STF).

Apesar de funcionarem há mais de uma década, há indícios de que as prefeituras regionais não conseguiram atender satisfatoriamente ao objetivo de aproximar a gestão urbana aos cidadãos e de permitir uma participação popular efetiva em decisões primordiais de produção do espaço urbano. Um indicador quantitativo desse diagnóstico é a baixa adesão da população às eleições para os conselhos participativos municipais. A participação no último

\footnotetext{
${ }^{1}$ A iniciativa mais relevante de descentralização da gestão municipal em São Paulo anterior a implementação das subprefeituras aqui analisadas foram as administrações regionais (AR), que vigoraram de 1965 até a criação das subprefeituras em 2002. Do ponto de vista da participação popular, a incorporação mais significativa ocorreu na elaboração dos Planos Diretores Estratégicos em 2002 e 2014, os quais possuíram interfaces com os planos de ação das subprefeituras.

${ }^{2}$ Essa ideia de simular a autonomia municipal em territórios menores fica evidente quando observamos a mudança de nome das subprefeituras em 2017. Desde então, as subprefeituras passaram a ser as "prefeituras regionais", uma das primeiras medidas tomadas pelo prefeito João Doria Jr. ao assumir o mandato.
} 
processo eleitoral plenamente concluído, que se realizou em 2015, foi o de 42 mil eleitores (PMSP-RS, 2015), o que configura bem menos de $1 \%$ do total de eleitores no município (mais de 8 milhões de eleitores). Em 2017 o número de vagas para o conselho foi reduzido em torno de $50 \%$, sob alegação de que havia baixa frequência de conselheiros eleitos nas reuniões (20 a $30 \%$ ). Além disso, a iniciativa por vezes aventada de eleição direta do subprefeito/prefeito regional, que tornaria mais autônomas as unidades locais paulistanas, nunca conseguiu sair da esfera da especulação. Por outro lado, entre o 2008 e 2012 o comando das subprefeituras chegou a ser constituído em sua maioria por coronéis da Polícia Militar. A perda de importância da representação civil nesses fóruns representou, para muitos, na prática um processo de centralização das decisões dessas instituições.

Além de questões ligadas à autonomia política das prefeituras regionais, a hipótese de que a participação popular nos CPM não atingiu os resultados esperados pode ser investigada sob a dimensão geográfica. Um dos modos de se abordar essa questão é a partir da verificação das dificuldades impostas pelo cotidiano dos habitantes da cidade, tais como os longos deslocamentos necessários para se chegar à sede de uma prefeitura regional, o tempo livre escasso, a falta de recursos financeiros e materiais, etc. Há estudos que apontam uma correlação entre participação política, escolaridade e renda, por exemplo, sugerindo que a participação tenderia a ser maior de pessoas com esses indicadores mais altos (ALMEIDA, 2017). Em alguma medida, esses elementos podem sugerir que em determinados fragmentos da cidade a possibilidade de participação ocorre com maiores obstáculos.

A partir dessas reflexões, coloca-se o seguinte questionamento: quais são os limites da participação popular nos conselhos participativos das prefeituras regionais paulistanas? Sob uma perspectiva geográfica, emerge a indagação: de que forma a geografia da cidade pode potencializar ou dificultar a participação popular em fóruns institucionais de gestão urbana? Existem experiências relevantes de produção da geografia da cidade de São Paulo por meio da participação da população nos processos decisórios nas prefeituras regionais? Essa problemática, numa perspectiva mais geral, leva-nos à reflexão sobre a possibilidade - ou impossibilidade - de apropriação da territorialidade institucional por setores da sociedade que não detém cargos políticos estatais. Da mesma forma, essas indagações permitem-nos discutir se a estrutura estatal moderna consegue acomodar uma efetiva participação popular nas instâncias de governo, em harmonia com as instituições democráticas representativas vigentes. Os estudos com essa temática tornam-se ainda mais relevantes quando se consideram as 
recorrentes crises e questionamentos das instituições democráticas em diversos países e contextos contemporâneos. Seja de um ponto de vista progressista ou conservador, ora com ênfase nos vícios do sistema privado de financiamentos de campanhas eleitorais, ora enfatizando a corrupção, ora em razão da baixa adesão da população aos pleitos eleitorais, o fato é que há perspectivas críticas sobre a democracia representativa moderna. Nesse contexto, é comum observar demandas por maior transparência estatal e menor centralização das decisões políticas, que podem ser exemplificadas pela criação de conselhos em órgãos de governo e Estado.

Levando em consideração essa problemática, essa dissertação tem como objetivo identificar e analisar geograficamente limites e potencialidades da participação popular na gestão urbana em âmbito institucional, por meio da investigação da atuação dos conselhos participativos municipais nas prefeituras regionais de São Paulo, entre 2014 e 2017. Para atingir esse propósito, estabeleceu-se duas etapas metodológicas fundamentais. A primeira é buscar compreender de que formas a geografia da cidade pode facilitar ou criar obstáculos a participação cidadã nos espaços institucionais de gestão urbana, por meio da análise de alguns indicadores demográficos, socioeconômicos e geográficos que sugerem desigualdades de acesso à cidade entre os munícipes paulistanos, o que pode indicar um desequilíbrio nas possibilidades igualitárias de participação política. A segunda etapa consiste em procurar identificar os limites concretos da atuação dos CPM, por meio da observação do modo de organização prático dessa instância, e também considerando os limites administrativos e orçamentários das prefeituras regionais, bem como prospectando ações realizadas de produção e intervenção na cidade que foram decididas no âmbito dos CPM.

Não é objetivo desse trabalho fazer uma análise minuciosa da situação de todas as prefeituras regionais paulistanas, portanto para a realização de algumas das investigações foram escolhidas experiências de CPM específicos, de acordo com as possibilidades que se apresentaram de abertura a visitação, horários acessíveis de reuniões, disponibilidade de dados e atas, etc. Dada a dificuldade de se visitar todos os 32 CPM, devido à baixa frequência de reuniões e à grande variabilidade de agendas dos conselhos, optou-se pela visita de ao menos um CPM por macrozona do município: Sé (Centro); Freguesia do Ó/Brasilândia (Norte); Itaquera (Leste); Cidade Ademar (Sul). Outros CPM foram contatados e visitados, mas fora do âmbito das reuniões ordinárias (vide Apêndice 2). Além da visita às reuniões ordinárias de CPM, optou-se por captar parte das impressões dos conselheiros por meio de um questionário 
semiestruturado (Apêndice 1), de modo a constituir uma base comum para se averiguar as impressões dos conselheiros sobre determinados temas, ainda que não haja intenção de realizar uma análise estatística-quantitativa das respostas. Ademais, considerou-se do ponto de vista empírico os instrumentos normativos que regem a estrutura participativa municipal e uma caracterização geográfica do município sob a perspectiva socioeconômica e cartográfica/cadastral.

A dissertação está estruturada em três capítulos. O primeiro, intitulado Descentralização e participação política na gestão das cidades e nas prefeituras regionais de São Paulo, pretende realizar uma discussão sobre a gestão das cidades e o planejamento urbano contemporaneamente, considerando-se a inserção da participação popular nesse processo. Ainda neste capítulo, serão elencados e debatidos alguns dos principais marcos regulatórios na gestão urbana paulistana, bem como a elaboração do processo participativo nas prefeituras regionais do município.

O segundo capítulo, Condições geográficas da participação popular nas prefeituras regionais, realizará uma análise baseada em hipóteses sobre de que maneiras a geografia da capital paulista pode influenciar positiva ou negativamente a participação política nos conselhos das prefeituras regionais, em razão de condições socioeconômicas, materiais - como as localizações das sedes das regionais - e simbólicas - como as referências espaciais institucionais do município.

A última parte, Possibilidades e limites de produção da geografia urbana nas prefeituras regionais por meio da participação popular, versará sobre o funcionamento empírico desses entes municipais, por meio da análise de sua concreta autonomia orçamentária, administrativa e político-partidária, além de tentar detectar projetos de intervenção urbana que foram efetivamente de iniciativa popular por meio da atuação dos conselhos. Para realizar esse último quesito foram utilizadas sobretudo as impressões dos conselheiros ativos com os quais houve contato durante o período de pesquisa.

Apesar do escopo limitado do trabalho, espera-se que os resultados e análises propiciem discussões sobre as potencialidades e limitações da participação popular na gestão urbana, bem como sobre o papel da geografia nesse processo, enquanto fenômeno da realidade que impacta a sociedade, inclusive sua participação política. Além disso, espera-se que a abordagem aqui adotada para tratar fenômenos políticos e urbanos do ponto de vista geográfico mostre-se 
adequada ao objeto analisado. Sob uma perspectiva ampla, pretende-se contribuir para a discussão de possíveis momentos críticos e limites da democracia representativa moderna. 


\section{DESCENTRALIZAÇÃo E PARTicipaÇÃo POLÍtica NA GeSTÃo dAS CIDADES E NAS PREFEITURAS REGIONAIS DO MUNICÍPIO DE SÃO PAULO}

\subsection{A gestão das cidades, a descentralização e a participação política}

Atualmente a maioria da população mundial vive em cidades, a Organização das Nações Unidas (ONU) estima que cerca de 54\% dos habitantes concentram-se em algum tipo de aglomeração urbana ${ }^{3}$. Essa proporção é ainda superior quando se toma determinados continentes e regiões em particular, como a América Latina, que possui mais de $70 \%$ da população habitando essas áreas. Essa estimativa quantitativa é suficiente para afirmar a importância das cidades e identificar a intensificação da concentração populacional em áreas urbanas como um dos fenômenos geográficos mais característicos do mundo contemporâneo, sobretudo a partir do século XX.

A cidade tornou-se o habitat mais frequente das sociedades recentemente, no entanto a existência delas remonta há milênios. Há autores que contestam a validade de um conceito genérico de cidade em razão das variadas formas espaciais que se remetem a essa noção em contextos históricos e geográficos específicos (VASCONCELOS, 2015), apesar disso reconhecem-se algumas características citadinas relativamente perenes. De um ponto de vista morfológico mais imediato, tende-se a denominar cidade um objeto espacial que abriga uma densidade relativamente alta de habitações e pessoas quando comparada ao campo. Além disso, há certo consenso de que uma condição indispensável para a existência das cidades é um nível significativo de divisão social do trabalho e produção de excedentes agrícolas, de modo a permitir que uma parte expressiva da população possa obter seus meios de vida sem trabalhar no campo. Uma outra característica importante dos aglomerados citadinos é que eles normalmente constituem os centros políticos por excelência dos territórios, num primeiro momento ancorados em autoridades religiosas, mas também sendo os locais a partir dos quais organiza-se a defesa dos territórios, em que se estabelecem controles e normas para a apropriação dos excedentes produtivos e da população. As cidades dessa maneira tenderam a ser os pontos do território nos quais o Estado está sediado.

\footnotetext{
3 ONU-BR. Disponível em<https://nacoesunidas.org/atual-modelo-de-urbanizacao-e-insustentavel-onu-habitatrelatorio/>. Acesso em: 15 ago. 2017.
} 
Como centros de exercício de poder e ambiente de grande circulação de pessoas, mercadorias e ideias, a cidade foi frequentemente a arena preferencial de disputas políticas e revoltas. Em geral, as sociedades organizadas em cidades e que estavam submetidas a algum poder estatal com origem em outro núcleo, sempre tenderam a reivindicar algum grau de autonomia, que poderia ser representado por algum patamar de nobreza das autoridades ou por títulos oficiais, como "município" para os portugueses. Não por acaso foram em cidades, melhor dizendo, nas polis gregas, em que se tem o surgimento da noção de democracia. As polis do período clássico grego etimologicamente deram o sentido para a ideia de política e, mais do que isso, foram a experiência mais marcante da antiguidade de uma tentativa de descentralizar o poder de decidir os rumos da cidade.

É importante destacar que as características gerais mencionadas da cidade em diversos contextos históricos e geográficos não constituem uma essencialidade absoluta do conceito. Segundo Lefebvre (2008), o espaço urbano é produto das relações sociais de produção, bem como condição para essa reprodução. Nesse sentido, as cidades reproduzem a lógica social que as constituiu e, portanto, só podem ser compreendidas historicamente. Do mesmo modo, observa-se que embora a cidade constitua espaço privilegiado de expressão política e de disputas pelo poder, seu caráter condicionador das relações sociais tende a restringir as ações dos indivíduos àquelas que mantenham as relações de produção essencialmente intactas, o que significa manter as classes dominantes como dominantes mediante a apropriação privada dos produtos do trabalho socialmente produzido. Dessa forma, sob uma perspectiva crítica, há um componente estrutural que não permite ao poder local estabelecido nas formas vigentes redefinir todos os rumos da produção de sua própria geografia urbana. Essa redefinição mais profunda, essencialmente, só seria possível com a modificação das relações sociais de produção. Em assim sendo, a modificação da geografia urbana poderia ser parte da modificação das relações de produção, mas provavelmente essas alterações teriam que ser promovidas por mecanismos externos aos regimes políticos estabelecidos institucionalmente.

A modernidade estabelece-se juntamente com a Revolução Industrial e com a consolidação das relações de produção capitalistas. No processo de gênese desse período, as cidades comerciais europeias são apropriadas pela burguesia industrial emergente, como meio de concentração de trabalho e como potencial mercado consumidor para os produtos industriais. Segundo Lefebvre (2008), esse período é o ponto de inflexão em que o domínio da cidade passa da ruralidade para a urbanidade, ou seja, a classe dominante deixa de estar assentada sobre a 
produção agropecuária e os domínios de terras senhoriais e gradativamente passa a estar atrelada à burguesia e à produção industrial. Nesse processo, a urbanidade 'subjuga' o campo aos imperativos da produção capitalista e industrial, impondo a necessidade de redução de tempos de produção de produtos agrícolas, mercantilização da terra, arrendamentos e dissolução dos laços senhoriais. Do ponto de vista político, as cidades gradativamente deixam de ser governadas na prática por reis e nobres, e há o início do processo de formação do Estado de direito e da democratização em algumas cidades europeias, pautadas pela abertura à participação por meio de representação para nobres e detentores de posses. Dessa forma, criouse um novo arranjo institucional para regular a participação da população nas decisões dos rumos da cidade, mesmo que restritas a uma ínfima parcela dos cidadãos.

Houve um intenso processo de urbanização iniciado pós Revolução Industrial, reproduzindo as cidades como meio de produção para o capital industrial. A cidade assim passou a ser produzida sob os imperativos da circulação das matérias-primas, dos produtos industriais, do consumo e do trabalho. Essas novas necessidades redesenharam o tecido urbano das cidades previamente existentes, criaram novas cidades, e tenderam a expandir enormemente as manchas urbanas. Porém, ao mesmo tempo em que a cidade "explodia" em termos de expansão de seu tecido, ela "implodia" em razão da intensa fragmentação das centralidades, da criação de periferias, subúrbios e da dificuldade crescente em se gerar encontros e se estabelecer atividades não-produtivas ${ }^{4}$. A vida nas cidades aos poucos passou a constituir um problema, tanto do ponto de vista dos habitantes quanto da perspectiva da reprodução capitalista.

A partir do fim do século XIX e mais expressivamente no século XX foram sistematizadas ciências e técnicas dedicadas ao tratamento da problemática urbana, em decorrência da grande explosão urbana e de suas consequências. Dentre essas disciplinas destaca-se o urbanismo, cujos especialistas contribuíam para a construção das cidades sob a lógica da produção industrial. A noção de planejamento estabeleceu-se como alternativa para lidar com os problemas decorrentes da intensa urbanização, e o modernismo tornou-se paradigma de produção e intervenção na geografia urbana. Concomitantemente houve a incorporação de um aparato estatal burocrático composto por técnicos que decidiriam, sob critérios científicos, os rumos da produção da geografia urbana. Nota-se que a partir dessa lógica não fazia sentido acomodar uma participação mais próxima da população nas diretrizes

${ }^{4}$ Lefebvre (2008). 
das políticas urbanas, na medida em que esse era um trabalho que exigia conhecimentos científicos específicos e, portanto, ações tecnocráticas para gerir cidades.

As principais relações entre os agentes capitalistas privados e a cidade, até as décadas de 1960 e 70, ocorriam com o propósito de suprir a demanda por infraestruturas e mercado para a indústria. A cidade era vista, predominantemente, como o lugar que deveria abrigar a materialidade e o trabalho necessários para viabilizar as instalações industriais - mesmo com eventuais afastamentos de parte das indústrias dos núcleos mais densos dos centros urbanos, continuava-se necessitando do mercado e do trabalho residentes nas cidades, então as indústrias não poderiam estar completamente isoladas delas. Além disso, a cidade deveria permitir a rápida mobilidade das mercadorias e dos trabalhadores, bem como deveria estabelecer locais adequados para o consumo das mercadorias. Genericamente, pode-se afirmar que as necessidades do capital industrial eram as que norteavam o urbanismo e suas intervenções, de acordo com Santos (2006, p. 108) "[...] o espaço urbano passou a ser gerido, principalmente no século XX, em função dos capitais produtivos. A cidade moderna se transformou, à primeira vista, num amontoado de viadutos, pontes, túneis, cabos, antenas, trilhos, etc". Neste período, o urbanismo modernista era predominante nas intervenções de planejamento no urbano, a partir de uma visão de totalidade funcionalista da cidade. Era um tipo de planejamento dedicado a elaborar grandes planos totalizantes para os espaços urbanos, concretizados em muitos casos sob a forma de planos diretores. Esse urbanismo, de modo majoritário, pensava espaços separados para a produção, eminentemente industrial; para a circulação de mercadorias e pessoas, sobretudo por meio do automóvel; para os espaços de habitação, separando moradias dos executivos das empresas das moradias dos operários; e para os espaços de comércio e consumo, reservando lugares para o lazer e para as compras. Isso refletia o modo de organização da produção industrial da época, o fordismo, que ficou marcado por racionalizar a produção por meio de divisão das etapas produtivas. Além disso, foi um modelo econômico que concedeu aos trabalhadores mecanismos que os permitiam consumir, para que houvesse vazão à superprodução industrial. Segundo Lefebvre, essa formatação da vida urbana, operada em grande parte pelo urbanismo, pode ser considerada um mecanismo de reprodução das relações sociais de produção a partir do espaço, pois o espaço passou a ser um indutor do comportamento na produção e um modo de restringir as possibilidades de vida urbana improdutiva. De acordo com ele “[...] esses grafismos familiares aos arquitetos e urbanistas [...] intervém como redutores da realidade que eles pretendem re-presentar, e que não passa, aliás, de uma imagem 
do 'modo de vida' admitido, e consequentemente imposto, no habitat [...]" (LEFEBVRE, 2008, p.127, grifos do autor). Nessa perspectiva, o fordismo e o urbanismo modernista tiveram repercussão no modo como a cidade era representada espacialmente do ponto de vista político e administrativo, bem como no modo de inserção da população na definição dos rumos do urbano - neste caso, em grande medida impedindo a participação dos citadinos nesse processo.

Essa racionalidade do urbanismo e dos tecnocratas operava do ponto de vista político nas instituições que governavam as cidades. Desse modo, na perspectiva da administração estatal, as cidades encontram-se sob a jurisdição de um território nacional, e em geral estão sob responsabilidade de algum nível político estatal inferior ao poder central. Muitas vezes há a delegação de poderes específicos de gestão urbana a instâncias administrativas mais imediatas, como os municípios, no caso brasileiro, ou os condados, no caso norteamericano. Mais do que isso, a administração estatal das cidades opera de forma predominantemente setorial, ou seja, gerindo tematicamente a cidade, em assuntos como transporte, educação e coleta de impostos. Considerando os arranjos políticos intraestatais - como a formação de coalizações governistas entre poder executivo e legislativo e a distribuição de cargos em secretarias setoriais -, a fragmentação da gestão das cidades torna-se ainda mais complexa e profunda. Em razão disso, as cidades passaram a ter numerosos recortes espaciais para estabelecer os limites de ação de cada setor administrativo e tecnocrático do Estado. Assim, houve a tendência de que cada secretaria de um município, por exemplo, elaborasse sua própria regionalização do território, seguindo a típica divisão do trabalho rigorosa do fordismo. A cidade passava a ser representada funcionalmente dentro de uma lógica técnica específica, por esse motivo, dificilmente uma divisão territorial elaborada para o transporte seria a mesma de uma adotada para a educação: nos dois casos, os técnicos de cada uma das áreas sentiriam necessidade de produzir novos quadros territoriais. A partir desses pressupostos, somados ao fordismo e ao urbanismo modernista, consolidava-se uma perspectiva fragmentária da cidade, do urbano e da administração pública - burocratizada, tecnocrática e relativamente distante de tomadas de decisão com participação popular.

Esse modelo de planejamento e gestão das cidades produz representações materializadas em planos urbanos pensados para toda a cidade - quase sempre por meio de zoneamentos com funções específicas (áreas de comércio, áreas proteção, áreas residenciais, etc.) -, e planos específicos para setores da administração. Eventualmente, a falta de resultados dos instrumentos de planejamento são atribuídas, mesmo que de modo secundário, a ausência de 
uma administração integrada, referenciada a subcentralidades urbanas. É nesses contextos que surgem propostas de aumento de autonomia de aparatos administrativos regionais, como ocorreu com as prefeituras regionais paulistanas em diversos momentos da história recente da cidade.

Nota-se que muitas vezes as discussões sobre o planejamento urbano perdem de visa a lógica de produção da geografia das cidades, priorizando soluções relativas à mitigação das consequências da urbanização, partindo-se do pressuposto que os problemas atuais que as cidades enfrentam decorrem de uma falta de 'planejamento' em momentos anteriores. No entanto, concordando com Gottdiener (1993) há um componente anárquico na produção do espaço urbano, no qual os resultados frequentemente não são socialmente decididos ou planejados.

Esse panorama teria algumas modificações e novos elementos no último quartel do século XX. A crise do capital nos anos 1970 e 80, em grande parte crise do modelo fordista de produção industrial, criou outras formas de atuação dos agentes econômicos privados na cidade. A partir desse período houve uma intensa financeirização da economia e uma aceleração dos fluxos de capital, que passou a ter menores barreiras de circulação. O principal foco econômico para os capitalistas passou a ser a esfera financeira, e não mais a produção industrial de larga escala:

As baixas taxas de lucro, as barreiras a novas inversões e o aparecimento de excedentes de capital nos setores manufatureiros de forma geral - e principalmente naqueles ligados a uma alta composição de capital - definiram uma retirada brusca e intensiva de investimentos nesses setores para aqueles do financeiro (SANTOS, 2006, p.109).

O mercado imobiliário foi incorporado de modo mais profundo no sistema financeiro, pois passou a constituir uma das possíveis alternativas de investimento rentável em um momento crítico para o capital. Essa inserção mais intensa da esfera fundiária nos circuitos financeiros ocorreu por meio da criação de uma forma mobiliária à propriedade da terra e aos seus acessórios, de modo a garantir maior liquidez a um bem que tradicionalmente era visto mais como entrave ao capital do que como possibilidade de sua reprodução. A financeirização dos bens imobiliários ocorreu de vários modos. Além das hipotecas, acrescentou-se a negociação de títulos de propriedade fundiária, a comercialização de cotas em fundos de investimentos imobiliários, a negociação de seguros de empréstimos para quitação de residências, a venda de certificados de potencial adicional de construção, etc - boa parte desses negociados nas bolsas de valores. De acordo com Alvarez (2013, p.118), “[...] a ampliação do chamado capital fictício 
requereu mobilidade de circulação e criação de novos instrumentos (ou a proliferação de antigos [...]), sobretudo ligados ao setor imobiliário, para que pudesse dar vazão à parcela desse capital”. Essa transformação na lógica do capital teve impacto na produção das cidades e também na gestão das políticas urbanas.

Um dos fundamentos desse novo papel da terra na crise do capital consiste na possibilidade de remediar parcialmente a crise com a captação da renda da terra do solo urbano e com a especulação sobre os terrenos. A renda, tradicionalmente, é um pagamento feito ao proprietário para usar a terra e seus acessórios (HARVEY, 2013) em função da exclusividade que ele detém sobre o solo. Nas cidades esse pagamento pela terra muda constantemente em razão da dinâmica da renda diferencial de segundo tipo, conforme descrito por Harvey (2013), ou seja, a renda é modificada de acordo com as condições de acessibilidade do solo, a sua localização na cidade, os serviços de que dispõe nas redondezas, etc. Nesse sentido, quando se comercializa um bem imobiliário na cidade, a compra e venda não está referenciada apenas ao bem, mas também a renda que se pode auferir por meio dele. Em outras palavras, o preço da terra refletirá a renda futura que pode ser obtida por esse solo, trazida aos valores presentes. A aposta de que a renda auferida pelo proprietário da terra pode aumentar ou diminuir no futuro é uma das marcas mais fundamentais do mercado imobiliário atualmente. Nesse sentido, criase uma série de dinâmicas para que os interesses dos especuladores sejam alcançados.

A incorporação da esfera imobiliária na financeirização da economia estimulou uma modificação não só na captação de renda fundiária, mas também no processo de produção do espaço urbano. A produção da materialidade nas cidades, os investimentos feitos em infraestrutura, moradia, bens culturais, serviços públicos, etc, incorporam valor ao espaço ao urbano, pois se trata de trabalho humano despendido. Com a inserção da financeirização no mercado imobiliário, a produção da cidade passa cada vez mais a ser efetuada em função do valor de troca (CARLOS, 2011), e a opção do que é ou não construído e em qual ponto da cidade ocorrerá melhorias dependerá do potencial de valorização de cada área, a qual passa a ser especulada na bolsa de valores e com emissões de títulos. Com base na nova dinâmica da renda diferencial e no papel da valorização do espaço, a produção da cidade passa a constituir um negócio em si, e não mais apenas um meio para se realizar o lucro criado na indústria:

[...] A compra e venda de fragmentos do espaço urbano tomam a dianteira no rol de estratégias dos setores privados para uma recuperação de taxas de lucro e a cidade contemporânea deixa assim de servir ao capital somente a partir de função de espaço de circulação propício a realização da mais-valia para se tornar, ela mesma, o objeto dessa valorização capitalista, parte do capital empregado no processo de valorização, 
a partir da valorização do espaço. [...] A cidade como negócio superou a condição de cidade como lugar do negócio (SANTOS, 2006, p.111).

Isso ocorre porque qualquer expectativa de investimento maciço feito em determinado fragmento da cidade valorizará este lugar e poderá impactar as rendas fundiárias futuras das propriedades lindeiras e gerar valorização do espaço, estimulando um efeito imediato de aumento dos preços do solo e dos imóveis. Nesse sentido, a especulação imobiliária pode ocorrer por meio da aquisição de imóveis a preços baixos em áreas distantes ou degradadas da cidade, de modo que a venda ocorrerá quando surgir possibilidade de investimentos próximos a esses imóveis e terrenos.

Em razão da possibilidade de valorização do espaço e aumento das rendas futuras, passou a ser rentável para consórcios de empresas investirem em fragmentos das cidades, seja com construções novas ou requalificações de áreas degradas. Muitas vezes, essas mesmas empresas são detentoras de terrenos próximos aos seus investimentos ou os adquirem por permuta com o poder público. Assim, a partir das décadas de 80 e 90, os governos das cidades, com menores alternativas de receitas diante do contexto de crise, passaram a estabelecer parcerias público-privadas para intervenções urbanas em fragmentos específicos da cidade. Tratam-se dos projetos urbanos com base no planejamento estratégico, nos quais os setores privados normalmente são beneficiados pela valorização que em grande parte é produzida pelo trabalho de toda a sociedade, por meio do Estado. Esses projetos atualmente assumem a forma de operações urbanas, concessões urbanísticas, "revitalizações" de áreas degradadas, etc. O planejamento estratégico surge como forma de intervenção urbanística adequada ao momento de crise do capital e de emergência do regime de acumulação flexível. O planejamento estratégico ou mercadológico

representa a adoção de políticas neoliberais no plano da cidade; perde-se a perspectiva
da regulamentação da cidade, para buscar intervenções em fragmentos estratégicos,
desconsiderando que estes acabam por interferir na dinâmica de
valorização/desvalorização [...] (ALVAREZ, 2013, p.119.).

Esse novo tipo de distribuição de investimentos nas cidades acaba, na maioria dos casos, produzindo maior disparidade entre os fragmentos urbanos, contribuindo para a criação de ilhas de prosperidade num mar de péssimas condições de vida urbana. O processo de fragmentação da cidade se intensifica, bem como a segregação intraurbana:

O mecanismo de valorização capitalista que passa pelo imobiliário conta com a disponibilização recorrente de espaços para investimentos que, por uma somatória de fatores como custos, rentabilidade e riscos, recai sempre sobre um território restrito da cidade (SANTOS, 2006, p. 120). 
Os operários, trabalhadores e desempregados, que tinham vilas próprias projetadas no urbanismo modernista, neste novo momento em algumas oportunidades não são sequer lembrados nos projetos urbanísticos. Quando eles são moradores dos locais eleitos para serem "revitalizados" pelas parcerias público-privadas, via de regra são expulsos do lugar, ora de modo direto, pela remoção por meio da polícia - quando não possuem a posse legal da terra -, ora pela dinâmica de mercado, que os força a sair da moradia pela enorme valorização dos terrenos e imóveis.

Essa mudança de contexto teve impacto não apenas no planejamento urbano e no urbanismo, a própria governança das cidades foi modificada. Harvey (1989) identifica que até a década de 1960, a abordagem da gestão urbana era eminentemente administrativa, pois as localidades e municipalidades pensavam o território como um todo e escolhiam a distribuição dos recursos públicos de modo a manter um equilíbrio. A partir da década de 70 , sobretudo desde a crise de 73, mudou-se o foco da governança urbana para o que Harvey qualificou de empreendedorismo. Isso significou que a partir de então os governos locais eram os entes que deveriam tomar a iniciativa de buscar recursos para o investimento nas cidades. Dessa forma, houve um grande incentivo à delegação da gestão de áreas urbanas ao setor privado, bem como às parcerias público privadas (HARVEY, 1989). Nesse mesmo movimento, houve a abertura de canais participativos em âmbito estatal para legitimar essa delegação de poderes do poder público aos cidadãos. Com isso, coloca-se a questão da apropriação da autonomia local das cidades como um expediente do capital para legitimar as políticas empreendedoras urbanas. Assim, a ênfase na necessidade de participação popular nas decisões de governo nem sempre redundam em políticas urbanas mais progressistas.

A emergência do discurso de participação no Brasil ocorre juntamente com a terceira onda de democratização e o declínio das noções de planejamento burocrático centralizado, em detrimento de uma lógica de flexibilidade e valorização do local. Por esse motivo, muitas vezes o discurso da abertura de canais participativos veio acompanhado de medidas para descentralizar a gestão pública. A ideia de cidadania passou a ganhar vulto, com o pressuposto de que os cidadãos individualmente, e não mais em corporações ou classes, decidiam os rumos políticos da cidade ou dos países.

Sobre o conceito de participação, Lavalle et al. (2011) afirmam que:

\footnotetext{
" Participação" é, a um só tempo, categoria nativa da prática política de atores sociais, categoria teórica da teoria democrática com pesos variáveis segundo as vertentes teóricas e os autores, e procedimento institucionalizado com funções delimitadas por leis e disposições regimentais. A multidimensionalidade ou polissemia dos sentidos
} 
práticos, teóricos e institucionais torna a participação um conceito fugidio, e as tentativas de definir seu valor ou seus efeitos, escorregadias. Não apenas em decorrência da diversidade de expectativas nela depositadas e de que a aferição de efeitos é operação sabidamente complexa, mas devido ao fato de sequer existirem consensos quanto aos efeitos esperáveis da participação, ou, pior, quanto à relevância de avaliá-la por seus efeitos. Afinal, ponderar o valor da participação pela sua utilidade equivale a desvalorizá-la ou torná-la secundária em relação ao efeito almejado.

A proposta nessa investigação é realizar a investigação da participação popular enquanto prática política que amplie o componente deliberativo dos agentes políticos, ou ainda que permita formas de representação extraparlamentar.

Em parte, a incorporação da participação popular nas instituições veio como resposta ao declínio da confiança na democracia representativa, sobretudo nos países em que ela já estava mais plenamente estabelecida, como aqueles da Europa Ocidental e os Estados Unidos. O distanciamento dos cidadãos com seus representantes eleitos faz com que a proporção de eleitores tenha uma tendência a queda. A abertura de canais populares é uma estratégia importante para tentar retomar parte da confiança dos cidadãos na democracia, bem como estabelecer novos meios de controle dos governantes.

Países que saíram de regimes autoritários entre nas últimas três décadas do século XX, como o Brasil, também incorporaram em suas legislações instrumentos de participação popular na administração pública e na gestão das cidades. No Brasil, o discurso da descentralização e participação popular na administração pública e urbana tornam-se mais frequentes a partir dos anos 1980, influenciando alguns dos itens da Constituição de 1988. Especificamente sobre a gestão urbana, o Estatuto das Cidades regulamentou a participação popular na elaboração de instrumentos de planejamento como o Plano Diretor Estratégico. A significativa atuação de associações civis, movimentos sociais urbanos, sindicatos e outros tipos de núcleos de organização popular na década de 80 foi decisiva para que houvesse institucionalização de canais diretos de participação nos governos.

Apesar do crescente aumento dos discursos e práticas de incorporação da sociedade civil na gestão do Estado, há experiências e estudos que revelam que nem todos os cidadãos possuem condições iguais de participação. O nível de formação educacional, a condição econômica e as experiências comunitárias pregressas são fatores que deixam cidadãos em condição de desigualdade de acesso a instâncias participativas. Desse modo, a própria geografia da cidade pode revelar essa desigualdade de condições de participação, por exemplo, através da constatação de bairros com graus e qualidade de participação mais efetiva do que outros. Há 
ainda estudos que apontam que quanto piores as condições de acesso à cidade, maior é a possibilidade de participação. Ao analisar a experiência do Orçamento Participativo na cidade de Porto Alegre - um exemplo importante de participação política institucionalizada Lahorgue (2004) comenta que as camadas mais pobres da população participaram em maior proporção das assembleias por regiões em razão da necessidade de solução de carências mais imediatas dos habitantes.

Por um lado, pode-se imaginar associações civis, sindicatos, movimentos sociais e partidos políticos sendo cooptados por meio da institucionalização da participação. Desse modo, tornar-se-iam menos combativos na medida em que houvesse concessões mais recorrentes a algumas reivindicações mais modestas e, principalmente, incorporação de indivíduos que participam na estrutura institucional, como a negociação de concessão futura de cargos comissionados a participantes de conselhos, por exemplo. Além disso, é possível que a participação popular ocorra apenas do ponto de vista formal, sem poder efetivo às instâncias assim constituídas, de maneira a criar mais legitimidade aos administradores públicos sem a devida contrapartida de cumprimento das demandas trazidas pelos cidadãos. Nesse sentido, uma outra crítica sobre a participação popular em instâncias estatais é o fato dela poder ser usada apenas para legitimar políticas públicas que já estavam programadas pelos governantes, pois mesmo que tal política fosse rechaçada pelos cidadãos nessas instâncias, o governo pode dizer que houve a consulta popular antes de implementar determinada política pública.

Por outro lado, a participação popular institucionalizada produz uma rotina de fiscalização do poder público, exige o aprimoramento de mecanismos de transparência e mantém uma pressão constante sobre os governantes e administradores em relação ao cumprimento de políticas públicas. Cria-se um aprendizado que desloca o debate político da arena estritamente partidária das campanhas políticas. Lahorgue (2004) afirma que esse instrumento tem como potencialidade a politização de questões normalmente vista como técnica e a dissolução da representação política tradicional, no entanto há possibilidade de não se transformar em poder autônomo pela irregularidade da participação e as tentativas de imposição de obras prioritárias pelos governos, naquele caso a prefeitura de Porto Alegre.

Esse breve panorama da problemática envolvendo as cidades, o planejamento e a participação popular coloca como questão a possibilidade ou impossibilidade de se produzir uma outra geografia urbana por meio da abertura de canais participativos institucionais. Antes de analisar o processo de participação política nos conselhos participativos das prefeituras 
regionais de São Paulo, cabe verificar sob quais condições se implementou a descentralização administrativa na capital paulista, elemento fundamental para a compreensão do modelo de participação por região. 


\subsection{Gestão urbana descentralizada e a implementação das prefeituras regionais no Município de São Paulo}

\subsubsection{Experiências de descentralização política-administrativa do Município de São Paulo}

Embora as prefeituras regionais sejam órgãos instalados recentemente, houve experiências anteriores de gestões descentralizadas no Município de São Paulo. Os primeiros subprefeitos da capital paulista foram instituídos em 1907, no início do período republicano. Segundo a legislação estadual da época, seria eleito um subprefeito por distrito de paz na Unidade Federativa, com exceção do distrito da sede dos municípios, o qual seria de jurisdição apenas do prefeito. Além dos subprefeitos, previa-se em lei a eleição de juízes de paz, os quais eram encarregados de resolver conflitos locais e efetuar os registros civis básicos como nascimentos, casamentos e óbitos. Aos subprefeitos cabia a execução de serviços locais, a fiscalização de leis, a solicitação de demandas locais e de receitas ao prefeito ${ }^{5}$.

Cabe ressaltar que neste período os distritos de paz circunscreviam os diferentes núcleos urbanos que compunham os municípios, sendo esses núcleos compreendidos como áreas que possuíam rarefeita conexão com a sede da cidade, tais como núcleos de áreas rurais, bairros distantes do centro da cidade, subúrbios, etc. Segundo a lei, metade dos impostos arrecadados nos distritos de paz com subprefeitos deveriam necessariamente ser revertidos para estas áreas, o que mostra um substancial grau de autonomia financeira, ao menos legalmente (SÃO PAULO [Estado]; Decreto n $\left.{ }^{\circ} 1.454 ; 1907\right)$.

Apesar de subprefeitos estarem previstos nos municípios paulistas desde 1907, a primeira subprefeitura do Município de São Paulo foi instalada em 1935, ano em que o Município de Santo Amaro foi anexado à capital paulista, ficando a partir de então com o estatuto de subprefeitura - embora a lei não explicitasse as funções desse novo órgão ${ }^{6}$. Supõese que no período de governo de Getúlio Vargas, entre 1930 e 1945, não tenham ocorrido eleições de subprefeitos, pois neste período praticamente não houve eleições diretas no país

\footnotetext{
${ }^{5}$ A criação dos subprefeitos consta no Decreto n ${ }^{\circ}$ 1.454, de 5 e abril de 1907 (SÃO PAULO [Estado], 1907), que regulamenta a organização dos municípios do Estado de São Paulo, estabelecendo, entre outros aspectos, os componentes da administração municipal: prefeitos, vereadores e subprefeitos.

${ }^{6}$ Santo Amaro era município e foi anexado à capital paulista em 1935, na condição de subprefeitura (SÃO PAULO [Município], Decreto $n^{\circ} 6.983$, de 22 de fevereiro de 1935). Tratava-se de um estatuto especial concedido apenas a essa circunscrição, na medida em que originalmente os subprefeitos exerciam jurisdição nos distritos de paz. Formalmente, tal condição só muda na capital paulista em 1956.
} 
(TSE, 2014).

A partir de 1947, após regulamentações na organização municipal exigida pela Constituição Federal de 1946, permaneciam existindo os cargos de subprefeitos para administrar os distritos, tal como estabelecido desde o início da República Velha. No entanto, segundo a legislação: "salvo os distritos de paz da sede, todos os demais serão administrados por subprefeitos, diretamente subordinados ao prefeito do município e nomeados por este, com aprovação da Câmara"’7. Assim, perdeu-se definitivamente a elegibilidade dos subprefeitos. Nesta regulamentação não são citadas vinculações orçamentárias entre a arrecadação de impostos nos distritos e a obrigatoriedade de gastos nos mesmos.

Em 1956, o então prefeito paulistano Toledo Piza decretou a criação de 19 subprefeituras $^{8}$, que foram somadas a já existente Subprefeitura de Santo Amaro ${ }^{9}$. Tratou-se de uma medida de descentralização administrativa, que atribuía aos subprefeitos tarefas como fiscalização, gerenciamento de serviços e obras locais e elaboração de propostas de melhorias aos prefeitos. O decreto, indiretamente, mostra que, ao menos no Município de São Paulo, os subprefeitos deixam de exercer jurisdição nos distritos, pois se cria um novo recorte territorial para isso - a subprefeitura. A descrição dos limites das subprefeituras presente na lei explicita que essas divisões territoriais não eram formadas por agregação de distritos e subdistritos, sendo, no geral, incompatíveis com essas divisões. Todavia, as subprefeituras estavam em consonância com o embasamento da legislação estadual da época (SÃO PAULO [Estado]; Lei $\mathrm{n}^{\mathrm{o}} 1$; 1947), pois todos os distritos estavam contemplados com subprefeitos, mesmo que houvesse casos em que o mesmo subprefeito administrasse mais de um distrito, como na Subprefeitura de Perus - composta pelos distritos de Perus e Jaraguá.

Segundo Sposati (2001), essa medida de descentralização administrativa, bem como outras que viriam, tentariam adaptar a administração pública à nova realidade da capital paulista, decorrente do crescimento industrial acelerado na década de 1940 e 50 e do consequente aumento populacional, da complexificação da divisão social do trabalho e do surgimento de demandas sociais da classe trabalhadora:

O grande crescimento territorial verificado nesse período, com a expansão estrondosa das periferias em todas as direções, inflou rapidamente o território urbano,

\footnotetext{
${ }^{7}$ São Paulo (Estado), Lei no 1, de 18 de setembro de 1947, Art.53.

8 São Paulo (Município), Decreto no 3.270, de 29 de setembro de 1956.

9 As subprefeituras eram as seguintes: Brás, Moóca, Penha, Tatuapé, Vila Prudente, Ipiranga, Vila Mariana, Indianópolis, Pinheiros, Lapa, Nossa Senhora do Ó, Santana, Vila Maria, São Miguel, Itaquera, Guaianazes, Osasco, Perus e Tucuruvi.
} 
aumentando ainda mais a defasagem entre a quase cidade real e os parâmetros de cidade utilizados pelas instituições, companhias e serviços públicos, autoridades e órgãos de gestão urbana. A inclusão de novas demandas e novas repostas na pauta do governo municipal ocorreu, porém, de forma fragmentada e pouco planejada (SPOSATI, 2001, p.68).

De qualquer modo, percebe-se que esse período é o momento em que as divisões territoriais intramunicipais estabelecidas pelo Estado são prioritariamente concebidas para a racionalização administrativa. Isso é feito por meio de regionalizações, sejam elas elaboradas para todo o âmbito municipal, sejam elas elaboradas para setores específicos da gestão pública. Obviamente, a descentralização administrativa acompanhada pelas respectivas regionalizações já ocorria em território paulistano, mas agora tais ações seriam intensificadas.

A regionalização básica do município para fim administrativo foi reformulada em 1965, na gestão do prefeito Faria Lima. As subprefeituras foram substituídas ${ }^{10}$ por 7 administrações regionais (ARs, também conhecidas como regionais): Sé, Vila Mariana, Pinheiros, Lapa, Santana, Penha, Moóca ${ }^{11}$. A instituição das ARs foi efetuada:

Considerando que as modernas técnicas recomendam o planejamento centralizado $e$ a execução descentralizada das atividades administrativas de modo a assegurar, com economia de recursos, o atendimento das necessidades públicas; [...] Considerando a necessidade de bem definir as responsabilidades na execução dos serviços e obras públicas [...] (SÃO PAULO [Município], Decreto $\mathrm{n}^{\circ}$ 6.236, de 13 de outubro de 1965, grifo nosso).

A necessidade de "planejamento centralizado e execução descentralizada" expressa claramente o caráter técnico-administrativo da regionalização, pautada principalmente na “execução dos serviços e obras públicas". Isso denota que essa divisão territorial era dotada de menor autonomia que as subprefeituras do governo Toledo Piza, pois nas ARs não havia sequer previsão de elaboração de propostas de planejamento local por parte dos administradores. Maior ainda é a diferença entre as atribuições dos administradores regionais e dos antigos subprefeitos, àqueles que exerciam jurisdição nos distritos, na medida em que os últimos tinham, ao menos formalmente, uma função política mais autônoma e ampla, evidenciada pelo fato de serem eleitos pela população distrital. A lei estadual que regulou a organização dos municípios a partir de $1969^{12}$ tornou obrigatória a condição subalterna desses agentes: "os Subprefeitos e os administradores regionais, como delegados do Executivo, exercerão funções meramente administrativas".

\footnotetext{
${ }^{10}$ Com exceção da Subprefeitura de Santo Amaro, a qual foi mantida até 1972 (SPOSATI, 2001).

${ }^{11}$ São Paulo (Município), Decreto n ${ }^{\circ}$ 6.236, de 13 de outubro de 1965.

${ }^{12}$ São Paulo (Estado), Decreto-Lei Complementar n ${ }^{\circ}$ 9, de 31 de dezembro de 1969, Art.44.
} 
A divisão territorial do município em regionais consolidou-se, embora houvesse algumas variações, pois "cada prefeito de São Paulo estabeleceu o número de administrações regionais e sua importância no processo de governo da cidade", e o número de ARs variou de 7 a 33 entre os diversos prefeitos paulistanos (SPOSATI, 2001, p.74). Entre as variações das ARs, destaca-se uma curta mudança que ocorreu no governo Jânio Quadros, em 1986, que “[...] além de 33 administrações regionais, criou um novo escalão de gestão, através da agregação das administrações regionais sob a supervisão de subprefeituras, o que durou até o período final de sua gestão" (SPOSATI, 2001, p.74). Foram criadas 5 subprefeituras ${ }^{13}$, com o papel de fiscalizar e supervisionar a atuação das administrações regionais, bem como fazer propostas de projetos de melhorias e orçamentárias ao prefeito. Percebe-se que as atribuições do subprefeito descritas na lei aumentam levemente o campo de atuação restrito dos administradores regionais. No ano seguinte, em 1987, as subprefeituras foram reorganizadas e renomeadas como Coordenadorias das Administrações Regionais (CAR) ${ }^{14}$, permanecendo assim até 1989 quando deixaram de existir na prática, pois as ARs passaram a subordinar-se diretamente à Secretaria das Administrações Regionais (SAR).

Há que se destacar que as ARs não foram compatibilizadas com a divisão distrital/subdistrital do município. Segundo Cazzolato (2005, p.17), os perímetros das ARs estavam mais atualizados em relação à dinâmica recente da cidade:

Diferentemente dos Distritos e Subdistritos, as Administrações Regionais guardavam
uma relação mais atual com a cidade, ou seja, suas unidades correspondiam a bairros
que concentravam forte atividade comercial, reforçando-lhes a condição de polos
regionais. A divisão estabelecida pelo município também se diferenciava da estadual
no tocante aos limites, pois estes incidiam sobre os elementos da paisagem urbana
mais recente.

Diante desse problema de compatibilidade de cadastros territoriais, somada à burocratização da gestão pública e às demandas por ampliação da participação dos cidadãos no

\footnotetext{
${ }^{13}$ São Paulo (Município), Lei no 10.089, de 26 de junho de 1986. As subprefeituras eram as seguintes I - Sé (ARs: Sé, Pinheiros e Lapa); II - Vila Maria (ARs: Vila Maria, Santana, Vila Guilherme, Tucuruvi, Freguesia do Ó, Pirituba, Perus e Casa Verde); III - Santo Amaro (ARs: Santo Amaro, Campo Limpo, Butantã, Vila Mariana, Jabaquara, Ipiranga e Capela do Socorro/Parelheiros); IV - Penha (ARs: Penha, Móoca, Sapopemba, Vale do Aricanduva e Vila Prudente) e V - São Miguel Paulista (ARs: São Miguel, Ermelino Matarazzo, Itaquera, Guaianazes, Itaim Paulista e São Mateus)

${ }^{14}$ São Paulo (Município), Decreto n ${ }^{\circ} 25.085$, de 27 de novembro de 1987. As Coordenadorias das Administrações Regionais (CAR) eram as seguintes: I - CAR Zona Centro (ARs: Sé, Vila Mariana, Móoca, Ipiranga, Vila Prudente e Tatuapé); II - CAR Zona Norte (ARs: Vila Maria, Santana, Vila Guilherme, Tucuruvi, Freguesia do Ó, PiritubaJaraguá, Perus e Casa Verde); III - CAR Zona Leste (ARs: Penha, Ermelino Matarazzo, São Miguel Paulista, Itaim Paulista, Guaianazes, Itaquera, Vale do Aricanduva, Sapopemba, São Mateus); IV - CAR Zona Oeste (ARs: Lapa, Butantã, Pinheiros e Campo Limpo) e V - CAR Zona Sul (ARs: Santo Amaro, Jabaquara, Pedreira/Campo Grande, Capão Redondo, Capela do Socorro e Parelheiros).
} 
planejamento urbano, passou-se a considerar uma reestruturação mais profunda do quadro territorial da capital paulista.

A partir dessa breve descrição de modelos de descentralização da gestão pública paulistana, percebe-se que esse tema figura há um longo período na agenda administrativa da cidade. Os níveis de autonomia à descentralização variam em alguma medida conforme os contextos, bem como as atribuições e os nomes que se dão aos órgãos descentralizados. No entanto, a partir da década de 80, com o maior auge de crescimento populacional de São Paulo, esses problemas tornar-se-iam mais sensíveis na pauta municipal, pois constatou-se uma dificuldade cada vez maior de se governar e implementar políticas públicas centralizadas em uma metrópole de dimensões tão expressivas.

\subsubsection{Redemocratização, autonomia municipal e novas tendências de gestão pública}

O fim da década de 1980 no Brasil foi marcado pelo término da ditadura militar que vigorou no país desde 1964. A abertura política ocorreu de maneira gradativa desde o fim da década de 70 e só foi plenamente concluída em 1988, com a promulgação de uma nova constituição. Nesse contexto, foi decisiva a participação de setores da sociedade civil e movimentos sociais nas mobilizações para retomada da democracia e aumento dos direitos sociais (DÓRIA, 1992). Muitos protagonistas das grandes mobilizações para a retomada da democracia ascenderam ao poder, tanto no legislativo quanto no executivo. Este é um dos motivos pelos quais a Constituição de 1988 apresenta instrumentos de consolidação da democracia e consideráveis avanços nos direitos sociais quando comparada às constituições anteriores.

A necessidade de aprimorar a democracia e construir possibilidades de descentralização política e administrativa fez-se presente na Carta Magna de 1988 por meio de uma reorganização do sistema político do país. Houve uma descentralização política levada a cabo com a redistribuição dos poderes entre executivo e legislativo, pois no período ditatorial o Congresso e o poder legislativo perdera significativa importância. Do ponto de vista territorial, destacaram-se a atuação dos movimentos municipalistas na Assembleia Constituinte. Segundo Dória (1992, p.60), havia duas principais vertentes desse movimento:

Um deles foi o formado pelas diversas frentes municipalistas, de prefeitos e outras lideranças políticas, empenhadas essencialmente na mudança das leis tributárias para a redistribuição dos recursos estatais e a eliminação dos mecanismos políticos de controle no repasse de verbas da União e dos estados para os municípios. O outro 
derivou dos movimentos urbanos reorganizados nos anos 85 e 86 com vistas a agir nos níveis políticos mais elevados e colocar na Constituição normas de justiça social no acesso dos cidadãos as cidades.

Segundo o autor, essas duas frentes foram parcialmente vitoriosas. A primeira por conta da aprovação da revisão tributária que aumentava os recursos municipais, por meio de arrecadação de impostos próprios e repasses de verbas mais expressivos da União e dos estados, e a segunda por dispositivos incluídos na Constituição tal qual o plano diretor das cidades, que prevê a participação popular.

Pelo texto constitucional, os municípios tornaram-se entes da federação, assim como os estados, desse modo os mesmos passaram a ter legislação própria pautada em lei orgânica ${ }^{15}$. Em consequência de ter o estatuto de unidade federativa:

[...] o município brasileiro pode relacionar-se diretamente, como entidade política autônoma, com qualquer uma das outras ordens [federativas] [...]. Em decorrência, qualquer município brasileiro pode fazer acordos externos (desde que autorizado pela União), criar hinos, bandeiras, armas, selos municipais e executar suas funções livremente (CIGOLINI, 2009, p.180).

A concessão da competência de "criar, organizar e suprimir" distritos ${ }^{16}$ também foi consequência do crescimento da autonomia dos municípios. Antes de 1988, a legislação territorial paulista dava aos mesmos a prerrogativa de dividir seu território para fins estritamente administrativos, entretanto, era vedada à esfera municipal a reorganização dos distritos, tarefa que era exclusiva do estado. Não há na Constituição ou em leis federais atuais menção à necessidade de existência prévia de distritos para ocorrer emancipações, como já houve anteriormente, mas a legislação territorial vigente no Estado de São Paulo mantém em seu texto a necessidade da existência prévia de um distrito como condição da área a ser emancipada ${ }^{17}$, portanto essa divisão territorial transcende a questão estritamente administrativa.

O crescimento da importância do município no país, decorrente do aumento de sua autonomia política, administrativa e financeira, estimulou o surgimento de um significativo número de emancipações nos anos posteriores à promulgação da Constituição de 1988. Parte da enorme quantidade de municípios criados nessa época são atribuídos também à flexibilização das leis territoriais após o fim do período ditatorial, no qual as emancipações foram muito dificultadas. O expressivo número de novos municípios passou a ser preocupante para alguns

\footnotetext{
${ }^{15}$ Brasil, Constituição (1988), Art. $1^{\circ}$ e 29.

${ }^{16}$ Brasil, Constituição (1988), Art. 30, IV.

${ }^{17}$ O quadro normativo atual da criação de municípios e distritos em São Paulo encontra-se na Constituição estadual (SÃO PAULO [Estado], Constituição, 1989) e em Lei Complementar (SÃO PAULO [Estado], Lei Complementar $\left.\mathrm{n}^{\circ} 651,1990\right)$.
} 
setores políticos do país em meados da década de 90 , num contexto de corte de gastos e ajustes fiscais ${ }^{18}$. Isso levou a elaboração da Emenda Constitucional $n^{\circ} 15$ de 1996, que submeteu a criação de municípios ao Estudo de Viabilidade Municipal. Dessa forma, a partir de 1996 o processo de criação de municípios foi radicalmente reduzido. Segundo Cigolini (2009), 1.465 municípios foram criados entre 1988 e 2008, dos quais apenas 57 após a referida emenda constitucional - sendo esses últimos criados por decisão judicial. Ainda não houve aprovação de lei complementar que regulamente o Estudo de Viabilidade Municipal e, consequentemente, os critérios de emancipação. Portanto, a criação de novos municípios segue sendo muito restrita.

A questão das emancipações ilustra a centralidade da busca por autonomia na redemocratização do país e a relação dessa demanda com as redefinições de divisões territoriais. Essas reestruturações foram motivadas também por uma tendência de renovação nos paradigmas da administração pública, acompanhando o sentido de descentralização política que ocorria no país. Dessa forma, passou a ser comum a demanda por uma administração pública menos burocratizada, ou seja, que cumprisse os objetivos de gestão de uma forma mais ágil, com menor número de etapas e intermediações entre os processos e que partisse de decisões menos centralizadas.

A crítica à administração burocrática teve origem, por um lado, em práticas administrativas de empresas que buscavam maior eficiência nos seus processos para baixar custos e maximizar os lucros, seguindo a tendência das reestruturações do capitalismo a partir da década de 1970. Partidários das novas tendências de administração empresarial defendiam a ideia de que a gestão pública deveria se adequar às novas práticas, tornar-se mais eficiente, cortar gastos e fazer parcerias com o setor privado. Ou seja, tratava-se de sugerir ao Estado a adoção das novas práticas administrativas empresariais (FINATEC, 2004). Por outro lado, houve críticos ao paradigma burocrático de administração estatal que discordavam da adoção das práticas empresariais como solução ao problema. Tratava-se de setores predominantemente populares que reivindicavam uma maior participação dos cidadãos e de movimentos sociais no processo de planejamento e gestão estatal (FINATEC, 2004). Não se tratava de modificar a administração pública para aumentar sua eficiência, tal como na linguagem empresarial, mas sim de melhorar os canais de participação popular na gestão pública, democratizando-a.

\footnotetext{
18 Cigolini (2009) analisa em detalhes a posição de diversos autores que discorreram sobre o alto número de emancipações do início da década de 90. A principal clivagem está entre os que defendem as emancipações, por motivos como a distribuição de recursos e a afirmação da autonomia local, e os que condenam as emancipações, por motivos como o desequilíbrio fiscal e a possibilidade de criação de redutos eleitorais.
} 
Nesse sentido, o paradigma burocrático de administração entrou em crise e era criticado por posições políticas muito diferentes. A necessidade de reformulação nas concepções de gestão pública, portanto, apareceram na renovação das legislações federais, estaduais e municipais no período de redemocratização e tais modificações também estimularam reestruturações nas divisões territoriais. Foi essa crítica que resultou nos novos projetos de criação de subprefeituras no Município de São Paulo no início da década de 1990. Portanto, o contexto da redemocratização do país fez emergir duas determinações fundamentais que induziram alterações normativas sobre as divisões territoriais: uma política, pautada na exigência de maior descentralização, autonomia e poder local; e uma administrativa, a partir das demandas de desburocratização, descentralização da gestão e participação popular no planejamento estatal.

Essas necessidades ficaram expressas na Lei Orgânica do Município de São Paulo, de 1990, por meio da indicação de adoção de mecanismos de descentralização política e racionalização administrativa. A previsão na Lei Orgânica municipal da criação dos conselhos de representantes, instância formada pela eleição de representantes locais, exemplifica uma iniciativa de estímulo à participação popular na gestão municipal, em tarefas como a participação no planejamento local e a fiscalização da administração pública. Na perspectiva da divisão territorial, destacam-se a diretriz de adoção dos distritos enquanto base da organização dos serviços públicos municipais e a previsão de implantação das subprefeituras como órgãos de administração municipal de nível local ${ }^{19}$. Entre essas três diretrizes citadas, a primeira a ser aplicada foi a reorganização da divisão distrital do município em 1992, em perspectivas substancialmente diferentes do padrão estabelecido nas divisões anteriores. Dessa forma:

São Paulo foi a primeira cidade, pós-Constituição de 1988, a exercer o direito de realizar o próprio tratamento intraurbano. Não se tratava mais de o Estado simplesmente ditar a organização interna do município, mas de este assumi-la como de seu peculiar interesse do ponto de vista da questão socioterritorial e da sistematização de informações urbanas. Mais ainda, o processo desencadeado em São Paulo abriu as portas, antes cerradas, ao debate público quanto à divisão territorial a adotar (SPOSATI, 2001, p.35).

A reelaboração da divisão distrital, proposta pelo governo executivo municipal da época - gestão Luíza Erundina - justificou-se oficialmente pela necessidade de atualização de uma divisão regional para a cidade, pois as existentes na época, segundo os proponentes da lei, já

${ }^{19}$ São Paulo (Município), Lei Orgânica do Município de São Paulo, 1990. 
não refletiam mais o quadro territorial do município. Justificou-se também pelo apoio à descentralização da gestão, para servir de base de coleta e divulgação de dados socioeconômicos e pela necessidade de se estabelecer uma divisão territorial que unificasse os cadastros territoriais para a administração pública do município.

\section{Mapa 1 - Distritos do Município de São Paulo a partir de 1992}

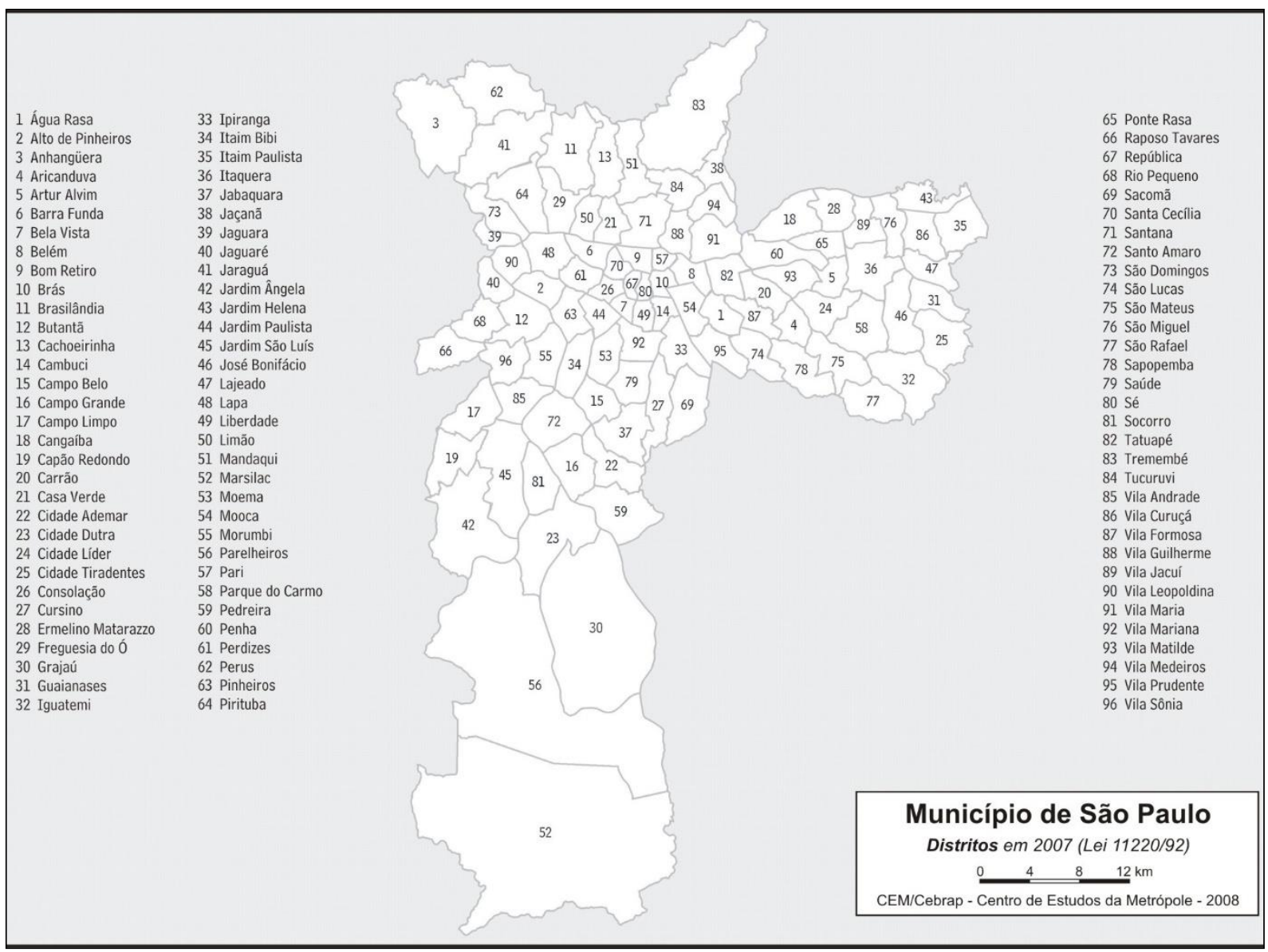

Extraído de: Centro de Estudos da Metrópole (2007).

Fontes: São Paulo (Município) (Projeto de Lei nº 184, 1990; Lei nº 11.220, 1992).

\subsubsection{A implementação das prefeituras regionais no Município de São Paulo}

A reorganização dos distritos da capital paulista em 1992 foi o precedente fundamental para a implementação das subprefeituras, pois objetivou-se a unificação dos cadastros territoriais do município e propunha-se uma base referencial para a descentralização político- 
administrativa. Além disso, os distritos constituem as unidades de agregação para a formação das subprefeituras. O governo da época e seus apoiadores julgaram que a unificação de cadastros - até então tido como caótico por certos gestores da cidade - era passo fundamental para viabilizar a descentralização do planejamento, da administração e a participação popular na gestão pública do município. A nova divisão distrital não foi suficiente para alcançar a descentralização pretendida ou a unificação total dos cadastros, no entanto essa regionalização tornou-se paradigmática para a cidade.

A função para a qual a divisão distrital foi designada na Lei Orgânica o Município de São Paulo sugere uma mudança de significado dessa categoria territorial no âmbito municipal: “O Município instituirá a divisão geográfica de sua área em distritos, a serem adotados como base para a organização da prestação dos diferentes serviços públicos" ${ }^{20}$. Até então, a definição dos distritos não tinha o caráter primordial de ser base para organização de serviços públicos municipais. Esse tipo de uso ocorria, mas era secundário, na medida em que a criação de um distrito significava essencialmente o reconhecimento da relevância de um núcleo de ocupação não contíguo à sede da cidade, ou com conexão recente ou rarefeita com esta ${ }^{21}$. Contudo, os representantes do município optaram por regulamentar a autonomia que a Constituição Federal concedeu às municipalidades, permitindo-as elaborar uma divisão distrital própria, e destacaram uma nova função aos distritos, que tradicionalmente não era fundamental a esse recorte territorial: servir como base referencial para a administração pública.

No momento em que a Lei Orgânica paulistana foi promulgada, a malha territorial do município era múltipla, complexa e desconexa. Esse diagnóstico está presente na exposição de motivos do projeto de lei dos novos distritos, de autoria da prefeita Luiza Erundina, do PT (Partido dos Trabalhadores) $^{22}$ :

A atual organização territorial, incluindo Distritos e Subdistritos, apresenta, com efeito, um quadro caótico com divisões que se superpõem, tais como Administrações Regionais, Setores Fiscais, Setores Postais, Distritos e Subdistritos, Zonas Eleitorais, Distritos Policiais, etc. Divisões essas que coexistem de modo desordenado, sem

\footnotetext{
${ }^{20}$ São Paulo (Município), Lei Orgânica do Município de São Paulo (1990), Art. 157, grifo nosso.

${ }^{21}$ Não por acaso, o número de distritos em São Paulo entre 1985 e 1992 - ano da reorganização da malha territorial - era de apenas 11. A maioria deles eram núcleos de ocupação mais distantes da sede do município ou com ocupação incipiente à época, considerados pela legislação como "vilas": Perus, Jaraguá, Parelheiros, Ermelino Matarazzo, São Miguel Paulista, Itaim Paulista, Itaquera Guaianases, Sapopemba e São Mateus. O distrito sede (São Paulo) era subdividido em 48 subdistritos, estes sim mais adequados a servir de base de referência para o planejamento municipal e para a coleta de estatísticas (SÃO PAULO [Estado], Lei no 8.092, 1964; Lei nº 2.343, 1980; Lei no 4.954, 1985).

22 A prefeita Luíza Erundina exerceu mandato entre 1989 e 1992 em São Paulo.
} 
nenhuma correlação entre si, seja quanto ao número e denominações, seja no traçado de seus limites ${ }^{23}$.

A incompatibilidade dos dados cadastrais e da malha territorial do município passou a ser motivo de preocupação para a administração pública no fim da década de 1980. Como se percebe, além das compartimentações do município em distritos, subdistritos e administrações regionais, havia numerosas divisões territoriais elaboradas para finalidades específicas de setores da administração setorial, como aquelas efetuadas por secretarias ou empresas públicas que gerenciavam serviços, bem como regionalizações da justiça e da polícia. Parte desse panorama pode ser observado pelo Quadro 2 (p.40) O governo da prefeita Luiza Erundina, iniciado em 1989, - primeiro governo paulistano eleito na vigência da nova Constituição - foi o responsável por buscar uma nova base territorial para o município, que passasse a ser o quadro básico a partir da qual as outras divisões teriam que ser compatibilizadas.

O plano do referido governo para a reorganização territorial de São Paulo consistia em duas ações complementares: a definição de uma malha territorial mais atual, por meio da delimitação de novos limites distritais, e a uma reestruturação da gestão regional da cidade, à época representada pelas ARs, que deveria ser reformulada tanto em seu perímetro espacial quanto nas suas funções administrativas (PMSP - SAR, 1991 ${ }^{24}$ ). Segundo as intenções da prefeitura, a redefinição da divisão distrital tinha como propósitos fundamentais a compatibilização dos cadastros administrativos, como parte da racionalização e modernização da gestão da cidade, e a simplificação das referências territoriais do município para a população. Ou seja, além da preocupação com os problemas administrativos gerados pela falta de comunicação das secretarias em nível territorial, a ideia original da redefinição dos distritos tinha como intenção facilitar a participação popular no planejamento da cidade. Isso ocorreria pelo fato de que a os novos distritos seriam unidades territoriais mais fáceis de serem identificadas pelos cidadãos:

A divisão territorial deve ser única, para que todos os organismos atuantes na cidade de São Paulo possam obter e intercambiar dados coletados; o governo municipal possa atuar e a população tenha, na unicidade territorial, melhores condições de se identificar com o município, exercendo, com mais plenitude sua cidadania (PMSP SAR, 1991).

\footnotetext{
${ }^{23}$ São Paulo (Município), Exposição de Motivos, Projeto de Lei no 184/1990, p.1.

${ }^{24}$ A Nova Territorialização do Município de São Paulo (PMSP-SAR, 1991) foi uma compilação de discussões e dados realizada pela antiga Secretaria das Administrações Regionais para fazer o projeto da nova divisão distrital paulistana. Além de textos base sobre temas como a regionalização, nessa publicação há descrição do plano de trabalho da equipe que elaborou a proposta dos novos distritos, os critérios utilizados, as instituições consultadas e diversos anexos, como mapas de regionalizações.
} 
Outro objetivo fundamental da nova divisão distrital seria unificar as áreas de agregação do município para fins estatísticos. Assim, os dados estatísticos passariam a ter como unidade fundamental os novos distritos, e não mais subdistritos, distritos e administrações regionais, de modo que a nova divisão distrital seria compatível aos Setores Censitários do IBGE - as menores áreas de coleta e divulgação de dados estatísticos oficiais pelo IBGE. Ressalta-se também a necessidade de atualização do quadro territorial do município, haja vista a significativa transformação da cidade que ocorrera nas décadas de 1960, 70 e 80 (CAZZOLATO, 2012).

A tarefa de elaborar uma nova divisão distrital do município ficou sob responsabilidade da Secretaria das Administrações Regionais, comandada na época pela assistente social Aldaíza Sposati, a qual liderava uma equipe que contava com dois geógrafos: Josefina Leo Ballanotti e José Donizete Cazzolato. Não por acaso Sposati e Cazzolato estão entre os poucos autores que publicaram trabalhos analisando em detalhes as divisões territoriais paulistanas. Sposati (2001, p.29) afirma que a reestruturação foi feita "por meio de múltiplas discussões com especialistas do IBGE, Sabesp, Eletropaulo, Correios, secretarias municipais e estaduais, representantes comunitários e dirigentes de serviços públicos, entre outros”. A autora destaca o fato da participação de representantes de bairros na divisão do território urbano, algo até então inédito. Segundo a Secretaria das Administrações Regionais, os novos distritos deveriam atender aos seguintes propósitos:

- Simplificar e garantir uma divisão territorial única para todos os órgãos e instâncias produtores de serviços públicos, favorecendo sua integração.

- Possibilitar um referencial comum para a coleta, registro e intercâmbio de dados sobre as regiões e sua população.

- Estabelecer limites territoriais de fácil identificação e memorização (grandes rios, avenidas e ferro vias).

- Garantir o máximo equilíbrio da extensão territorial e da densidade populacional entre todas as regiões.

- Definir os limites da região de modo a manter sua heterogeneidade econômica e social.

- Preservar a história, a tradição e as formas de organização dos moradores locais.

- Conservar a presença e a influencia dos centros comerciais e dos serviços urbanos.

- Demarcar as áreas territoriais de modo a permitir a inclusão de novos e futuros distritos.

- Propiciar ao cidadão o reconhecimento do seu território como uma globalidade jurídica, de produção, consumo e de gestão de serviços públicos (PMSP - SAR, 1991)

A nova divisão distrital passou a vigorar em 1992, dois anos após a promulgação da Lei Orgânica Municipal e à apresentação do projeto de lei à câmara municipal, já no último ano da 
gestão Erundina. A partir de então São Paulo passou a ter 96 distritos ${ }^{25}$, com a configuração do Mapa 1.

A divisão distrital passou a ser amplamente utilizada para divulgação de dados estatísticos oficiais, inclusive do IBGE, e como base para diversas atividades de planejamento. Nesse sentido, parte do propósito de sua criação foi alcançada, por se constituir numa referência de uso mais difundido pelos agentes públicos e mais próxima da realidade atual da capital paulista. Por outro lado, os distritos não solucionaram completamente a questão dos múltiplos cadastros e divisões territoriais às quais São Paulo está submetida, pois permanecem existindo numerosas divisões territoriais específicas para cada órgão da administração pública, muitas sem nenhuma compatibilização com a divisão distrital. Apesar de a homogeneização da malha territorial paulistana ter sido o principal motivador da redefinição dos distritos, Sposati (2001, p.78), quase dez anos depois da vigência da nova divisão distrital, afirmou que:

Quase nada em São Paulo é relacionado ao distrito, que deveria ser a base referencial unitária para todos os serviços da cidade, e, assim, permitir convergir, a uma mesma base territorial, a compatibilização dos dados da realidade, os interesses e necessidades dos cidadãos que ali vivem.

Ainda durante o governo de Luíza Erundina, tentou-se cumprir em 1991 outra determinação da lei orgânica em relação às divisões territoriais: a implementação das subprefeituras para descentralizar a gestão municipal. O projeto de lei previa a total reorganização da administração pública da capital, instituindo 13 subprefeituras e diminuindo o número de secretarias para apenas 5 , de modo a delegar maior autonomia para as unidades regionais ${ }^{26}$. Contudo, o projeto de lei efetuado pela prefeitura não foi aprovado na Câmara Municipal nesta gestão (SPOSATI, 2001; FINATEC, 2004), devido entre outros fatores a dificuldade do governo Erundina de compor maioria na Câmara Municipal (GRIN, 2015). No decorrer da década de 90 e início dos anos 2000, houve numerosos projetos de lei para implementação das subprefeituras, mas todos eles não foram aprovados - além de não terem sido elaborados pelo poder executivo. Dessa forma, o projeto original da gestão Erundina de reformular simultaneamente a divisão distrital e a instância de descentralização regional do município não foi plenamente concluído, de forma que se manteve a divisão do município em administrações regionais. Segundo Cazzolato (2005), previa-se ainda a subdivisão dos distritos em bairros, ação que até hoje não foi realizada.

\footnotetext{
${ }^{25} \mathrm{O}$ projeto de lei original previa a delimitação de 93 distritos, número que aumentou para 96 na publicação da lei final (SÃO PAULO [Município], Lei nº 11.220, de 20 de maio de 1992).

${ }^{26}$ São Paulo (Município), Projeto de Lei no 234, 1991.
} 
Sposati (2001, p.77) sugere que algumas vezes as administrações regionais corresponderam a interesses de lideranças políticas locais, ao contribuírem para a criação e consolidação de "currais eleitorais" dos mesmos. Durante os governos posteriores à criação dos novos distritos - nas gestões de Paulo Maluf $\left(1993\right.$ - 1996) e Celso Pitta $(1997 \text { - 2000 })^{27}$ intensificaram-se denúncias de irregularidades no funcionamento das regionais, fundamentalmente a cobrança de propinas de comerciantes em benefício dos fiscais de algumas ARs. O escândalo de corrupção ficou conhecido em 1998 como "máfia dos físcais"28. Além disso, nesse mesmo intervalo de tempo, houve denúncias de que as ARs serviam mais para empregar aliados de vereadores e determinados grupos em troca de favorecimento político do que para racionalizar a administração pública. O próprio governo Erundina teria se utilizado desse expediente para fortalecer vereadores petistas e angariar apoio de outros partidos na Câmara Municipal (TEIXEIRA, 2004). Assim, o descrédito das ARs foi um dos principais motivadores da execução do plano de dividir o município em subprefeituras, tal como já estava previsto na Lei Orgânica Municipal.

A divisão do município em subprefeituras não era inédita, conforme discutido anteriormente, tendo existido ao longo da história administrativa de São Paulo pelo menos três experiências concretas de divisões territoriais com esta mesma denominação. A primeira foi a elevação de Santo Amaro à categoria de subprefeitura, assim que o antigo município foi anexado à capital paulista, em 1935. A segunda foi a curta experiência que precedeu às administrações regionais, no governo Toledo Piza em 1958. As subprefeituras foram retomadas em 1986 na gestão do prefeito Jânio Quadros, constituindo superintendências fornadas por agregações de ARs. Entretanto, a crise das administrações regionais e o contexto político ensejaram a elaboração de subprefeituras com autonomia muito maior que as regionais, ao menos formalmente.

As novas subprefeituras foram implantadas no governo da prefeita Marta Suplicy (2001 - 2004), do PT, em $2002^{29}$ e passaram a ter grande importância na estrutura administrativa paulistana, com um nível de influência similar ao das secretarias municipais. Trata-se de uma

\footnotetext{
${ }^{27}$ Maluf foi eleito pelo Partido Democrático Social (PDS), legenda que foi reorganizada no Partido Progressista Brasileiro (PPB) em 1993. Pitta, padrinho político de Maluf, foi eleito já pelo PPB.

28 GLOBO. Escândalo da máfia dos fiscais. Memória Globo. Disponível em: <http://memoriaglobo.globo.com/programas/jornalismo/coberturas/mafia-dos-fiscais/primeira-acusacao.htm〉. Acesso em: 25 jan. 2016.

${ }^{29}$ São Paulo (Município), Lei n ${ }^{\circ} 13.399$, de $1^{\circ}$ de agosto de 2002.
} 
alteração significativa da estratégia de descentralização municipal, pois as ARs eram estruturadas de maneira bem menos autônoma:

Os administradores regionais saíram dos distritos de obras, primeira grande divisão territorial da cidade, com função de cuidar apenas da zeladoria de sua região. Suas atividades restringiam-se à prestação de serviços de rotina (limpeza), físcalização das normas municipais e levantamento periódico dos problemas locais urgentes. As ARs eram executoras sem poderes para planejar e definir o destino das verbas disponíveis, restringindo-se apenas a uma divisão territorial para a realização de tarefas (FINATEC, 2004, p.36).

A divisão da capital paulista em subprefeituras foi compatibilizada aos novos distritos, de modo a constituir uma agregação desses. Cabe às subprefeituras a elaboração do planejamento local integrado, de maneira a superar a excessiva departamentalização existente no modelo das secretarias (FINATEC, 2004). Os distritos compõem os arranjos territoriais a partir dos quais esses planos são criados, por isso essas duas divisões territoriais estão intimamente interligadas. O Mapa 2 a seguir mostra as áreas de cada subprefeitura:

Mapa 2 - Subprefeituras do Município de São Paulo a partir de 2002

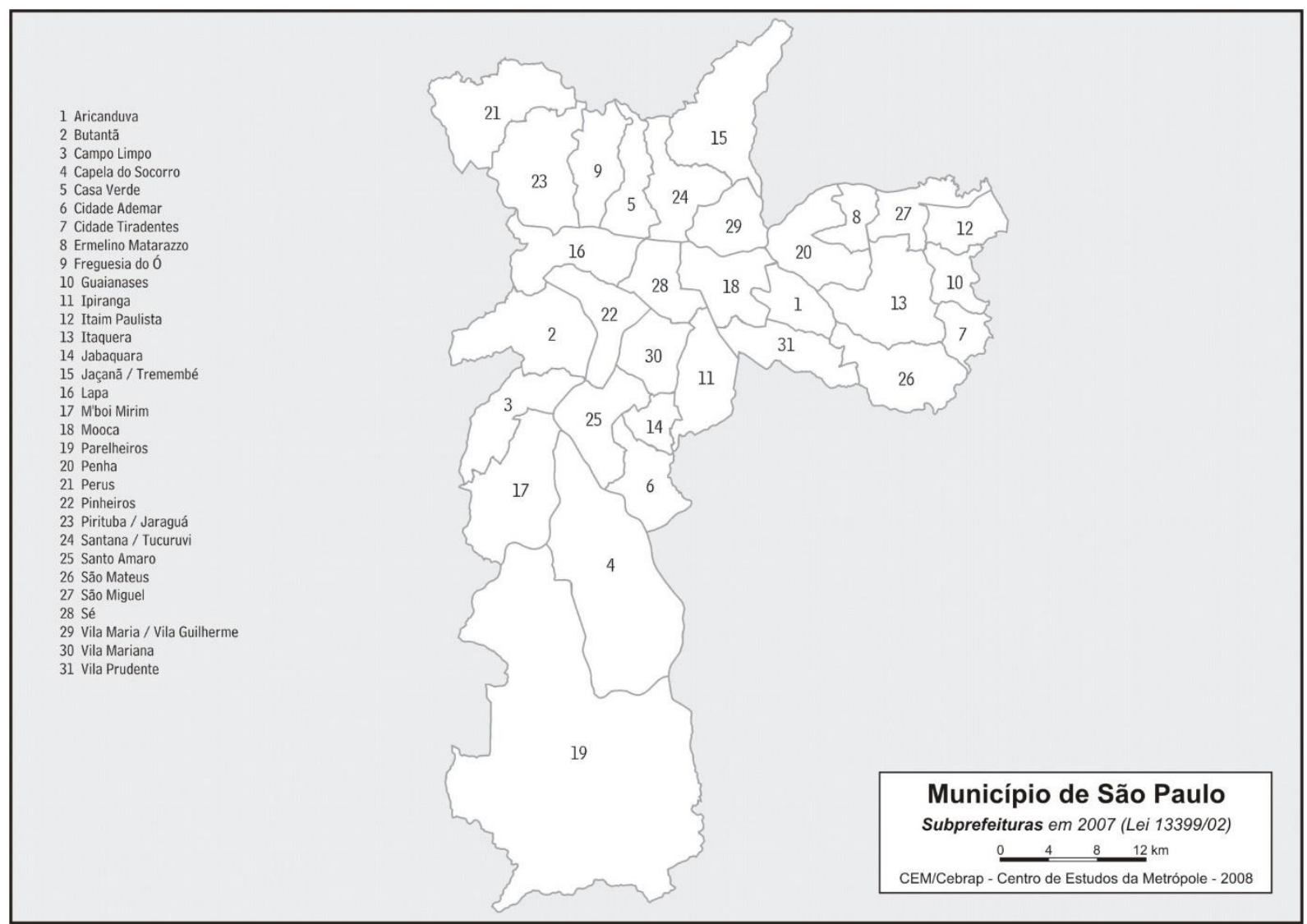

Extraído de: Centro de Estudos da Metrópole (2007). 
Fontes: São Paulo (Município), Lei no 13.399, 2002; Lei nº 15.764, 2013; Decreto nº 54.156, 2013.

Originalmente foram criadas um total de 31 subprefeituras, sendo a $32^{\circ}$ criada em 2013. Em 2017, o então prefeito João Dória alterou a nomenclatura das unidades que passaram a ser denominadas prefeituras regionais. Utilizou-se como critério para os recortes, além da agregação dos distritos, a manutenção de certa homogeneidade dos valores mínimos e máximos de população - critério que já havia sido levado em conta na elaboração dos distritos. Os nomes dos recortes referem-se aos distritos com maior população que compõe cada unidade.

Oficialmente a atribuição das prefeituras regionais é executar as ações de zeladoria no âmbito de seu território - como a limpeza de vias, a poda de árvores, a manutenção de espaços públicos - bem como fiscalizar o cumprimento das leis municipais e auxiliar e ser consultada sobre o planejamento das áreas sob sua jurisdição, por meio de indicação de obras prioritárias, por exemplo. As prefeituras regionais não possuem captação de recursos próprios e não há um percentual do orçamento municipal automaticamente vinculado a elas. Os recursos são repassados pelo tesouro municipal, de acordo as diretrizes do governo em exercício, em observância ao cumprimento do plano diretor e demais planos municipais, bem como das leis orçamentárias. Em tese, há que se observar para a destinação de orçamento às prefeituras regionais o seu quadro de servidores, a natureza da manutenção necessária aos equipamentos públicos dos quais dispõe e a eventual realização de obras e serviços extraordinários.

As prefeituras regionais possuem um prefeito regional escolhido diretamente pelo prefeito municipal. Do mesmo modo, o prefeito pode nomear membros da equipe que trabalhará com o prefeito regional, por meio de cargos comissionados. As prefeituras regionais são organizadas administrativamente mediante coordenadorias setoriais, destinadas aos temas de atendimento ao público, finanças, gabinete e saúde. Do ponto de vista institucional, o modelo de gestão territorial implantado em 2002 e representado pelas prefeituras regionais adquiriram uma estabilidade institucional enquanto órgãos administrativos municipais, sobretudo quando comparada com às antigas administrações regionais. O poder executivo não pode por conta própria criar ou suprimir prefeituras regionais ou as coordenadorias que a compõem, para isso seria necessária a validação das Câmara Municipal mediante a concordância da maioria dos vereadores. À título de comparação, no Município do Rio de Janeiro, por exemplo, as subprefeituras não detém um grau de institucionalização tão profundo, e suas unidades e recortes territoriais podem ser livremente redesenhados de acordo com as preferências do 
governo em exercício (LAMEIRÃO, 2007).

Mesmo considerando a consolidação das prefeituras regionais como estruturas permanentes de apoio à administração municipal, muitos problemas que motivaram a reforma da gestão territorial descentralizada de São Paulo - integração de cadastros territoriais, melhoria de gestão pública, planejamento intersetorial e aumento da participação popular - permanecem e algumas das atribuições legais das prefeituras regionais não são colocadas em prática, de modo que cada governo altera a importância política e a autonomia dos núcleos de administração regional paulistana. De todo modo, nota-se que a consolidação do modelo de descentralização política-administrativa representada pelas prefeituras regionais foi fundamental para o aprofundamento da agenda de implementação de canais participativos da gestão pública paulistana, sobretudo os conselhos participativos municipais. 


\subsection{As instâncias participativas paulistanas e os conselhos participativos municipais}

Em consonância com o contexto internacional de reestruturação do capitalismo e, consequentemente, das estruturas políticas estatais, a partir dos anos 1980 houve um aprofundamento das discussões sobre incorporação da participação cidadã nos órgãos institucionais em diferentes níveis. No Brasil, essa demanda foi parcialmente cristalizada na Constituição de 1988, a qual prevê em alguns de seus artigos mecanismos compulsórios de consultas populares, formação de conselhos e instrumentos de transparência. No âmbito das políticas urbanas, previa-se a participação popular na definição dos planos diretores das cidades, e esse processo foi regulamentado e consolidado com a promulgação do Estatuto das Cidades, em 2000. No entanto, nesse ínterim algumas experiências de participação popular na gestão urbana foram implementadas, como o Orçamento Participativo em Porto Alegre a partir da década de 1990. Na capital paulista, a temática participativa foi incorporada à Lei Orgânica Municipal, já em 1990.

Inicialmente, estava previsto que a instância de participação popular paulistana mais importante seriam os conselhos de representantes. Tratava-se de um grupo que seria eleito diretamente pela população local e teria participação nas decisões sobre o planejamento e a gestão urbana municipal nos territórios sob jurisdição das subprefeituras. No entanto, alguns grupos políticos temiam que a descentralização esvaziasse o poder executivo central, e alegaram que instrumentos que estimulavam a participação direta da população no planejamento, como os conselhos de representantes, eram inconstitucionais. Sob influência desse posicionamento, no decorrer da gestão José Serra (2005), o Ministério Público Estadual denunciou o Poder Público Municipal, e o mesmo foi impedido de estabelecer o conselho de representantes - complemento fundamental das subprefeituras - por decisão judicial. Até hoje aguarda-se o desfecho desse processo no Supremo Tribunal Federal (STF).

De qualquer modo, a partir da década de 2000 ocorreu a implementação do processo participativo de modo mais institucionalizado no município, seja para o planejamento centralizado ou regionalizado com base nas subprefeituras, sobretudo desde 2013, na gestão do prefeito Fernando Haddad (PT - 2013-2016). Já na campanha eleitoral de 2012 ele se comprometeu com a ampliação da descentralização política-administrativa das subprefeituras. Um dos sinais afirmativos em torno disso ocorreu por meio da aprovação de uma subprefeitura a mais, a de Sapopemba, ainda em 2013. No mesmo ano, aprovou-se a criação dos conselhos 
participativos municipais - substitutos provisórios dos conselhos de representantes enquanto sua legitimidade não era julgada no STF. Entretanto, cabe destacar que o conselho participativo municipal possui autonomia significativamente reduzida quando comparado ao que era previsto para os conselhos de representantes na Lei Orgânica - quando se leva em conta a dimensão estritamente legal.

Considerando o processo de institucionalização de participação popular na gestão municipal nesse período, cabe verificar o contexto normativo do conjunto de instâncias criadas para situar o conselho participativo municipal. Na gestão Haddad houve um esforço de sistematização dos instrumentos de planejamento previamente existentes articulando-os com alguns novos criados nesse governo, sejam aqueles do poder executivo centralizado, sejam das prefeituras regionais ou dos canais participativos populares. Esse conjunto de instâncias foi denominado Sistema Municipal de Planejamento Urbano, e prevê a articulação entre o Plano Diretor Estratégico (PDE), a Lei de Uso, Ocupação e Parcelamento do Solo Urbano (LPUOS), leis orçamentárias e os planos regionais e de bairros, tal como a Figura 1 a seguir.

Figura 1 - Sistema Municipal de Planejamento Urbano do Município de São Paulo 2016

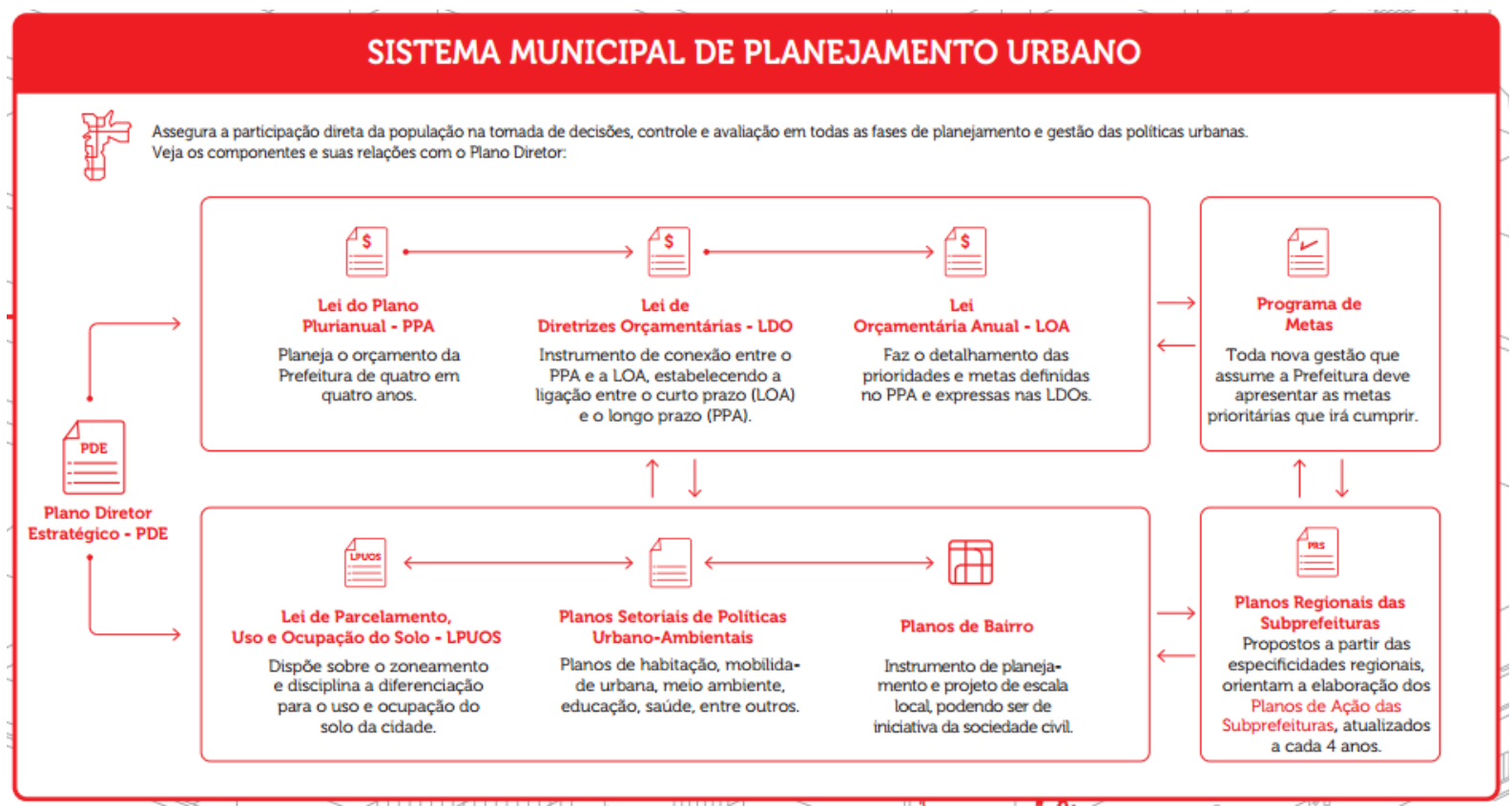

Extraído de: Gestão Urbana SP. Disponível em: <http://gestaourbana.prefeitura.sp.gov.br/um-plano-parafortalecer-a-participacao-popular-nas-decisoes-dos-rumos-da-cidade-2/>. Acesso em: 25 jan. 2016. 


\subsubsection{Instâncias participativas no Sistema Municipal de Planejamento Urbano}

Sob a perspectiva de governo mais ampla, há o Conselho Gestor da Cidade de São Paulo, reorganizado em 2017 a partir do Conselho da Cidade de São Paulo criado em 2013. Trata-se de um conselho de notáveis da sociedade civil selecionado pelo poder executivo para aconselhar as políticas públicas gerais do governo, por esse motivo há especialistas em diversos temas, tanto do ponto de vista técnico como político. O modelo lembra o Conselho de Desenvolvimento Econômico e Social (CDES), conhecido como "Conselhão", implantado desde 2003 no governo federal. Houve críticas a esse fórum municipal por parte de alguns integrantes, devido ao fato de o governo nem sempre consultá-lo em tempo hábil sobre todos os temas relevantes, além de ter sido registrado certo esvaziamento das reuniões. Todavia esse fórum consultivo ainda opera e está presente na estrutura normativa municipal.

No SMPU, o Plano Plurianual (PPA) e as leis orçamentárias são instrumentos de planejamento presentes em todas as esferas do poder executivo brasileiro (união, estados e municípios) e estabelecem os parâmetros gerais dos gastos públicos para períodos de 4 anos, no caso dos planos plurianuais, e de 1 ano, no caso da Lei de Diretrizes Orçamentárias (LDO) e da Lei Orçamentária Anual (LOA). O plano plurianual é um instrumento eminentemente de governo, portanto não prevê participação popular, caso semelhante ao do Programa de Metas este foi um meio encontrado no Município de São Paulo para dar maior visibilidade às realizações do poder executivo, pois julgou-se que assim tornar-se-ia mais fácil a fiscalização ao se comparar com o acompanhamento do PPA. As leis orçamentárias são efetuadas com iniciativa do executivo e necessitam ser aprovadas no legislativo. A participação da população de modo institucionalizado no processo de elaboração das leis orçamentárias ou das emendas a elas ocorre por meio de audiências públicas ou através da formação de conselhos de orçamento participativo. No Município de São Paulo, criou-se um Conselho de Planejamento e Orçamento Participativos (CPOP) em 2013, o qual contava com representantes eleitos, dos quais alguns necessariamente deveriam ser oriundos dos conselhos participativos municipais das prefeituras regionais. O CPOP operou na capital paulista até julho de 2017, quando foi extinto por decreto na gestão João Dória. A partir de então, o único modo institucionalizado para a população participar do processo de elaboração orçamentária se dá mediante as audiências públicas. 
O planejamento setorial do município também incorporou mecanismos de participação cidadã para a elaboração e realização de políticas públicas. Criaram-se diversos conselhos temáticos com representações civis e populares, sendo o mais relevante deles o Conselho Municipal de Política Urbana (CMPU), com o objetivo de institucionalizar a participação popular na formulação de políticas públicas para o desenvolvimento urbano. Trata-se de um conselho consultivo, em que parte dos integrantes são componentes do governo e parte são eleitos entre os munícipes, com reserva de participação a munícipes oriundos de cada um dos 32 territórios regionais. O Conselho do Meio Ambiente e Desenvolvimento Sustentável (CADES) é outro desses conselhos estabelecidos há mais tempo, possui composição muito similar ao CMPU e propõe diretrizes para a preservação do meio ambiente em âmbito municipal. O CADES possui unidades regionais denominadas Conselhos Regionais de Meio Ambiente, Desenvolvimento Sustentável e Cultura de Paz, as quais ficam sediadas nas prefeituras regionais. Os membros dos CADES Regionais em parte são escolhidos por votação no âmbito dos territórios das regionais do município.

Ainda no âmbito setorial, há conselhos estabelecidos mais recentemente, em áreas como transporte, habitação e direitos de minorias. Há também grupos de aconselhamento e gestão de espaços públicos específicos como praças, parques e espaços culturais. Algumas instâncias participativas que operam em territórios específicos do município não necessariamente compõem o arranjo normativo municipal. É e o caso dos tradicionais Conselhos de Segurança Comunitárias (CONSEGs), estabelecidos de acordo com as áreas de jurisdição da Polícia Militar (PM), nos quais os cidadãos fazem demandas e fiscalizam o trabalho dos agentes de segurança pública nas suas regiões. Frequentemente as reuniões dos CONSEGs ocorrem em auditórios das sedes das prefeituras regionais. Outro órgão relevante nesse sentido são os Conselhos Tutelares, presentes em todos os municípios do país, e compostos por membros eleitos pela comunidade.

Entre os componentes do Sistema Municipal de Planejamento Urbano, o Plano Diretor Estratégico (PDE) provavelmente é o mais conhecido e o que possui diretrizes mais explícitas de necessidade de inclusão de participação cidadã em sua elaboração. O último PDE paulistano aprovado em 2015 contou com uma ampla estrutura consultiva estabelecida institucionalmente, por meio de audiências públicas temáticas, grupos de trabalho e consultas pela internet. No que tange às subprefeituras, couberam a elas o papel de organizar atividades e consolidar sugestões de incorporação ao PDE. Mecanismos participativos muito similares foram aplicados na 
reformulação do zoneamento (LPUOS), na medida em que essa constitui um tipo de regulamentação do PDE, com o estabelecimento de regras mais detalhadas para o parcelamento e uso do solo urbano.

A maior parte da elaboração do PDE e da LPUOS ocorreu antes da instalação dos conselhos participativos municipais, mas eles foram consultados para estabelecer os planos regionais das subprefeituras. Esses planos, aprovados em 2016, estabelecem prioridades de atuação e detalham o PDE nas regiões da capital paulista. Além da participação dos CPM, a população pôde ser consultada por meio de conferências regionais e pela internet. Houve também a participação de setores da administração pública por meio dos Núcleos Regionais de Planejamento (NRP), composto por um colegiado intersetorial. O Plano de Ação das Subprefeituras, válido pelo período de 4 anos, deve estabelecer quais medidas previstas nos Planos Regionais serão implementadas no período, bem como regular o cumprimento do Programa de Metas do governo nas unidades regionais.

Essa breve descrição do Sistema Municipal de Planejamento urbano paulistano, considerando as instâncias participativas e descentralizadas que o compõe, mostra uma grande complexidade do ponto de vista normativo. São muitos instrumentos de planejamento, órgãos e instâncias participativas operando no planejamento urbano. Isso coloca a questão de como esse sistema atua na prática, ou seja, se essas integrações entre instâncias previstas em lei funcionam de fato, e se os planos setoriais são compatíveis com os planos territoriais integrados. Ademais, percebe-se a necessidade de circunscrição da análise a uma instância específica para tentar delinear empiricamente a participação popular institucionalizada. Os conselhos participativos municipais, dado o seu caráter territorializado, de composição estritamente ligada à população e conectado a outros fóruns municipais pode sintetizar os desafios e possibilidades do processo participativo institucionalizado de gestão urbana.

\subsubsection{Os conselhos participativos municipais}

Os conselhos participativos municipais são instâncias participativas no âmbito das prefeituras regionais, compostos por munícipes eleitos nos territórios paulistanos sob jurisdição das regionais. Os CPM têm como principais funções estabelecer um canal de diálogo entre as prefeituras regionais e os munícipes, organizando as demandas locais, sugerindo ações e políticas públicas para os distritos e bairros, além de fiscalizar a gestão dos prefeitos regionais. 
Trata-se de um conselho com atribuições eminentemente consultivas, ou seja, as resoluções tomadas nas reuniões do CPM não devem ser necessariamente cumpridas pelos governos regionais do município, contudo as demandas e discussões são registradas em Diário Oficial do Município e é dever das prefeituras regionais prestar contas ao conselho. O número de conselheiros é variável em função do número de distritos e de população da regional e há eleições a cada dois anos.

\section{Eleições e representatividade}

Segundo a lei que instituiu os CPM, os conselheiros, assim como seus eleitores, devem ser munícipes residentes na área da regional na qual pretendem ser representantes e serem maiores de 18 anos. A representação deve ser proporcional ao número de distritos e à população que compõem a subprefeitura/prefeitura regional, ficando resguardado o número mínimo de 5 conselheiros por distrito.

O primeiro processo eleitoral dos CPM ocorreu em 2013, para eleger conselheiros para o biênio 2014-2015. Candidataram-se 2.800 pessoas e foram eleitos 1.125 conselheiros, com mais de 400 mil votos. Para ser candidato, havia necessidade de apoio, expresso por lista de assinatura, de pelo menos 100 munícipes residentes no distrito em questão. As zonas eleitorais, estabelecidas pelo Tribunal Superior Eleitoral (TSE) possuem limites diversos daqueles das prefeituras regionais, de modo que na eleição de 2013 foi facultado ao munícipe votar para compor o conselho de mais de uma subprefeitura, caso ele residisse numa zona eleitoral que contivesse mais de uma subprefeitura. Nessa eleição, cada eleitor tinha direito de votar em até 5 candidatos.

No pleito de 2015, que elegeu os CPM para mandato no biênio 2016-2017, houve modificações no processo eleitoral. Os candidatos não necessitavam mais de apoio mínimo de 100 munícipes para serem elegíveis. Outras modificações importantes foram a incorporação da proporcionalidade de 50\% de mulheres para o CPM, seguindo legislação municipal, e também cadeiras reservadas para imigrantes, em número proporcional aos estrangeiros em cada distrito. Candidataram-se 2.485 pessoas, foram eleitos 1.160 conselheiros e com mais de 130 mil votos participaram do processo.

O processo eleitoral de 2017 introduziu mais mudanças em relação aos anos anteriores. Os eleitores passaram a ter apenas um voto por candidato em cada prefeitura regional. Mas a 
alteração mais significativa foi a redução no número de conselheiros por distrito e prefeitura regional. A representatividade que antes era de um conselheiro para cada 10.000 habitantes de prefeituras regionais, caiu de um para cada 30.000 habitantes (SÃO PAULO [Município], Decreto $\left.n^{\circ} 57.829,2017\right)$. No total, houve uma queda de 50,9\% do total de vagas para os CPM. A nova legislação privilegia a representação por território mas subestima a proporcionalidade da população por distrito/regional. Campo Limpo, por exemplo, é a prefeitura regional com maior número de habitantes (607.105), e tem 21 cadeiras de conselheiros, enquanto a Sé contará com 40 conselheiros, apesar de possuir menor número de habitantes (431.106). Isso ocorre pelo maior número de distritos que a regional da Sé possui (8) em relação a de Campo Limpo (3). A gestão Doria foi criticada pela medida, principalmente pelo argumento de que não há qualquer impacto orçamentário que a justifique, na medida em que o único gasto significativo com os CPM refere-se ao processo eleitoral. No entanto, o então secretário municipal de Relações Governamentais, Milton Flávio, argumentou que a medida foi tomada em razão da baixa frequência de conselheiros em algumas reuniões e ainda alegou que a medida não impactaria a participação social por se tratar de um fórum consultivo (G1 SP, 2017).

\section{Estrutura formal e reuniões ordinárias}

Os CPM são regulados por regimentos internos, aprovados pelos próprios conselheiros. São nos regimentos que se definem as normas específicas do funcionamento dos conselhos, como a dinâmica das reuniões e as regras de escolha coordenadores, secretarias e outros cargos internos. Em geral, os CPM possuem um coordenador e um secretário - eleitos entre os próprios conselheiros semestralmente - responsáveis pelas convocações das reuniões ordinárias e extraordinárias e pela elaboração das atas dos encontros.

As reuniões ordinárias são os fóruns básicos dos conselhos e ocorrem mensalmente, na maioria das vezes estabelecendo-se um dia específico da semana para ela ocorrer, com duração de 2 a 3 horas. O CPM de Pinheiros em 2016, por exemplo, estabeleceu a primeira terça-feira de cada mês como dia oficial das reuniões, com horário às 19 horas. A pauta e o local do encontro devem ser decididos com antecedência para que possam ser divulgados no Diário Oficial do Município e também no site da prefeitura, afim de manter a publicidade do evento. Apesar dessa diretriz, no decorrer da presente pesquisa foi relativamente comum as convocatórias e calendários de reuniões estarem indisponíveis no site da prefeitura e, em alguns 
casos, no Diário Oficial. As atas também devem ser publicadas em Diário Oficial, após a aprovação dos integrantes dos conselhos - o encaminhamento à publicação em Diário Oficial ocorre por intermédio da prefeitura regional, e em alguns casos a publicação das atas pode levar meses até acontecer, seja por atraso na redação, na aprovação em reunião ordinária ou no encaminhamento da prefeitura regional à imprensa oficial do município. Em geral, estabelecese um quórum de conselheiros presentes para a realização da reunião, número que varia de acordo com o regimento de cada CPM.

Os CPM geralmente contam com um pequeno patrimônio e orçamento, destinado a organização e custeio das suas atividades. Há conselhos que contam com salas próprias na sede das prefeituras regionais, possuindo objetos como computador, impressora, data-show e materiais de papelaria. As prefeituras regionais têm obrigação de conseguir o espaço para a realização das reuniões. Na maioria das vezes elas ocorrem em auditórios situados nas sedes das regionais. No entanto, há conselhos que alternam a localização das reuniões ou que as modificam eventualmente em razão de eventos específicos. O CPM da Freguesia do Ó/Brasilândia por exemplo, realiza reuniões tanto na sede da prefeitura regional, na Freguesia do Ó, quanto no Clube da Comunidade (CDC) Oswaldo Brandão, situado na Vila Brasilândia, ou ainda na Casa de Cultura, também na Vila Brasilândia.

As reuniões dos CPM são abertas a toda população, mas em geral a maioria esmagadora dos presentes são os próprios conselheiros. Mesmo assim, sempre há um número significativo de faltas dos conselheiros, muitas vezes menos da metade dos conselheiros estão presentes. Os munícipes não-conselheiros que participam eventualmente das reuniões o fazem para reivindicar alguma causa específica, como relatar um problema em uma infraestrutura de bairro ou fazer uma reivindicação em nome de um movimento de moradia, por exemplo. Quase sempre há a presença de um interlocutor da prefeitura regional nas reuniões dos CPM, desse modo as resoluções e discussões podem ser levadas ao gabinete da regional. As experiências de campo e os relatos de conselheiros mostram que raramente os prefeitos e prefeitas regionais participam das reuniões, e em alguns casos mesmo os interlocutores se ausentam. Muito raramente comparecem aos CPM outros tipos de representantes políticos estatais, como vereadores, assessores de deputados ou secretários municipais. É importante destacar a existência de mecanismos de controle de ausentes entre os conselheiros, como listas de presença, e a necessidade, em alguns CPM, de justificar as ausências, de modo que a não 
justificativa pode implicar substituição do conselheiro por seu suplente - após um número específico de faltas não justificadas.

Figura 2 - Reunião do CPM de Cidade Ademar em 30/09/2017

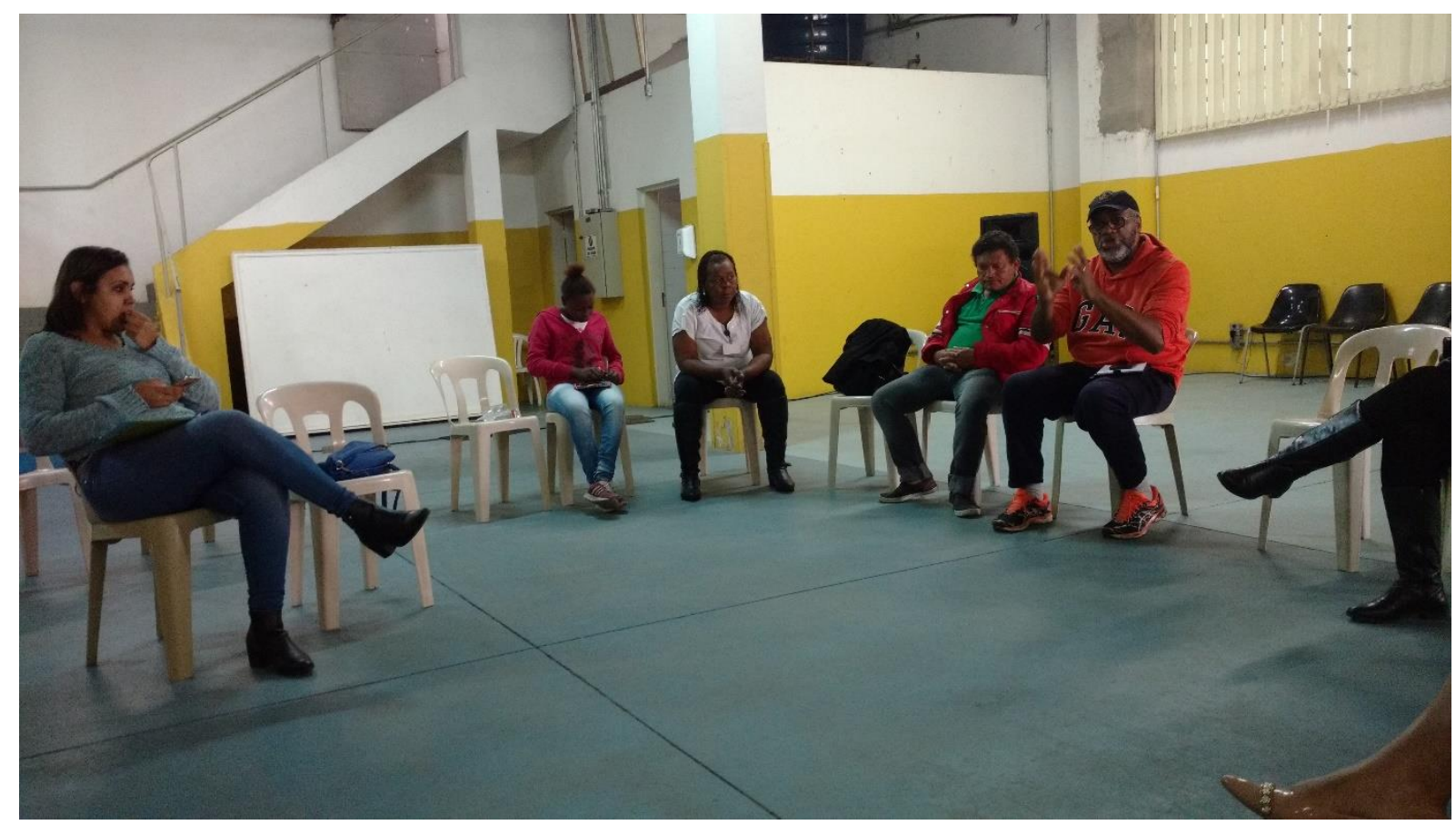

Fonte: Acervo do autor.

As reuniões se iniciam na maioria das vezes com a aprovação da ata da última reunião, ora lida em voz alta, ora mediante a leitura prévia por e-mail. O coordenador verifica se há quórum para reunião e inicia-se pela leitura das pautas e o levantamento de informes por parte dos conselheiros. Em seguida ocorrem as discussões propriamente ditas, se houver muitos interessados em falar, eventualmente realiza-se o sistema de inscrições e tentativas de controle do tempo de fala. Ao fim da reunião, sistematiza-se os eventuais encaminhamentos e procedese a decisão sobre a pauta da reunião seguinte, bem como a confirmação de data e horário. Quando há votações, apenas os conselheiros têm direito a votos, os munícipes não-conselheiros ou representantes governamentais não são contabilizados para esse propósito.

Entre as discussões mais observadas durante as visitas às reuniões ordinárias de CPM destacam-se o diagnóstico sobre o próprio CPM, como sugestões para melhoria das dinâmicas dos encontros, reclamações sobre ausências - tanto de conselheiros como de representantes das regionais - ou queixas sobre o tratamento pouco atencioso dos gabinetes dos prefeitos regionais 
ao CPM. Outro tema muito recorrente são as denúncias de irregularidades nos bairros e distritos ou o atraso de cumprimento de compromissos da prefeitura regional nas localidades, numa reunião no CPM de Cidade Ademar, por exemplo, os conselheiros cobraram a prefeitura regional em relação a instalação de um ecoponto em um dos distritos da regional, promessa que estava pendente há pelo menos 9 meses antes dessa reunião. Outra questão muito frequente nas reuniões são as demandas trazidas para serviços e obras em bairros, embora seja frequente lembrarem nas reuniões que determinadas reclamações nesse sentido deveriam ser enviadas às praças de atendimento das prefeituras regionais, e não aos CPM. A depender da necessidade, os conselheiros organizam comissões e grupos de trabalhos sobre temas específicos, e realizam contatos ou reuniões fora do momento das reuniões ordinárias, e a partir disso fazem estudos e sugestões para solucionar algum problema específico. Os CPM foram ainda consultados para a consolidação dos Planos Regionais das Subprefeituras, embora alguns conselheiros de CPM específicos tenham relatado que não houve uma discussão tão intensa sobre o tema, apesar da importância do mesmo.

A gestão municipal de São Paulo passou por um paulatino processo de descentralização neste século, especialmente a partir da década de 2000. Da mesma forma, e frequentemente associada às medidas de descentralização, foram criadas numerosas instâncias de participação popular institucionalizadas, das quais as mais relevantes são os conselhos setoriais e os conselhos participativos nas regionais. Com base nessas constatações, percebe-se que os canais participativos em âmbito institucional existem e possuem algum grau de operação, garantidos na dimensão normativa. Contudo, nota-se uma frequente insatisfação com esses fóruns decisórios, ora expressada pelo poder constituído - exemplificada por medidas como a extinção do Conselho do Planejamento e Orçamento Participativo por parte do executivo municipal -, ora expressada pelos munícipes - exemplificada pela significativa redução de candidaturas aos CPM nos últimos pleitos. Alguns dos problemas destacados, ora pela sociedade ora pelos representantes estatais, é o reduzido poder decisório dessas instâncias - em geral relegadas à dimensão consultiva -; o alto percentual de ausências de conselheiros e cidadãos nessas instâncias; e o pouco conhecimento da existência dos canais participativos e das dinâmicas de participação. 
Nos capítulos seguintes, buscar-se-á levar a análise além da dimensão normativa e passar à prática, verificando as condições objetivas de participação da população e as repercussões da participação na produção da geografia da cidade de São Paulo. 


\section{CONDIÇÕES GEOGRÁFICAS DA PARTICIPAÇÃO POPULAR NAS PREFEITURAS REGIONAIS}

A questão da incorporação da participação popular nos processos decisórios da cidade raramente leva em consideração um fator fundamental: as condições que os habitantes efetivamente possuem de dispor do seu tempo e trabalho em favor da integração nesses fóruns. Muitas pessoas têm pouca margem em suas rotinas para esse tipo de atividade, pois além do trabalho, do estudo (ou de ambos), dos longos deslocamentos realizados no decorrer do dia, há ainda a necessidade de dar conta das tarefas domésticas, bem como falta de dinheiro para pagar mais um transporte até o local em que ocorrerá a reunião (como a sede de uma prefeitura regional, por exemplo). Há ainda os casos de pessoas que se sentem afastadas da participação em instâncias formais de atuação política por conta de pouca formação educacional, de modo que julgam não conseguir compreender adequadamente os temas discutidos, os protocolos de reunião, etc.

Esse capítulo pretende discutir essa problemática sob uma perspectiva geográfica, mais especificamente analisando características geográficas da cidade de São Paulo que podem dificultar o processo participativo nos CPM das prefeituras regionais. Por um lado, os referenciais espaciais da cidade são muito relevantes nesse processo, pois eles são decisivos para saber se o morador de determinada localidade identifica uma demanda como "sua", do "seu bairro" - por exemplo -, além de dar indícios sobre a possibilidade dos cidadãos perceberem as prefeituras regionais como locus de resolução e encaminhamento de demandas específicas. Por outro lado, a distribuição desigual na cidade de condições materiais, socioeconômicas e culturais pode demonstrar facilidades ou dificuldades extras para moradores de determinados fragmentos urbanos paulistanos se integrarem no processo participativo do modo como é proposto nos CPM.

É importante destacar que a proposta dessa análise não tem como premissa a ideia de que a participação popular só seria possível numa cidade sem nenhuma desigualdade socioeconômica. Apenas pretende-se uma avaliação crítica das possibilidades dessa participação em modelos institucionais formais como os propostos nas prefeituras regionais. 


\subsection{Referências espaciais da cidade e a participação política}

Ao se tratar de participação política em instâncias institucionais de caráter local, é inescapável a premissa de que as pessoas que irão atuar politicamente se declaram parte de uma comunidade, comunidade esta que será mais ou menos bem delimitada geograficamente. Sem a referência básica topológica de uma determinada comunidade, sintetizada pelas pergunta “onde estamos?” ou “onde moramos?”, torna-se muito difícil conceber uma articulação mínima para integrar ações participativas em âmbito institucional. Nesse sentido, o relativo conhecimento pelas diversas comunidades munícipes das referências geográficas institucionais é fator relevante para impulsionar positivamente ou desestimular a participação política. Afinal, parte da identificação de um morador com um problema específico se dará caso esse problema ocorra na "sua" comunidade.

Frequentemente a participação ocorre para solucionar demandas específicas, como criação de escolas, manutenção de parques, asfaltamento de arruamentos, etc. Para se resolver tais demandas, além de saber em qual lugar se vive - do ponto de vista institucional - é ainda necessário saber em qual setor do poder público o habitante deve reclamar: na prefeitura regional ou na secretaria setorial responsável? Esses outros órgãos também possuem instâncias participativas ou centrais de atendimento? E quando há empresas concessionárias envolvidas nos problemas, a quem recorrer? Há ainda subjacente a essa problemática uma questão escalar, pois os moradores da cidade podem se identificar como moradores do seu bairro, distrito, prefeitura regional ou na macrorregião. Esses apontamentos mostram a relevância de se estabelecerem divisões territoriais oficiais que sejam de apreensão relativamente fácil por parte da população, caso haja o desejo de que as pessoas atuem diretamente em instâncias governamentais ou de planejamento e gestão urbana.

As divisões territoriais elaboradas pelo Estado nem sempre são uniformes ou harmônicas entre si. Há inúmeros exemplos de Estados que adotam múltiplas divisões territoriais simultaneamente, muitas vezes para suprir necessidades específicas tais quais o exercício da justiça, a definição de autonomias locais ou atividades administrativas setorializadas. Soma-se a isso o fato de que nem sempre tais divisões são criadas numa mesma lógica, ou seja, é relativamente comum a existência de sobreposições de compartimentações sem qualquer compatibilidade de forma, escala ou função. Esses são alguns dos motivos pelos quais parte significativa das populações desconhecem os critérios e a lógica das divisões 
territoriais. Em circunstâncias extremas, os próprios agentes estatais passam a desconhecer os quadros territoriais do local que gerenciam. Tal situação pode ser verificada no Município de São Paulo.

Há numerosas divisões territoriais no Município de São Paulo. Os registros dos primeiros parcelamentos do território da atual capital paulista remontam ao século XVIII, quando foram criadas as freguesias de São Miguel ${ }^{30}$, Penha de França e Nossa Senhora do Ó. As compartimentações não pararam de ocorrer ao longo de dois séculos e atualmente São Paulo conta com centenas de subdivisões, entre as mais conhecidas estão os 96 distritos e as 32 prefeituras regionais ${ }^{31}$. As constantes subdivisões tornaram o quadro territorial paulistano amplo e, em grande parte, desconexo. Segundo Sposati (2001), há enorme variação nos critérios de agregação dos "pedaços" da cidade para a organização e gerenciamento dos serviços públicos de São Paulo. Para a autora, essa multiplicidade no trato do território faz com que os cadastros territoriais não se comuniquem, dificultando a gestão pública. Mais do que isso, ela sustenta a ideia de que a falta de referências territoriais definidas prejudica o exercício da cidadania: “cada órgão é uma cultura, uma nomenclatura e um conjunto de procedimentos indecifráveis que não compartilham um código comum. Não existe a cidadania do lugar nos registros municipais e muito menos seu acesso democrático aos cidadãos" (SPOSATI, 2001, p.50).

A profusão de divisões territoriais da capital paulista pode ser exemplificada por meio da observação de algumas das divisões do município em zonas cardeais. As zonas cardeais constituem um tipo de parcelamento do território do município que o divide em macrozonas, às quais são atribuídas os nomes das direções cardeais (CAZZOLATO, 2005). Essas talvez constituam a referência mais comum de localização em São Paulo, pois muitas pessoas que circulam pela cidade frequentemente situam os lugares enquadrando-os como pertencentes à zona leste, à zona sul, à zona norte, à zona oeste ou ao centro ${ }^{32}$. Não raras são as discussões e

\footnotetext{
${ }^{30}$ Segundo informações do sistema Cidades@ do IBGE, deduz-se que a freguesia de São Miguel foi desfeita em meados do século XIX. Ela foi recriada em 1871 e suprimida meses depois neste mesmo ano (SÃO PAULO [Estado], Lei no 41, de 30 de março 1871). No início do século XX, São Miguel consta como distrito da capital paulista. Disponível em: <http://cidades.ibge.gov.br/painel/historico.php?lang=\&codmun=355030\&search=saopaulo|sao-paulo|infograficos:-historico>. Acesso em: 25 jan. 2016.

${ }^{31}$ Estabelecidos respectivamente pela Lei Municipal no 11.220 de 20 de maio de 1992 e Lei Municipal no 13.399 de $1^{\circ}$ de agosto de 2002.

${ }^{32}$ A menção das zonas como referências para localização em São Paulo vem de longa data. Na década de 1950, Renato da Silveira Mendes (1958, p.188) utilizou-se das "zonas" para classificar os bairros da cidade, pois elas já eram "[...] admitidas em atos dos poderes públicos e consagradas pelo consenso popular".
} 
polêmicas cotidianas sobre o pertencimento ou não de uma localidade a uma dessas zonas especialmente quando se trata da zona sul ou oeste. Isso não ocorre sem motivos, pois existem muitas divisões diferentes do Município de São Paulo em zonas cardeais. Nesse sentido, algumas das divisões em macrozonas servem a propósitos específicos de setores da administração pública e nem sempre são legalmente reconhecidas - embora possam deter uma institucionalidade tácita. Ao consultar o sítio virtual oficial da Prefeitura do Município de São Paulo (PMSP) encontramos a divisão territorial em zonas cardeais presente no Mapa 3: 


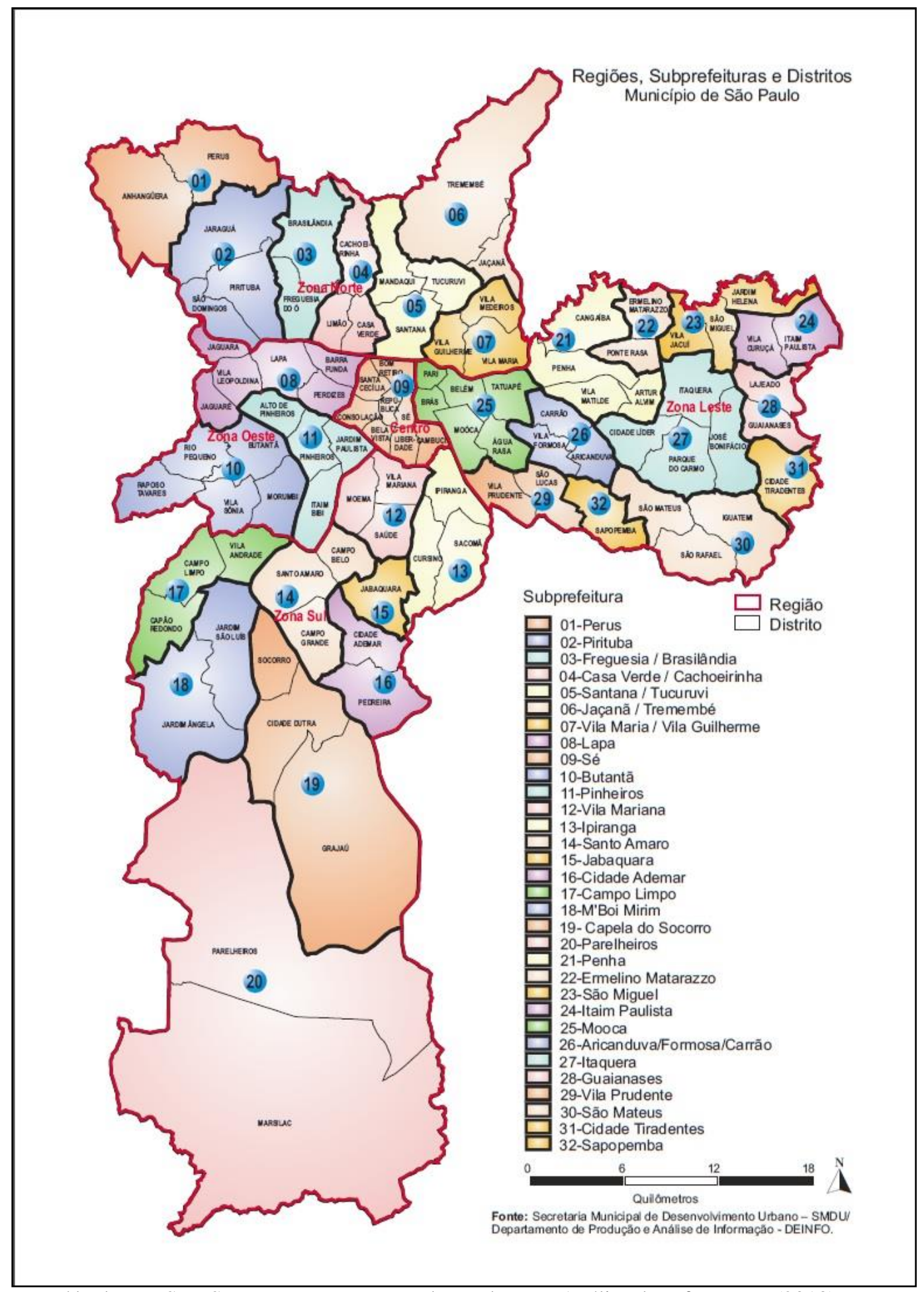

Extraído de: PMSP - SMDU; Departamento de Produção e Análise de Informação (2013).

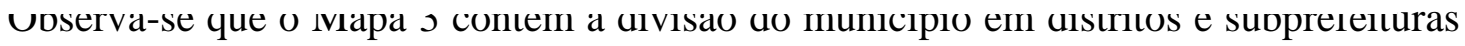
(atuais prefeituras regionais). Essas compartimentações são agregadas em zonas cardeais, 
denominadas Regiões. São cinco no total: Zona Norte, Zona Oeste, Zona Sul, Zona Leste e Centro. Não foi encontrada qualquer legislação que instituiu esta divisão, mas a divulgação por mídia oficial da prefeitura é sinal de que se trata de uma importante referência espacial, dotada de certa institucionalidade para o município.

Entretanto, é possível encontrar outra divisão territorial por zonas do município, como o Mapa 4, também com a chancela da prefeitura: 
Mapa 4 - Divisão do Município de São Paulo em distritos, subprefeituras e zonas cardeais

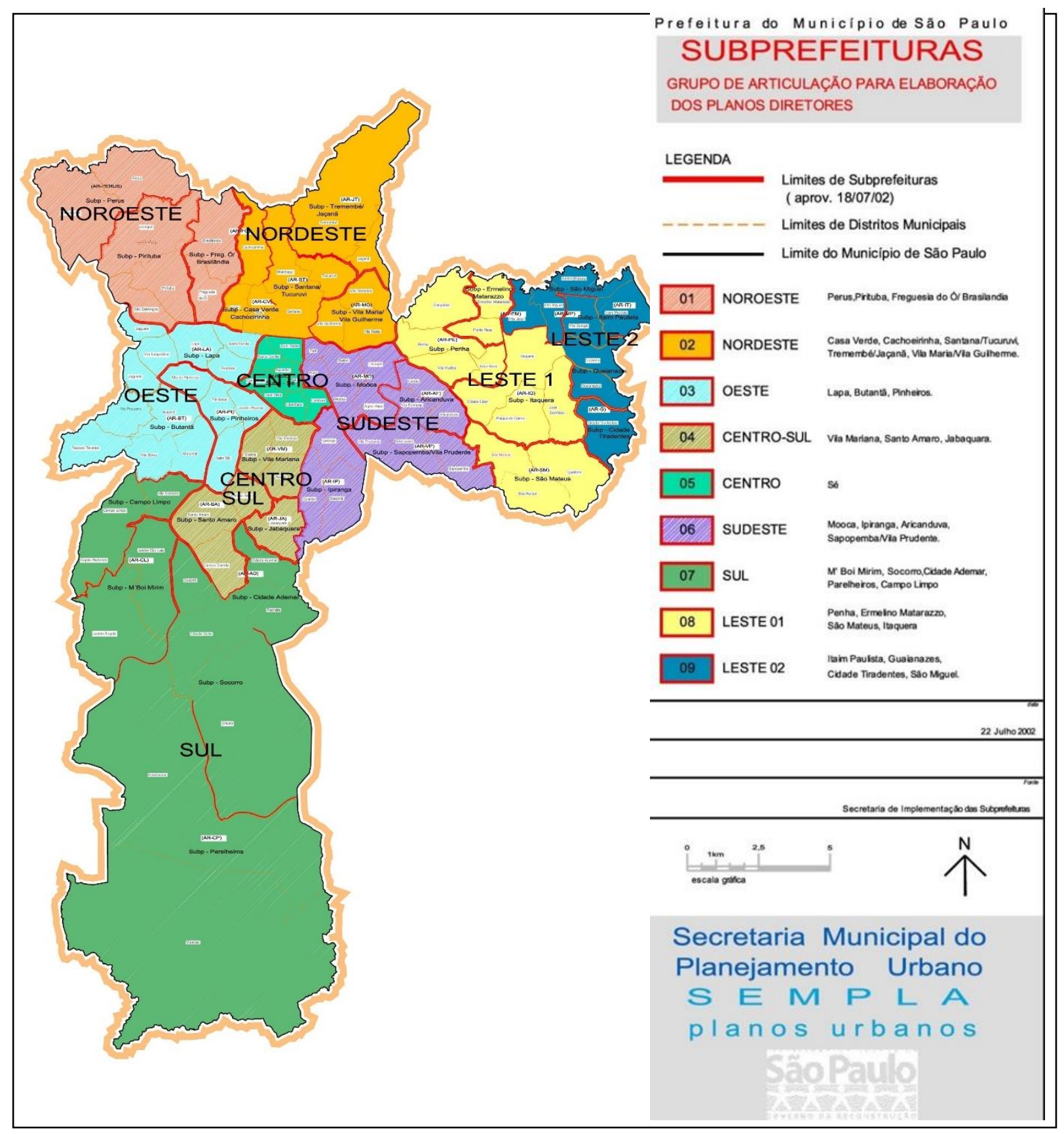

Extraído de: Secretaria de Implementação das Subprefeituras (PMSP - SIS) (2002). 
O Mapa 4 é relativamente recente, foi elaborado em 2002. No Mapa 4 a divisão em zonas cardeais não possui nome e o município foi agregado em nove partes: Noroeste, Nordeste, Oeste, Sul, Centro, Centro-Sul, Sudeste, Leste 1 e Leste 2. Assim como o mapa anterior, este também é resultado da agregação das subprefeituras e dos distritos. O mapa está hospedado em endereço virtual vinculado à prefeitura ${ }^{33}$. A tendência é que essa divisão por zonas cardeais tenha sido substituída em âmbito institucional pela divisão citada no Mapa 4, contudo não há evidências definitivas para essa constatação, na medida em que não foi encontrado nenhum diploma legal que instituiu essa regionalização.

Há divisões de São Paulo em zonas cardeais que são estabelecidas por setores específicos da gestão pública ou por empresas prestadoras de serviços públicos, mas que são amplamente reconhecidas. É o caso da divisão territorial do município utilizada pela Empresa Brasileira de Correios e Telégrafos (ECT/Correios) para a delimitação do Código de Endereçamento Postal (CEP) e da divisão elaborada pela Companhia de Engenharia de Tráfego de São Paulo - SP (CET), representados respectivamente nas Figuras 3 e 4:

\section{Figura 3 - Sub-regiões Postais dos Correios}

\footnotetext{
${ }^{33}$ Conforme as informações do Mapa 4, a fonte é a PMSP - SIS - atual Secretaria Municipal de Coordenação das Subprefeituras (PMSP - SMSP). O mapa pode ser acessado pelo seguinte endereço (vinculado ao domínio virtual da prefeitura): <http://ww2.prefeitura.sp.gov.br//arquivos/guia/mapas/0001/mapa_subprefeituras.jpeg>.
} 


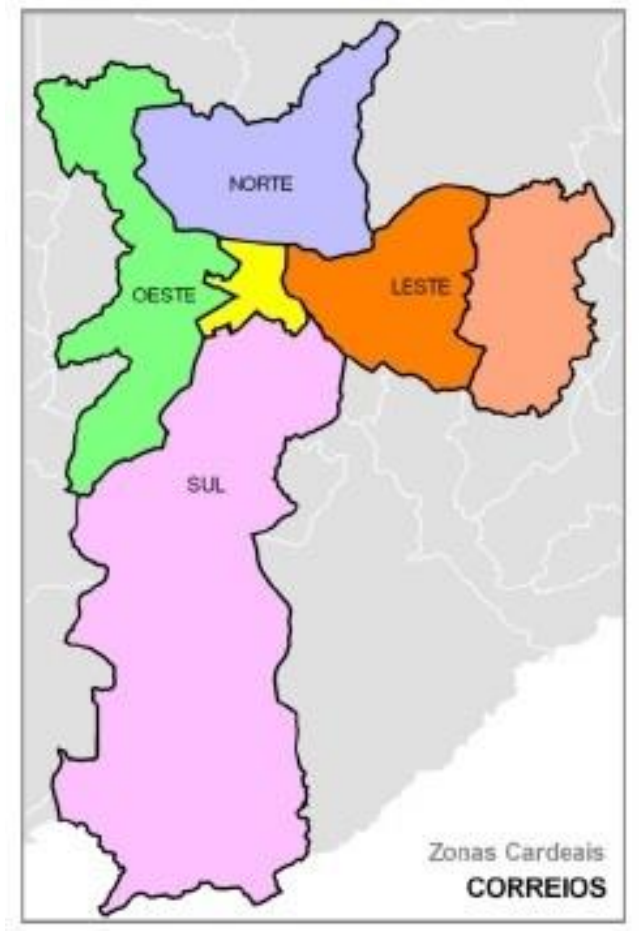

Extraído de: Cazzolato (2005, p.13).

Nota: Baseadas na continuidade dos dois primeiros dígitos do CEP 
Figura 4 - Mapa do Trânsito da CET

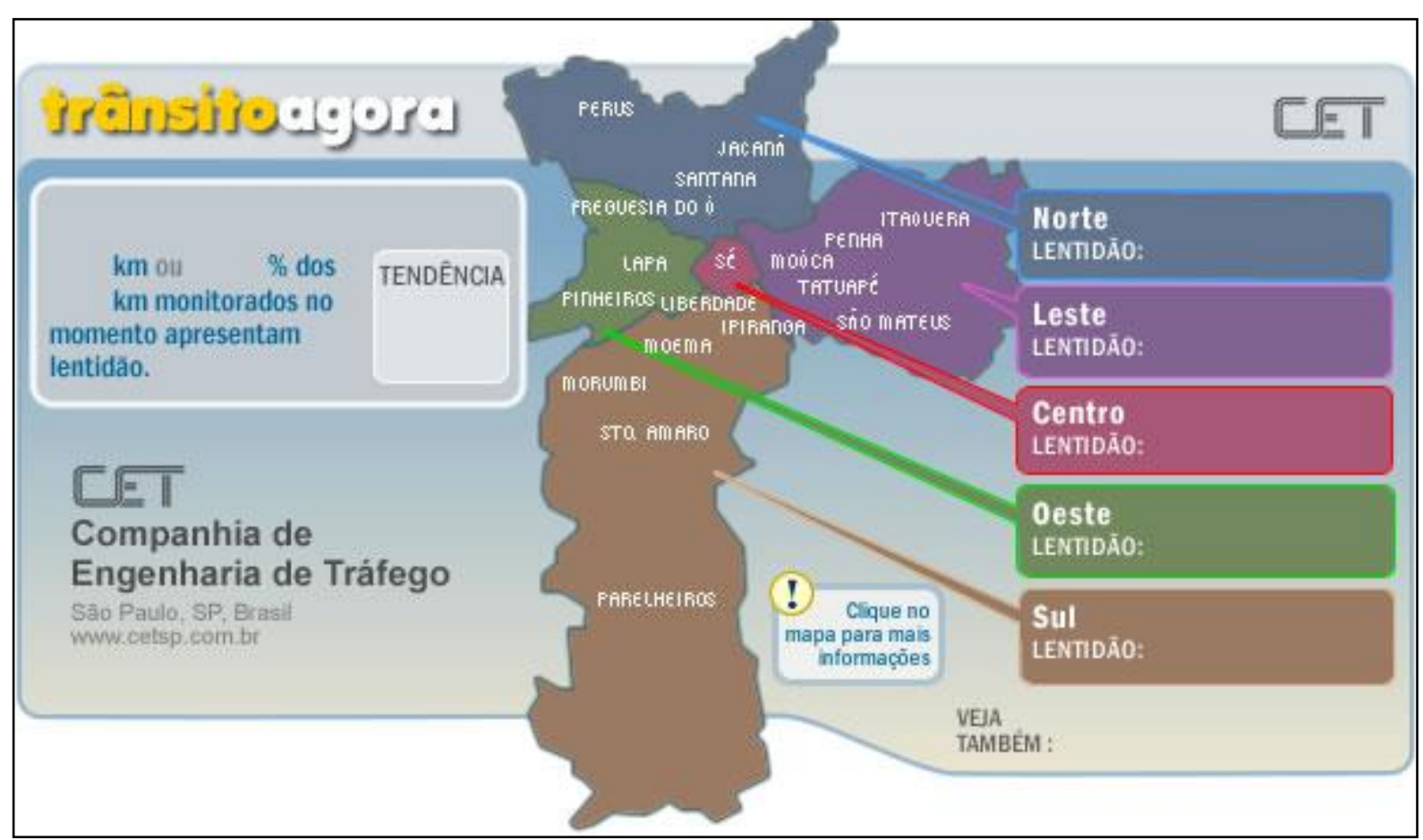

Extraído de: CET. Disponível em: <http://cetsp1.cetsp.com.br/monitransmapa/agora/>. Acesso em: 25 jan. 2016.

A regionalização elaborada pelos Correios para o Município de São Paulo mostrada na Figura 3 representa seis sub-regiões postais ${ }^{34}$, e está no formato de divisão do município em zonas cardeais (CAZZOLATO, 2005). Porém, essa divisão não é equivalente às mostradas anteriormente. Caso semelhante ocorre com a regionalização proposta pela CET, que é consultada diariamente por milhares de pessoas que circulam em veículos pela cidade, bem como pela mídia ao noticiar a situação de tráfego no município. O Mapa do Trânsito (Figura 4) é um sistema de monitoramento e informação de trânsito constantemente atualizado. "A cidade foi dividida em cinco regiões: Centro, Leste, Norte, Oeste e Sul. Para cada uma delas são apresentados o índice e a porcentagem de lentidão comparados ao trânsito da cidade toda e a tendência do comportamento do trânsito" ${ }^{35}$. Percebe-se que não há correspondência exata entre o zoneamento estabelecido pela CET com as outras divisões mostradas.

\footnotetext{
${ }^{34}$ A sexta sub-região postal, representada na Figura 3 pela subdivisão da zona Leste, é parte da área abrangida pelos dígitos 08 no início do CEP. Essa área estende-se aos municípios de Ferraz de Vaconcelos, Poá, Itaquaquecetuba, Suzano, Moji das Cruzes, Guararema, Biritiba Mirim e Salesópolis (CAZZOLATO, 2005).

35 Disponível no link “Ajuda"; "Divisão da cidade em regiões" do site da CET. Disponível em: <http://cetsp1.cetsp.com.br/monitransmapa/agora/ajuda.htm>. Acesso em: 25 out. 2013.
} 
Outra importante divisão do município em zonas cardeais foi a instituída pela São Paulo Transporte S.A. (SPTrans) - empresa responsável pela gestão do sistema de transporte coletivo por ônibus em São Paulo. Em 2002, foi decretada a divisão do município em áreas que delimitam a abrangência espacial das concessões de operação do transporte coletivo por ônibus no município ${ }^{36}$. O consórcio e as cooperativas responsáveis por cada área sinalizam os ônibus com um mesmo padrão de cor, que é diferente para cada uma das áreas delimitadas ${ }^{37}$. A Figura 4 apresenta a divisão em zonas cardeais da SPTrans:

\section{Figura 5 - Divisão do Município de São Paulo em Áreas de Concessão da SPTrans}

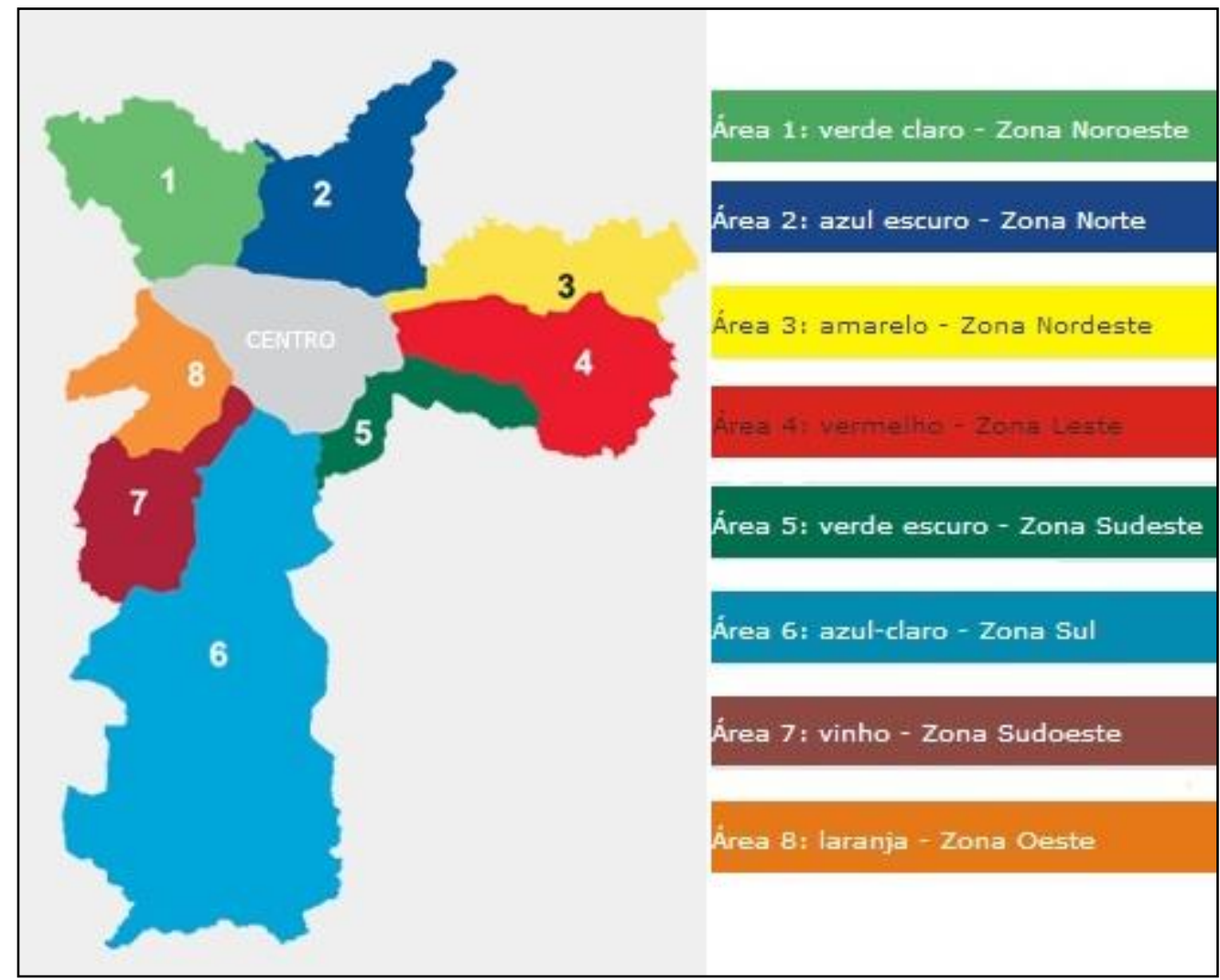

Fonte: Adaptado de SPTrans. Disponível em: 〈http://www.sptrans.com.br/a_sptrans/sistema.aspx>. Acesso em: 25 jan. 2016.

Nota: Cada Área delimita a extensão da concessão dos consórcios do transporte coletivo de ônibus paulistanos

\footnotetext{
${ }^{36}$ Inicialmente a divisão foi estabelecida pelo Decreto $\mathrm{n}^{\mathrm{o}} 42.736$, de 19 de dezembro de 2002. O Decreto $\mathrm{n}^{\mathrm{o}} 53.887$, de 8 de maio de 2013 revoga o Decreto $\mathrm{n}^{\circ}$ 42.736, mas estabelece a mesma divisão do município para delimitar as áreas de concessão (SÃO PAULO [Município], Decreto nº 53.887; 2013).

${ }^{37}$ De acordo com o texto Sistema Municipal de Transporte, que consta no site da SPTrans. Disponível em: <http://www.sptrans.com.br/a_sptrans/sistema.aspx>. Acesso em: 25 jan. 2016.
} 
São nove divisões ao todo: Zona Norte, Zona Noroeste, Zona Oeste, Zona Sudoeste, Zona Sul, Zona Sudeste, Zona Leste, Zona Nordeste e o Centro, equivalente ao Centro Expandido da cidade ${ }^{38}$. O último não possui consórcio, sendo abarcada pelos ônibus das outras áreas (SPTRANS) - portanto, não existe indicação específica de cor para ônibus que circulam pelo Centro.

Além de ser importante referência para a localização e para a organização do transporte coletivo de São Paulo, esta divisão em zonas cardeais está demarcada nos logradouros do município por meio de placas de identificação. Desde de 2007 as placas passaram a ser sinalizadas na margem inferior com a cor da zona à qual pertencem (conforme a Figura 5), de modo a facilitar a referência espacial tanto para quem utiliza o transporte coletivo, quanto para quem está a pé ou de carro $^{39}$. Dessa forma, essa divisão em zonas é muito significativa, na medida em que conta com marcos de sua existência presentes na paisagem da cidade. Contudo, ao se comparar percebe-se que esta divisão também não é compatível com as anteriores. A regionalização da SPTrans não é compatível sequer com a divisão do município em distritos e prefeituras regionais.

\footnotetext{
${ }^{38} \mathrm{O}$ Centro Expandido foi criado para implantar o programa de restrição à circulação de veículos automotores (o "rodízio" de automóveis). Ele é delimitado pelo Mini Anel Viário que compreende o perímetro formado pelas vias Marginal do Rio Tietê, Marginal do Rio Pinheiros, Avenida dos Bandeirantes, Avenida Afonso D'Escragnole Taunay, Complexo Viário Maria Maluf, Avenida Presidente Tancredo Neves, Avenida das Juntas Provisórias, Viaduto Grande São Paulo, Avenida Professor Luís Inácio de Anhaia Melo e Avenida Salim Farah Maluf (SÃO PAULO [Município], Decreto nº 37.085, 1997) .

39 Informações com base na notícia Ruas de São Paulo ganham novas placas de identificação da Secretaria Executiva de Comunicação (PMSP - SECOM), no portal da PMSP em 05 de fevereiro de 2007. Disponível em: <http://www.prefeitura.sp.gov.br/cidade/secretarias/comunicacao/noticias/?p=129454>. Acesso em: 25 jan. 2016.
} 
Figura 6 - Placas de identificação de ruas em São Paulo

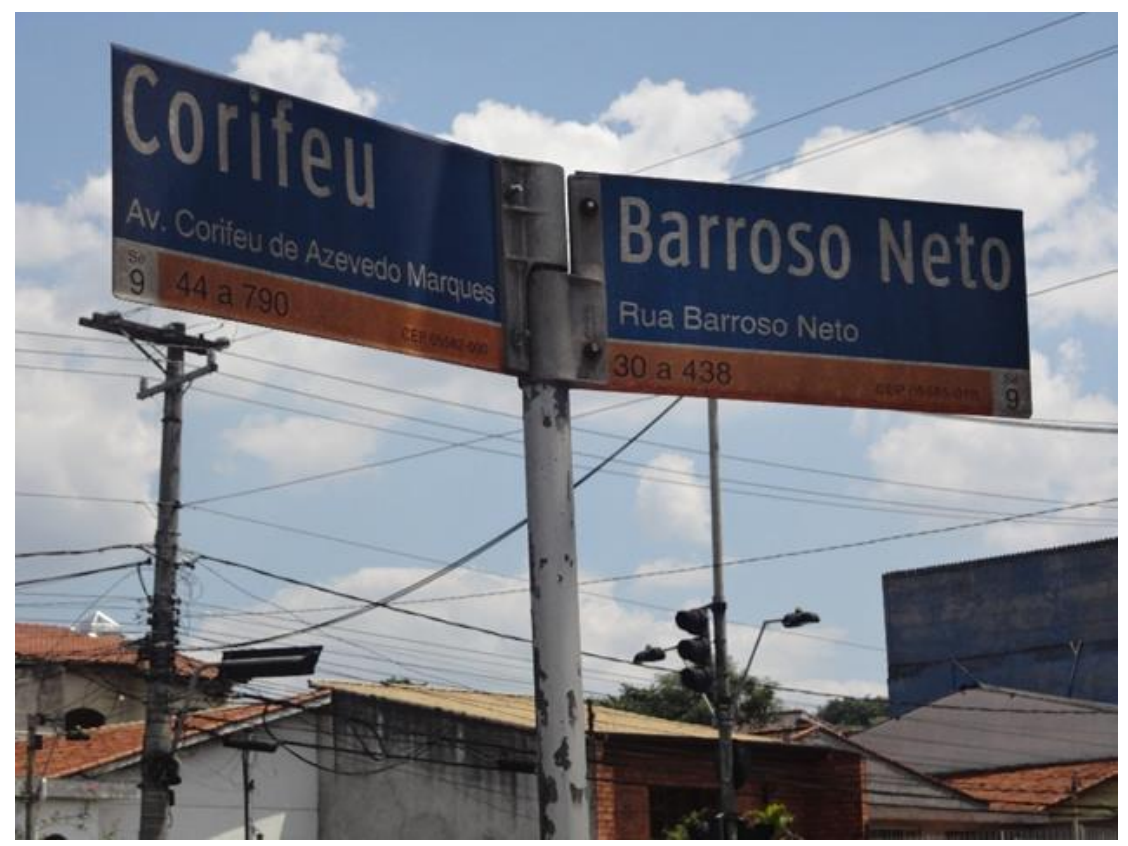

Fonte: Acervo do autor.

Nota: A margem inferior está colorida com a cor laranja, que sinaliza que as ruas pertencem à Zona Oeste, segundo a regionalização da SPTrans.

A partir da comparação de algumas das principais divisões do município em zonas cardeais, referências fundamentais de localização na cidade de São Paulo, percebe-se que não há uma normatização uniforme que padronize uma divisão de grandes zonas para todo o âmbito municipal. Ao contrário disso, prevalece a pluralidade e incompatibilidade de compartimentações - mesmo quando nos atemos às elaboradas pelo Estado. Também é possível observar que a divisão territorial é um processo que ocorre constantemente. As divisões territoriais do município, como já explicitado, acabam não se estabelecendo enquanto referenciais plenamente satisfatórios nem para o poder público e nem para o restante da população. Em 2002, o governo do Município de São Paulo instituiu as subprefeituras como uma tentativa de reestruturar a gestão territorial municipal, procurando ao mesmo tempo aumentar a participação da população no governo, descentralizar a administração pública e integrar os diversos serviços setoriais - o que poderia reduzir ou ao menos racionalizar a malha de divisões territoriais. Passada mais de uma década da implementação das subprefeituras, percebe-se que o quadro territorial paulistano aparentemente permanece numeroso e com diversas incompatibilidades de limites. 
Muitos pesquisadores estudaram o território paulistano, seja pelo enfoque geográfico ou por meio de outras disciplinas. Há abordagens que propõem regionalizações do município a partir de sua dinâmica espacial ou de algum critério específico. Entre os que fazem tais proposições, é comum a discordância e a crítica às divisões territoriais feitas pelo Estado. É o caso de Nice Lecoq Müller (1958, p.122) ao propor uma metodologia alternativa de delimitação do centro da cidade de São Paulo: "os limites [...] fixados para atender a finalidades administrativas não correspondem, na verdade, ao que poderemos chamar de realidade geográfica. Daí sermos levados a apelar para outros critérios”. Contudo, diferentemente da proposta dessa autora, no presente trabalho busca-se interpretar as divisões territoriais estatais, e não as que foram elaboradas por pesquisadores ou outros sujeitos sociais - a menos que tais propostas tiverem sido oficializadas pelo Estado. A bibliografia que trata especificamente das divisões territoriais da capital paulista feitas pelo Estado é relativamente escassa. Entre os pesquisadores que abordaram mais profundamente a vasta e desconexa malha de parcelamentos paulistana estão Aldaíza Sposati, José Donizete Cazzolato e Emílio Haddad. Eles procuram por um lado explicar as regionalizações existentes, por outro, propor diretrizes para a padronização do quadro territorial paulistano. Tais autores, ao apresentarem o quadro territorial da capital paulista, não se apoiam em conceitos geográficos que tradicionalmente subsidiam a explicação das divisões territoriais.

Aldaíza Sposati (2001) comenta sobre o quadro territorial da capital paulista no livro Cidade em Pedaços, nome que sugere tanto a existência de diferentes níveis de cidadania em São Paulo quanto as numerosas compartimentações do município. No livro, são apresentadas e brevemente descritas muitas das divisões territoriais do município, de acordo com o órgão que a realizou e o número de unidades. A maioria dessas divisões elencadas por Sposati consta no Quadro 1:

Quadro 1 - Divisões territoriais de órgãos públicos para gerência de serviços e coleta de dados do Município de São Paulo

\begin{tabular}{|l|l|l|l|}
\hline $\begin{array}{c}\text { Nível } \\
\text { Federativo } \\
\text { do Órgão }\end{array}$ & \multicolumn{1}{|c|}{ Órgão } & \multicolumn{1}{|c|}{ Nome das Unidades Territoriais } & \multicolumn{1}{|c|}{$\begin{array}{c}\mathbf{N}^{\mathbf{0}} \text { de } \\
\text { Unidades }\end{array}$} \\
\hline \multirow{4}{*}{$\begin{array}{l}\text { Municipal } \\
\text { (SP) }\end{array}$} & PMSP (1) & Bairros & 2.489 \\
\cline { 2 - 4 } & PMSP - SAR (2) & Distritos & 96 \\
\cline { 2 - 4 } & PMSP - SIS (3) & Subprefeituras & 32 \\
\cline { 2 - 4 } & PMSP - SMDU (4) & Regiões & 5 \\
\hline
\end{tabular}




\begin{tabular}{|l|l|l|l|}
\hline \multirow{5}{*}{} & PMSP - SF (5) & Setores Fiscais & 309 \\
\cline { 2 - 4 } & PMSP - SME (6) & Diretorias Regionais de Ensino & 13 \\
\cline { 2 - 4 } & PMSP - SMS (7) & Coordenadorias Regionais de Saúde & 5 \\
\cline { 2 - 4 } & CET $(8)$ & Áreas das Gerências de Engenharia de Tráfego & 6 \\
\cline { 2 - 4 } & CET $(9)$ & Regiões do Mapa do Trânsito & 5 \\
\cline { 2 - 4 } & SPTrans $(10)$ & Zonas (Áreas de Concessão) e Centro & 9 \\
\hline \multirow{5}{*}{$\begin{array}{l}\text { Estadual } \\
\text { SP) }\end{array}$} & Metrô $(11)$ & Zonas da Pesquisa de Origem/Destino & 320 \\
\cline { 2 - 4 } & Sabesp (12) & Áreas de Gerência & 19 \\
\cline { 2 - 4 } & Eletropaulo (13) & Áreas das Superintendências & 6 \\
\cline { 2 - 4 } & Telefônica (14) & Áreas de Influência das Estações Telefônicas & 112 \\
\cline { 2 - 4 } & Polícia Civil-SP $(15)$ & Distritos Policiais & 103 \\
\cline { 2 - 4 } & CGJ-SP $(16)$ & Distritos e Subdistritos dos Cartórios de Registro Civil & 58 \\
\cline { 2 - 4 } & TJ-SP $(17)$ & Foros Regionais e Foro Central & 18 \\
\cline { 2 - 4 } & TRE-SP $(18)$ & Zonas Eleitorais & 58 \\
\hline \multirow{5}{*}{ Federal } & IBGE $(19)$ & Áreas de Ponderação & 456 \\
\cline { 2 - 4 } & Correios $(20)$ & Sub-regiões Postais & 6 \\
\hline
\end{tabular}

Fonte: Cazzolato (2005); CET; Cortez et al. (2012); Metrô (2008); Estadão Dados (2012); PMSP - SMDU (2014); São Paulo (Estado) (Lei Complementar no 1.108, 2010); São Paulo (Município) (Lei no 11.220, 1992); São Paulo (Município) (Lei nº 15.764, 2013); PMSP - SME; PMSP - SMS; SPTRANS; Sposati (2001).

Notas:

Quadro produzido pelo autor com base nas informações de Sposati (2001). Quando houve disponibilidade de dados, atualizou-se as informações. As divisões referentes às notas (3), (4), (6), (7), (9), (10) e (20) não constavam no livro de Sposati.

(1) A divisão de São Paulo em bairros é citada por Sposati (2001), no entanto não se especifica qual o órgão da prefeitura que a elaborou e nem qual diploma legal que a instituiu. Não se encontrou dados recentes sobre essa divisão.

(2) Compartimentação feita por iniciativa antiga Secretaria das Administrações Regionais (PMSP - SAR).

(3) A Secretaria de Implementação das Subprefeituras (PMSP - SIS) deixou de existir assim que as subprefeituras foram definitivamente organizadas.

(4) Conforme o Mapa 1 (p.25).

(5) Estabelecidos pela Secretaria Municipal de Finanças e Desenvolvimento Econômico (PMSP - SF) para regular a cobrança do Imposto Predial Territorial Urbano (IPTU). Os setores fiscais são agregações dos lotes e quadras fiscais. Dado referente ao livro de Sposati (2001).

(6) A Secretaria Municipal da Educação (PMSP - SME) divide o município em 13 diretorias regionais de ensino e em 477 setores educacionais para facilitar a administração das unidades escolares.

(7) Áreas de gerência da Secretaria Municipal da Saúde (PMSP - SMS) formadas por agregação de subprefeituras. (8) Cinco dessas Gerências são responsáveis por organizar o tráfego em áreas determinadas, entretanto uma delas é responsável por uma rede de avenidas, e não por uma área. Trata-se da Gerência que é responsável por ordenar o tráfego das vias Marginal Tietê, Marginal Pinheiros, Avenida dos Bandeirantes, além das pontes e viadutos que cortam essas vias.

(9) Conforme a Figura 2 (p.28).

(10) Conforme a Figura 3 (p.29).

(11) A pesquisa Origem/Destino do Metrô é realizada a cada 10 anos, desde 1967, e constitui importante fonte de informação sobre os deslocamentos da população da Região Metropolitana de São Paulo (RMSP) (METRÔ, 2008). (12) Trata-se de áreas das Gerências da Companhia de Saneamento Básico do Estado de São Paulo (Sabesp), segundo Sposati (2001).

(13) A Eletricidade de São Paulo S.A. (Eletropaulo) foi fragmentada em várias empresas em 1997, como parte de um processo de privatização. A distribuição de energia ficou sob controle da AES Corp. desde 2001, momento em que o nome da empresa foi substituído para AES Eletropaulo (AES ELETROPAULO, 2013). Subentende-se que 
as informações disponibilizadas por Sposati (2001) sobre as Superintendências estejam desatualizadas em relação à reestruturação da empresa.

(14) A Telefônica presta serviços de telefonia fixa no Estado de São Paulo.

(15) A Polícia Civil do Estado de São Paulo divide o território em distritos policiais, sediados em delegacias. A Polícia Civil não é, a rigor, um órgão estadual, pois não faz parte do poder executivo ou legislativo. Entretanto, a instituição organiza-se em nível estadual. O mesmo é válido para os itens (16), (17) e (18).

(16) A iniciativa da criação de cartórios de registro civil de pessoas naturais é da Corregedoria Geral de Justiça do Estado de São Paulo (CGJ-SP) (SPOSATI, 2001). Na capital paulista, as circunscrições dos cartórios são os subdistritos e os distritos.

(17) A comarca da capital paulista divide-se em foros regionais para a administração da justiça de primeira instância. As compartimentações ocorrem por iniciativa do Tribunal de Justiça do Estado de São Paulo (TJ-SP) (18) A organização das eleições na capital e no estado é de responsabilidade do Tribunal Regional Eleitoral do Estado de São Paulo (TRE-SP). As Zonas Eleitorais ficam sob jurisdição de juízes eleitorais, e são subdivididas em Seções Eleitorais.

(19) Optou-se por mostrar as Áreas de Ponderação por serem mais amplas, constituindo-se de agregações dos Setores Censitários paulistanos. Tais divisões são usadas nas pesquisas do IBGE, como o Censo Demográfico.

(20) Conforme a Figura 1 (p.27).

O Quadro 2 representa uma amostra significativa das divisões territoriais da capital paulista utilizadas por órgãos públicos. Segundo Sposati (2001), esse panorama de compartimentações indica uma falta de integração das políticas públicas em São Paulo. Além disso, a autora sugere que este problema dificulta o acesso às informações pela população, bem como demonstra a despreocupação do Estado com a participação popular na gestão da cidade. Tal posicionamento verifica-se pela constatação de que muitas secretarias e órgãos municipais possuem divisões territoriais próprias, as quais nem sempre estão compatibilizadas com a divisão distrital - a qual seria a base territorial fundamental da capital paulista.

Posição semelhante é defendida por Cazzolato (2005, p.60), que comenta que as múltiplas divisões do Município de São Paulo refletem "um crônico problema de gestão pública, que, tradicionalmente, no Brasil, toma o caminho das decisões e soluções isoladas setorialmente". Este mesmo autor assinala que a indefinição das divisões territoriais intramunicipais prejudica o processo de apropriação e identificação dos cidadãos com o lugar, por conseguinte a atuação política também fica comprometida (CAZZOLATO, 2005).

Assim, os dois autores constatam que o número de divisões territoriais do município tem como uma de suas principais determinantes a predominância da administração pública setorial e ressaltam os prejuízos que a falta de referências territoriais podem acarretar ao exercício da cidadania. Além disso, ambos concordam que a complexa e múltipla malha territorial do município torna-se indecifrável não só para a maioria da população, mas também para os próprios agentes da administração pública. "Como se pode registrar, o trato do espaço intraurbano de São Paulo foi pouco conhecido da história da cidade e ainda o é” (SPOSATI, 2001, p.35). 
Ao fazer tais análises Sposati e Cazzolato utilizam-se de critérios para classificar as divisões territoriais do Município de São Paulo, apesar de não ser o foco de suas pesquisas. A exposição das compartimentações paulistanas por Sposati pode ser interpretada de duas maneiras. De um lado, ela agrupa as divisões que constituem coordenadas, cadastros ou referências de uso e ocupação do solo da cidade. Nessa categoria, estão incluídos, por exemplo, os Setores Fiscais (incluindo as quadras e lotes fiscais), as divisões do IBGE, as unidades de Origem/Destino do Metrô, os bairros, o cadastro dos logradouros municipais e o zoneamento estabelecido pelos Planos Diretores. Há ainda a menção às Paróquias - divisão eclesiástica do município - o que de certa forma destoa das compartimentações anteriores.

De outro lado, Sposati agrupa as áreas gerenciais, parcelamentos utilizados para a gestão de serviços públicos. Entre esses, estão incluídas as divisões da CET, o CEP, as administrações regionais (posteriormente substituídas por subprefeituras), as áreas gerenciais da Sabesp, Eletropaulo e Telefônica, os distritos policiais, foros regionais e as divisões para serviços cartoriais.

Cazzolato (2005) é mais sistemático na organização dos parcelamentos de São Paulo. Sua classificação não leva em conta o universo de compartimentações existentes, como fez Sposati, pois se configura como uma proposta de organização territorial do município. Segundo esse pesquisador, as divisões territoriais paulistanas deveriam se estruturar por dois níveis escalares, sendo esses constituídos por dois subníveis: o regional, constituído pelas zonas cardeais e as subprefeituras (ou administrações regionais), e o local, constituído pelos distritos e bairros. Cazzolato afirma que esse seria o plano original da reestruturação da divisão distrital que ocorreu em São Paulo em 1992. Como não houve a organização desses quatro níveis territoriais, em sua dissertação ele propõe uma metodologia de delimitação de bairros para grandes cidades. Para Cazzolato, a delimitação de bairros seria um imperativo na medida em que propiciaria tanto um instrumento para a gestão pública, por meio da uniformização dos cadastros municipais, quanto uma maneira de afirmação e identificação de comunidades locais, o que poderia facilitar a cidadania.

Dentre a bibliografia encontrada, possivelmente a classificação mais rigorosa das divisões territoriais paulistanas tenha sido empreendida por Emílio Haddad (1987), em sua tese intitulada Sobre o Estudo da Divisão da Cidade em Zonas Homogêneas: Aplicação para o Município de São Paulo. Embora não faça uma crítica como os autores anteriormente citados, 
Haddad analisa as divisões territoriais do município pelo ponto de vista das elaborações de zoneamentos homogêneos, da maneira como são conceituados pela Geografia Quantitativa.

Dessa forma, encontra-se na tese de Haddad (1987, p.61) uma proposta de agrupamento das divisões territoriais da capital paulista em dois tipos principais: "as feitas 'de cima para baixo' e as feitas 'de baixo para cima'”, com base nos critérios de regionalização da Geografia Quantitativa. O caminho “de cima para baixo” é equivalente à divisão lógica, na qual parte-se "do universo, ou seja, do conjunto dos elementos, dividindo-os em grupos cada vez menores, seguindo as regras da lógica formal" (HADDAD, 1987, p.19). O caminho "de baixo para cima", ao contrário, "parte dos indivíduos que são juntados em subconjuntos cada vez maiores" (HADDAD, 1987, p.19).

As divisões “de cima para baixo" se originam de necessidades político-administrativas ou funcionais. Geralmente têm limites bem definidos, justapõem-se e "servem como unidades espaciais para a organização dos dados referentes às funções para as quais foram estabelecidas" (HADDAD, 1987, p.61). Nessa categoria, Haddad inclui as administrações regionais, o cadastro fiscal (setores e quadras fiscais), o zoneamento da pesquisa origem/destino do Metrô, o CEP, os foros regionais, as circunscrições imobiliárias (não explicadas pelo autor), os distritos policiais, os distritos eleitorais (zonas eleitorais), as paróquias da Igreja Católica e o zoneamento de uso e ocupação do solo (segundo o Plano Diretor de 1972) - este último uma divisão funcional, enquanto os demais são político-administrativos (HADDAD, 1987).

As divisões "de baixo para cima" seriam menores, sem limites fixos e obtidas por agregação de unidades. É nessa classe em que se encontram as compartimentações que mais interessam ao autor, pois se tratam de divisões homogêneas, muitas resultados de diagnósticos e pesquisas sobre o território paulistano, principalmente sobre valores imobiliários da cidade. Curiosamente, Haddad (1987, p.68) inclui nessa categoria a divisão em bairros, pois "na conceituação de um bairro está embutida a ideia de homogeneidade, que se traduz em geral por uma identidade temática do ambiente físico e sociocultural, que é reconhecível”. Apesar disso, ele reconhece que não há limites formalmente estabelecidos para os bairros paulistanos.

As categorizações dos autores mencionados e o quadro territorial consolidado institucionalmente no Município de São Paulo revelam que há diversos modos possíveis de se referenciar espacialmente na cidade. Mais do que isso, há uma grande dificuldade de se compreender as lógicas municipais de compartimentação e organização dos limites territoriais. Nesses termos, percebe-se que se nem mesmo o Estado consegue estabelecer referências 
espaciais padronizadas para utilizar na gestão pública, os cidadãos isoladamente têm ainda menos possibilidades de compreender esses referenciais.

No que diz respeito aos conselhos participativos municipais, seria a confusão em relação às áreas de atuação e às atribuições das prefeituras regionais comparando com secretarias setoriais, ou ainda a dúvida quanto aos assuntos que competem aos diferentes conselhos municipais temáticos. Contudo, os relatos dos conselheiros consultados para essa pesquisa mostraram que eles não julgam que a pluralidade de órgãos administrativos - e seus consequentes quadro territoriais - atrapalham no exercício de participação nos conselhos. Apesar disso, um caso recente muito emblemático do potencial que a confusão de arranjos territoriais diversos podem gerar ocorreu no último processo eleitoral dos CPM, em 2017, na qual a diferença entre as áreas das prefeituras regionais e as zonas eleitorais causou transtornos aos eleitores - houve casos de eleitores que desistiram de votar por não encontrarem exatamente o local de votação ${ }^{40}$. Esse episódio mostra claramente que as referências geográficas possuem alguma relevância para que os munícipes possam exercer de forma mais consciente o seu direito à participação.

${ }^{40}$ CBN. Secretário admite problemas na realização da eleição do conselho participativo de SP. Disponível em <http://cbn.globoradio.globo.com/media/audio/142553/secretario-admite-problemas-na-realizacao-daeleic.htm>. Acesso em: 04 dez. 2017. 


\subsection{A cidade e as condições desiguais de participação política nos conselhos participativos municipais}

Da mesma forma que as divisões territoriais oficiais enquanto referências espaciais, as condições geográficas objetivas da cidade podem impactar o processo participativo no âmbito das prefeituras regionais. Aspectos como a distribuição populacional diferenciada, o acesso desigual a meios de transporte e condições socioeconômicas adversas podem fazer com que parte da sociedade esteja mais favorecida a integrar regularmente instâncias participativas, enquanto parte da população possui obstáculos maiores à participação.

A forma de atuação básica dos conselhos participativos municipais é o comparecimento às reuniões ordinárias, as quais geralmente ocorrem nas sedes das prefeituras regionais. Por esse motivo, um primeiro aspecto para análise é a relação entre a distribuição das pessoas nos territórios da cidade e a localização dos pontos de encontro dos CPM.

\subsubsection{Distribuição demográfica e representatividade por território}

Uma dimensão geográfica a ser considerada sobre a participação política nos CPM é constituída pela distribuição demográfica e representatividade dessas instâncias nos territórios das prefeituras regionais. Cada conselho pretende atuar como fórum representativo das demandas populacionais nos territórios das prefeituras regionais. Nesse sentido, uma primeira questão que se coloca é a adequabilidade da quantidade de população representada por CPM e as eventuais distorções causadas pela desigual distribuição populacional em São Paulo.

A capital paulista tem a maior população do país, com mais de 11 milhões de habitantes. Como a maioria das cidades, a população está distribuída de maneira desigual no território municipal, concentrando-se nas periferias. A Tabela 1 mostra os números de população, área e densidade das prefeituras regionais. 
Tabela 1- População Recenseada, Taxas de Crescimento Populacional e Densidade Demográfica nas subprefeituras do Município de São Paulo - 2010

\begin{tabular}{|c|c|c|c|c|}
\hline Unidades Territoriais & População & $\begin{array}{c}\text { Taxas de } \\
\text { Crescimento }\end{array}$ & Área (ha) & $\begin{array}{c}\text { Densidade } \\
\text { (pop/ha) }\end{array}$ \\
\hline Município de São Paulo & 11.253 .503 & 0,76 & 150.900 & 74,58 \\
\hline Campo Limpo & 607.105 & 1,84 & 3.670 & 165,42 \\
\hline Capela do Socorro & 594.930 & 0,54 & 13.420 & 44,33 \\
\hline M'Boi Mirim & 563.305 & 1,51 & 6.210 & 90,71 \\
\hline Itaquera & 523.848 & 0,68 & 5.430 & 96,47 \\
\hline Penha & 474.659 & $-0,03$ & 4.280 & 110,9 \\
\hline Ipiranga & 463.804 & 0,78 & 3.750 & 123,68 \\
\hline Pirituba & 437.592 & 1,14 & 5.470 & 80 \\
\hline Sé & 431.106 & 1,43 & 2.620 & 164,54 \\
\hline Butantã & 428.217 & 1,27 & 5.610 & 76,33 \\
\hline São Mateus & 426.794 & 1,12 & 4.580 & 93,19 \\
\hline Cidade Ademar & 410.998 & 1,03 & 3.070 & 133,88 \\
\hline Freguesia/Brasilândia & 407.245 & 0,38 & 3.150 & 129,28 \\
\hline Itaim Paulista & 373.127 & 0,38 & 2.170 & 171,95 \\
\hline São Miguel & 369.496 & $-0,24$ & 2.430 & 152,06 \\
\hline Vila Mariana & 344.632 & 0,97 & 2.650 & 130,05 \\
\hline Mooca & 343.980 & 1,11 & 3.520 & 97,72 \\
\hline Santana/Tucuruvi & 324.815 & $-0,07$ & 3.470 & 93,61 \\
\hline Casa Verde/Cachoeirinha & 309.376 & $-0,13$ & 2.670 & 115,87 \\
\hline Lapa & 305.526 & 1,22 & 4.010 & 76,19 \\
\hline Vila Maria/Vila Guilherme & 297.713 & $-0,22$ & 2.640 & 112,77 \\
\hline Jaçanã/Tremembé & 291.867 & 1,34 & 6.410 & 45,53 \\
\hline Pinheiros & 289.743 & 0,61 & 3.170 & 91,4 \\
\hline Sapopemba & 284.524 & 0,08 & 1.350 & 210,76 \\
\hline Guaianases & 268.508 & 0,47 & 1.780 & 150,85 \\
\hline Aricanduva/Vila Formosa & 267.702 & 0,03 & 2.150 & 124,51 \\
\hline Vila Prudente & 246.589 & 0,21 & 3.330 & 74,05 \\
\hline Santo Amaro & 238.025 & 0,86 & 3.750 & 63,47 \\
\hline Jabaquara & 223.780 & 0,44 & 1.410 & 158,71 \\
\hline Cidade Tiradentes & 211.501 & 1,04 & 1.500 & 141 \\
\hline Ermelino Matarazzo & 207.509 & 0,12 & 1.510 & 137,42 \\
\hline Perus & 146.046 & 2,96 & 5.720 & 25,53 \\
\hline Parelheiros & 139.441 & 2,29 & 35.350 & 3,94 \\
\hline
\end{tabular}

Fonte: SMDU/Deinfo (2017).

Nota: Valores referentes ao Censo Demográfico de 2010.

Observa-se a partir da tabela que a prefeitura regional com menor população, a de Parelheiros, possui mais de 100.000 habitantes. Isso significa que as regionais paulistanas acomodam mais população que a imensa maioria dos municípios brasileiros. Pode-se tomar como hipótese a ideia de que a quantidade de população por prefeitura regional dificulta sobremaneira a participação massiva de munícipes não-conselheiros nas reuniões dos CPM. 
Imagine-se por exemplo, que 1\% dos habitantes da regional Butantã resolvessem participar de uma reunião do CPM, isso significaria que mais de 4.000 pessoas estariam presentes no encontro. Seria muito difícil encontrar espaços que acomodassem todas essas pessoas e também viabilizar discussões minimamente organizadas e funcionais. As experiências do CPM revelam que a participação de $1 \%$ da população é muito distante da realidade, mas num cenário de maior presença popular nessas instâncias, a proporção de pessoas por CPM deveria ser revisada.

Essa questão de distribuição demográfica torna-se ainda mais problemática quando se considera a representatividade dos territórios das regionais nos CPM. A regra em vigor dos conselhos estabelece que cada distrito deve possuir pelo menos 5 conselheiros, mais uma proporção de 1 conselheiro para 30.000 habitantes e respeitar o teto máximo de 40 conselheiros. Essa distribuição faz com que CPM de regionais muito populosas como Campo Limpo e Capela do Socorro, tenham proporcionalmente direito a menos vagas para CPM do que conselhos de regionais menos habitadas, como a Sé.

Como a distribuição da população no município é muito desigual, há ainda um outro problema locacional a ser considerado: as sedes das prefeituras regionais - locais mais frequentes dos encontros dos CPM - na maioria das vezes não se localizarem nas áreas mais densas dos distritos e bairros. Esse fato agrava-se ao se considerar que algumas das prefeituras regionais com maiores áreas são também aquelas com maior população, é o caso de Capela do Socorro, M’Boi Mirim, Itaquera, Penha, Pirituba, Butantã e São Mateus. Uma prefeitura regional com território grande significa que um determinado número de habitantes teria que se deslocar mais para chegar a uma reunião, por exemplo. Entretanto, há a ressalva de que muitas vezes as regionais estão em proximidades de estruturas viárias importantes nos territórios da cidade, o que facilitaria a média de deslocamento geral no território da prefeitura regional. $\mathrm{O}$ Mapa 5 mostra os distritos com maiores populações e a posição das sedes das prefeituras regionais. 
Mapa 5 - Quantidade de população por distrito do município de São Paulo - 2010

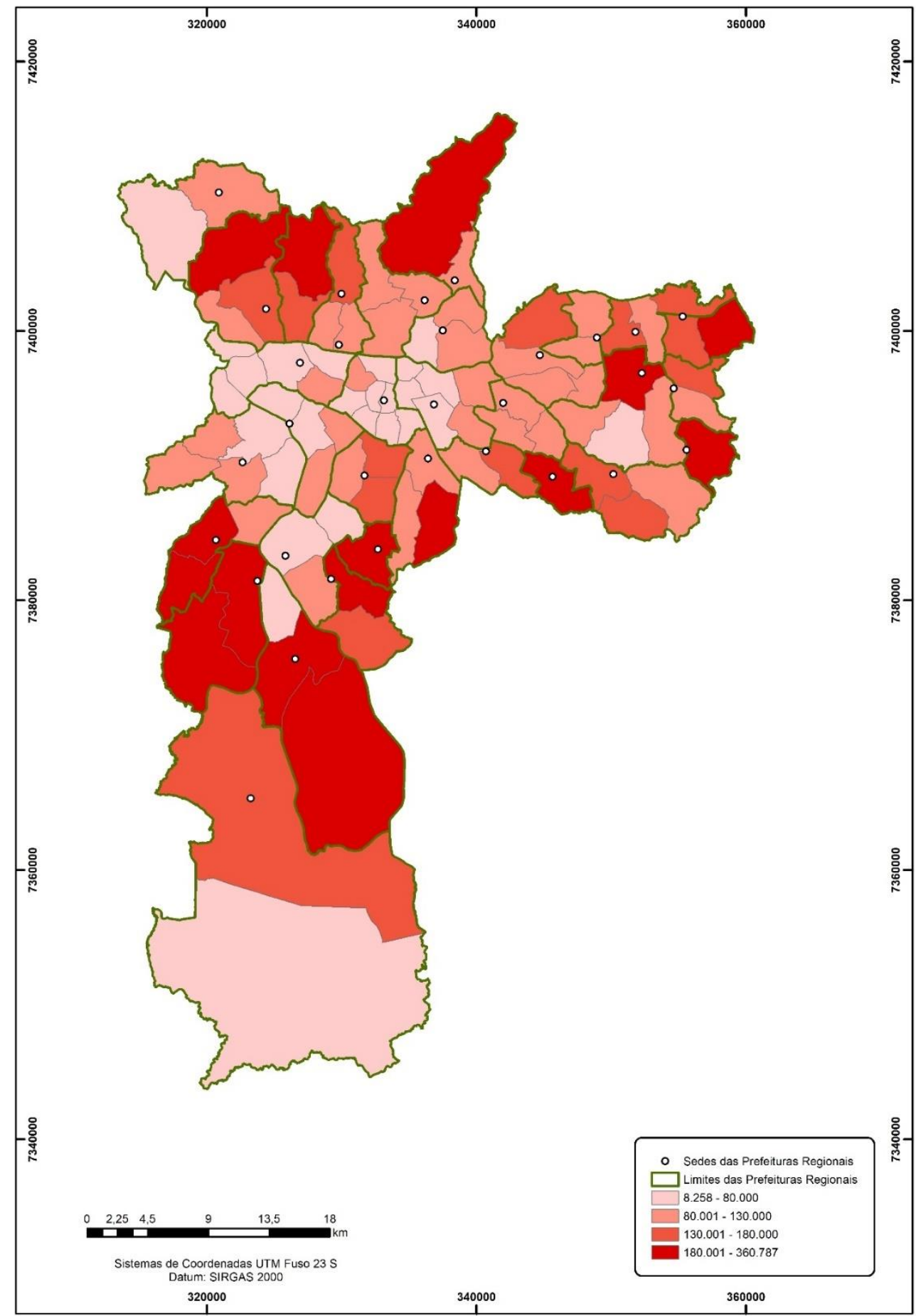

Fonte: PMSP-SMDU; DEINFO (2017). Elaborado pelo autor. 
Considerando a relação entre número de população e prefeituras regionais/CPM, é praticamente impossível haver um canal de comunicação direta e sistemática entre os habitantes de um distrito ou prefeitura regional e os representantes dos CPM, pois o número de conselheiros é muito reduzido diante da quantidade de moradores dos distritos e regionais, além da área a ser percorrida para se chegar aos conselheiros ser, no geral, significativa. Mesmo assim, essa comunicação mais direta entre conselheiros e munícipes ocorre de acordo com a disponibilidade de cada conselheiro, por exemplo, a conselheira Cida que reside na Freguesia do Ó realiza informes sistemáticos das reuniões do CPM que participa na comunidade da igreja que integra, no mesmo bairro. Mas, via de regra, os conselheiros alegaram que não possuem um canal de comunicação sistemático com as pessoas das comunidades que representam.

Essas dificuldades tornam imperativo o papel dos informes das reuniões e discussões dos CPM por vias remotas, como a publicação em canais na internet. Apesar da previsão legal de publicação das atas das reuniões no Diário Oficial do Município (DOM), nem sempre as atas são publicadas em tempo hábil, às vezes demoram meses até ocorrer, além de que a busca desses materiais na página online do DOM é bastante difícil, nem sempre se encontram os resultados esperados. Os conselheiros quando questionados sobre o assunto, em geral, concordaram com o fato de que o DOM não serve como canal de comunicação eficiente com os munícipes. Além disso, a própria ata não é o melhor instrumento de síntese das reuniões, pois por vezes apresenta detalhamentos extensivos dos diálogos. Por esse motivo, alguns CPM ou conselheiros individuais divulgam discussões e pautas de reuniões por meio de perfis em redes sociais, como o Facebook ${ }^{41}$. Grande parte dos CPM possuem perfil no Facebook, entretanto a grande maioria não atualiza regularmente a página. Do mesmo modo, os sites das prefeituras regionais, os quais possuem campos próprios para a participação social e para os CPM, quase nunca estão atualizados com informes e atas de reuniões. Alguns conselheiros quando questionados sobre o assunto alegaram que os sites são de responsabilidade da prefeitura, por isso não são atualizados com frequência. Outro meio de comunicação muito citado nas experiências relatadas pelos conselheiros foi o aplicativo de mensagens por celular Whatsapp, a partir do qual certos conselheiros dialogavam entre si ou repassavam informações a grupos de interesse mais próximos. Para os cidadãos que desejam participar das reuniões dos CPM e não possuem relação pessoal com conselheiros, muitas vezes o único meio disponível de se obter a agenda

\footnotetext{
${ }^{41}$ Entre as páginas no Facebook mais ativas, destaca-se a de Pinheiros: <https://www.facebook.com/ConselhoParticipativo-Municipal-Pinheiros-Exerc\%C3\%ADcio-2015-17-772524606141719/>.
} 
do conselho é entrando em contato telefônico com a prefeitura regional. Entretanto, a disponibilização dessa informação pelos representantes da prefeitura regional nem sempre ocorre, em alguns casos os assessores de gabinete das regionais repassam os números telefônicos dos coordenadores do conselho para que o cidadão obtenha o calendário do CPM diretamente com algum componente do conselho ${ }^{42}$.

Essas observações relativas a dificuldade de repassar as informações das atividades dos CPM mostram um defeito significativo do papel institucional dessa instância. Segundo uma modelagem mais normatizada, deveria haver mecanismos mais sistemáticos de repasse de informações dos CPM aos habitantes dos distritos e regionais. A observação das experiências concretas dos conselheiros mostra que há um esforço por parte dos representantes em tentar informar a população que não é acompanhado pelos dirigentes das prefeituras regionais e do poder público municipal. Para além dessa constatação, destaca-se o fato de que se as unidades territoriais e o número de população representada por CPM fossem menores, seria mais provável que as informações fossem repassadas de maneiras mais capilarizadas e que mais pessoas se interessassem em participar das discussões.

\subsubsection{Situação e acessibilidade dos territórios paulistanos e dos espaços de reunião}

Um dos aspectos geográficos que hipoteticamente facilita ou obstaculiza a presença de pessoas em instâncias participativas é a acessibilidade e a localização relativa dos munícipes aos locais de reunião e encontro. Um raciocínio elementar leva ao entendimento de que quanto maior a área de um determinado recorte territorial, mais difícil seria a acessibilidade média à sua sede - desconsiderando as concentrações específicas de população na unidade, como bairros de alta densidade demográfica. Há ainda o fato de que os territórios muito extensos

\footnotetext{
${ }^{42}$ Em uma das experiências de campo, após entrar em contato telefônico com a Prefeitura Regional de Campo Limpo, nos foi passado uma data de reunião do respectivo CPM. Ao chegar no horário da reunião, no local e dia combinados, houve a surpresa com o fato de que se tratava de uma reunião do CONSEG, e não do CPM. Houve também uma situação, nesta mesma prefeitura regional, em que chegamos na reunião e nos deparamos com apenas dois conselheiros. Após um período de espera, eles entraram em contato com outros integrantes e foram notificados de que a reunião havia sido cancelada naquele mesmo dia, em virtude de um evento organizado pela prefeitura regional.

A incerteza no repasse das informações sobre os CPMs pelas prefeituras regionais era um fenômeno relativamente frequente nas experiências de campo desta pesquisa. Desse maneira, o modo mais seguro de obter a informação é conseguir contato direto com algum participante dos CPMs, especialmente o coordenador ou secretário.
} 
tendem a ter mais núcleos urbanos descontínuos, além de um maior número de bairros, o que hipoteticamente traria a necessidade de um maior número de administrações regionalizadas do Estado. No Município de São Paulo as maiores áreas encontram-se justamente em prefeituras regionais já afastadas das áreas com maior centralidade econômica da cidade - são os casos, por exemplo, de Parelheiros, Capela do Socorro e Jaçanã/Tremembé.

Para amenizar os efeitos da dificuldade de acesso dos conselheiros, alguns CPM adotam revezamento de espaços de reuniões em distritos diferentes. Em alguns casos, como na Prefeitura Regional de Freguesia do Ó/Brasilândia, tratava-se de uma medida sistemática de revezamento, em que os encontros ocorriam em pelo menos três localidades diferentes ${ }^{43}$. Há CPM que adotam reuniões em localidades externas às sedes das prefeituras regionais em momentos específicos, mas sem uma regra sistemática de revezamento.

Um dos fatores cruciais nos momentos de encontro dos CPM são os horários das reuniões. Conforme mencionado no primeiro capítulo (item 1.3), as reuniões em geral são definidas em um mesmo horário de dia da semana para todo o ano. Entretanto, na maioria dos CPM as reuniões acabam ocorrendo no período noturno em algum dia de segunda à sexta, fato que acaba impedindo muitos munícipes de participar. Esse aspecto é agravado ao se levar em conta que os encontros por vezes duram algumas horas, fazendo com que os participantes tenham que se deslocar em horários difíceis do ponto de vista da disponibilidade de transporte público e da insegurança devido a redução do tráfego de veículos e pedestres ${ }^{44}$.

As condições de acessibilidade nos territórios da capital paulista são muito discrepantes entre si, trazendo impactos para o cotidiano das pessoas em todos os níveis, inclusive na participação política. O Mapa 6 e a Tabela 2 a seguir procuram mostrar parte desse problema por meio da duração médias das viagens entre as prefeituras regionais paulistanas:

\footnotetext{
${ }^{43}$ No caso, as localidades eram o Clube da Comunidade Oswaldo Brandão, localizado na Vila Brasilândia; a Casa de Cultura da Brasilândia, em outra localidade do distrito homônimo; e a sede da Prefeitura Regional da Freguesia do Ó Brasilândia - a qual curiosamente situa-se no território da Prefeitura Regional da Casa Verde/Cachoeirinha.

${ }^{44}$ Numa das experiências de campo da pesquisa, estivemos na Prefeitura Regional de Pinheiros, numa reunião de CPM numa quinta-feira que se iniciou às $19 \mathrm{~h} 30$ e durou até às $22 \mathrm{~h} 15$. Apesar da sede da regional ser muito bem localizada, próxima a uma estação de metrô, a esse horário o pedestre precisa passar em plena Marginal Pinheiros - via expressa pouco convidativa a transeuntes - para retornar ao metrô, em um contexto de quase total ausência movimentação de pedestres, em razão do horário avançado, o que traz uma grande sensação de insegurança..
} 
Mapa 6 - Duração média das viagens (min) por distrito do Município de São Paulo 2007

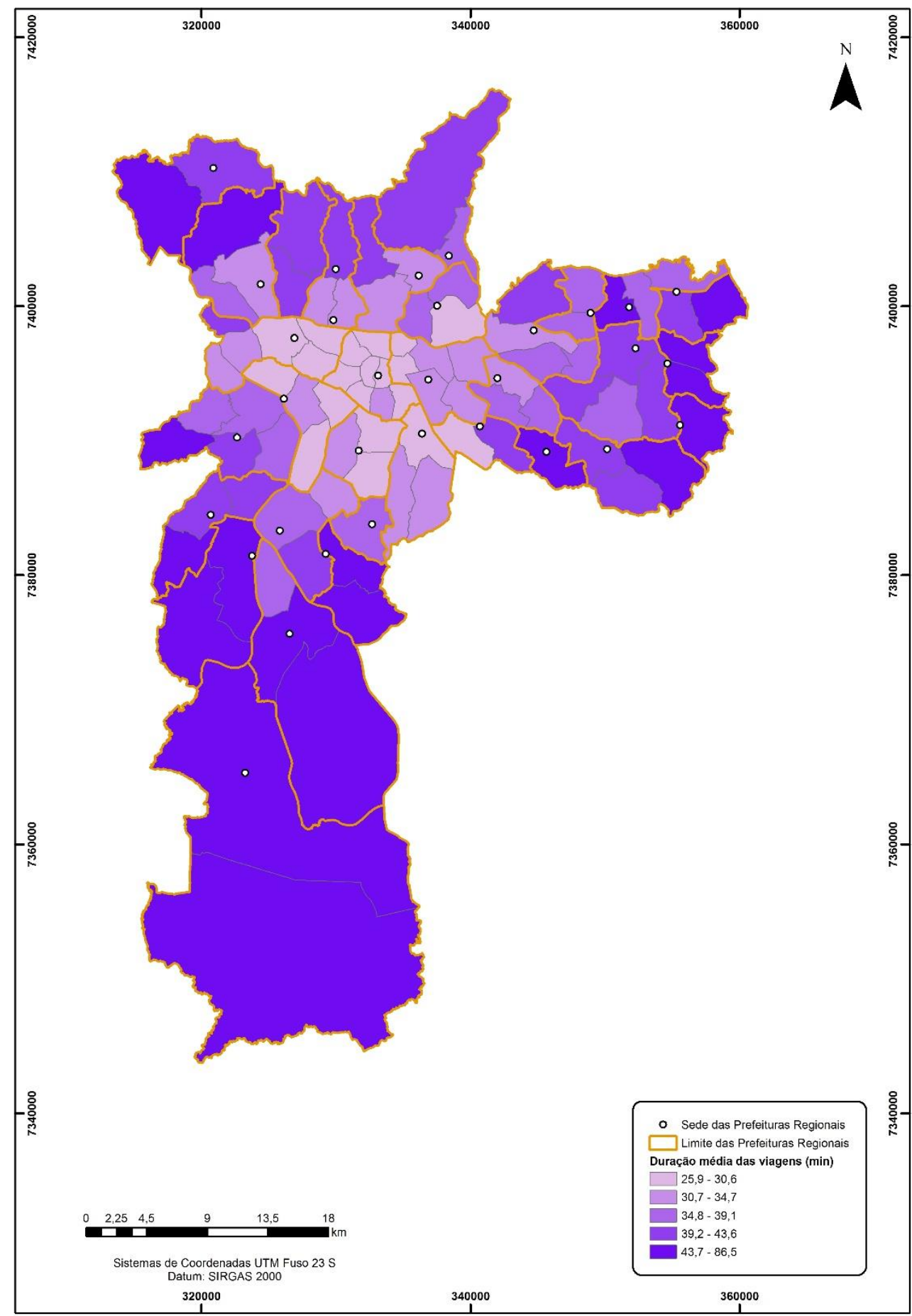

Fonte: Metrô (2008). Elaborado pelo autor.

Nota: A duração média das viagens por distritos foi obtida considerando o fator de expansão da amostra para a variável duração da viagem da pesquisa origem/destino do Metrô. 
Tabela 2 - Duração média das viagens, em minutos, por distritos do Município de

São Paulo - 2007

\begin{tabular}{|c|c|c|c|c|c|}
\hline Posição & Distritos & Duração (min) & Posição & Distritos & Duração (min) \\
\hline & São Paulo & 33,6 & & & \\
\hline $1 \stackrel{0}{0}$ & Marsilac & 86,5 & $51^{\circ} \stackrel{\circ}{ }$ & Morumbi & 36,2 \\
\hline $2^{\circ}$ & Cidade Tiradentes & 63,8 & $52^{\circ}$ & Socorro & 36,1 \\
\hline $3^{\circ}$ & Parelheiros & 59,9 & $53^{\circ}$ & São Miguel & 36,0 \\
\hline $4^{\circ}$ & Jardim Angela & 56,2 & $54^{\circ}$ & Rio Pequeno & 35,9 \\
\hline $5^{\circ}$ & Guaianases & 54,4 & $55^{\circ}$ & Jardim Helena & 35,8 \\
\hline $6^{\circ}$ & Grajaú & 53,3 & $56^{\circ}$ & Vila Medeiros & 35,0 \\
\hline $7^{\circ} \underline{0}$ & Capão Redondo & 52,7 & $57^{\circ}$ & Vila Guilherme & 35,0 \\
\hline $8^{\circ}$ & Lajeado & 50,2 & $58^{\circ}$ & Pirituba & 34,7 \\
\hline 9응 & Jaraguá & 49,6 & $59^{\circ}$ & Belém & 34,2 \\
\hline $10^{\circ}$ & Iguatemi & 49,5 & $60^{\circ}$ & Casa Verde & 34,2 \\
\hline $11^{\circ}$ & Raposo Tavares & 49,4 & $61^{\circ}$ & Campo Belo & 34,0 \\
\hline $12^{\circ}$ & Pedreira & 48,5 & $62^{\circ}$ & Sacomã & 33,9 \\
\hline $13^{\circ}$ & Cidade Ademar & 48,1 & $63^{\circ}$ & Carrão & 33,5 \\
\hline $14^{\circ}$ & Jardim São Luís & 45,8 & $64^{\circ}$ & Jaguaré & 33,4 \\
\hline $15^{\circ}$ & Cidade Dutra & 45,8 & $65^{\circ}$ & Penha & 33,3 \\
\hline $16^{\circ}$ & Itaim Paulista & 44,4 & $66^{\circ}$ & Vila Leopoldina & 33,3 \\
\hline $17^{\circ}$ & Anhanguera & 44,3 & $67^{\circ}$ & Tucuruvi & 33,3 \\
\hline $18^{\circ}$ & Vila Jacuí & 43,9 & $68^{\circ}$ & Agua Rasa & 32,8 \\
\hline $19^{\circ}$ & Sapopemba & 43,7 & $69^{\circ}$ & Santana & 32,7 \\
\hline $20^{\circ}$ & José Bonifácio & 43,6 & $70^{\circ}$ & Limão & 32,3 \\
\hline $21^{\circ}$ & Vila Curuçá & 43,3 & $71^{\circ}$ & Moema & 31,7 \\
\hline $22^{\circ}$ & Campo Limpo & 43,0 & $72^{\circ}$ & Pinheiros & 31,4 \\
\hline $23^{\circ}$ & Cachoeirinha & 42,2 & $73^{\circ}$ & Cursino & 31,3 \\
\hline $24^{\circ}$ & Brasilândia & 41,9 & $74^{\circ}$ & Moóca & 31,2 \\
\hline $25^{\circ}$ & Tremembé & 41,5 & $75^{\circ}$ & Liberdade & 31,2 \\
\hline $26^{\circ}$ & Cidade Líder & 41,1 & $76^{\circ}$ & Tatuapé & 31,1 \\
\hline $27^{\circ} \stackrel{0}{r}-1$ & Jaguara & 41,0 & $77^{\circ} \stackrel{0}{-1}$ & Barra Funda & 30,6 \\
\hline $28^{\circ}$ & Perus & 40,8 & $78^{\circ}$ & Saúde & 30,4 \\
\hline $29^{\circ}$ & Vila Andrade & 40,7 & $79^{\circ}$ & Lapa & 30,3 \\
\hline $30^{\circ}$ & Cangaíba & 40,5 & $80^{\circ}$ & Brás & 30,3 \\
\hline $31^{\circ}$ & Vila Sônia & 40,5 & $81^{\circ}$ & Itaim Bibi & 30,1 \\
\hline $32^{\circ}$ & Mandaqui & 40,4 & $82^{\circ}$ & Vila Maria & 29,9 \\
\hline $33^{\circ}$ & Itaquera & 40,1 & $83^{\circ}$ & Alto De Pinheiros & 29,7 \\
\hline $34^{\circ}$ & São Mateus & 39,7 & $84^{\circ}$ & Santa Cecília & 29,7 \\
\hline $35^{\circ}$ & São Rafael & 39,6 & $85^{\circ}$ & Ipiranga & 29,7 \\
\hline $36^{\circ}$ & São Lucas & 39,6 & $86^{\circ}$ & Jardim Paulista & 29,7 \\
\hline $37^{\circ}$ & Freguesia Do O & 39,5 & $87^{\circ}$ & Cambuci & 29,3 \\
\hline $38^{\circ}$ & Campo Grande & 39,4 & $88^{\circ}$ & Vila Prudente & 29,2 \\
\hline $39 ㅇ$ & Ponte Rasa & 39,1 & $89 ㅇ$ & Consolação & 29,1 \\
\hline $40^{\circ}$ & São Domingos & 38,4 & $90^{\circ}$ & Sé & 28,5 \\
\hline $41^{\circ}$ & Aricanduva & 38,3 & $91^{\circ}$ & Bela Vista & 28,4 \\
\hline $42^{\circ}$ & Ermelino Matarazzc & 38,1 & $92^{\circ}$ & República & 28,2 \\
\hline $43^{\circ}$ & Vila Matilde & 38,0 & $93^{\circ}$ & Pari & 28,0 \\
\hline $44^{\circ}$ & Artur Alvim & 37,8 & $94^{\circ}$ & Perdizes & 27,2 \\
\hline $45^{\circ}$ & Santo Amaro & 37,6 & $95^{\circ}$ & Vila Mariana & 26,8 \\
\hline $46^{\circ}$ & Parque Do Carmo & 36,9 & $96^{\circ}$ & Bom Retiro & 25,9 \\
\hline $47^{\circ}$ & Jaçanã & 36,8 & & & \\
\hline $48^{\circ}$ & Jabaquara & 36,7 & & & \\
\hline $49^{\circ}$ & Vila Formosa & 36,6 & & & \\
\hline $50^{\circ}$ & Butantã & 36,4 & & & \\
\hline
\end{tabular}

Fonte: Metrô (2008). Elaborado pelo autor.

Nota: A duração média das viagens por distritos foi obtida considerando o fator de expansão da amostra para a variável duração da viagem da pesquisa origem/destino do Metrô. 
O quadro mostrado pelo Mapa 6 e pela Tabela 2 revela uma profunda desigualdade nos tempos médios de viagens por pessoa nos distritos - para qualquer assunto e por qualquer meio de transporte. Alguns dos distritos com piores indicadores sociais são justamente os que são mais distantes do ponto de vista relativo ao tempo de viagem. Os moradores do Distrito de Cidade Tiradentes, por exemplo, levam em média o dobro do tempo em viagens em comparação com os habitantes do Distrito Itaim Bibi. Os tempos de deslocamento menores que os moradores de localidades mais centrais possuem, gera mais tempo livre, o qual pode ser dispendido em diversas atividades, incluindo a participação em associações políticas ou numa instância como o CPM. Por outro lado, moradores de distritos como Marsilac, Parelheiros, Cidade Tiradentes, Jardim Ângela, Guaianases, entre outros, acabam por ter menos tempo livre disponível para realizar qualquer tipo de atividade tanto na reprodução de suas vidas quanto para a associação em atividades como as do CPM.

Uma questão que não pode ser esquecida é o fato de que os deslocamentos, para qualquer fim, têm um custo - seja para quem se desloca por transporte público ou por automóveis particulares. Como as localidades com pior acessibilidade relativa são justamente aquelas que possuem piores índices socioeconômicos (ver item 2.2.3), esse quadro pode gerar uma disparidade no potencial de participação das unidades territoriais. O governo municipal chegou a propor como alternativa a esse problema a concessão de uma cota mensal de créditos de passagens de ônibus aos conselheiros. Um decreto relativo a isso foi aprovado em $2016^{45}$, mas nunca chegou a ser cumprido, motivo de constante reclamação por parte dos conselheiros ativos.

Apesar da reclamação relativa ao não cumprimento da concessão dos créditos de transporte público, no geral, os conselheiros ativos consultados no decorrer dessa pesquisa não relataram a acessibilidade como um problema decisivo para a ausência de conselheiros e munícipes nas reuniões dos CPM.

\subsubsection{Desigualdades socioeconômicas entre as populações e territórios das regionais}

As áreas das prefeituras regionais dispõem de situação muito desigual do ponto de vista socioeconômico. Diversos indicadores sociais poderiam ser utilizados para verificar essa

${ }^{45}$ São Paulo [Município], Decreto n ${ }^{\circ}$ 56.933, 2016. 
situação, mas três deles são bastante representativos das discrepâncias no município: a formação educacional, a renda per capita e o IDH - a distribuição geográfica desses indicadores podem ser vistos nos mapas e tabelas a seguir.

Tabela 3 - Percentual da população de 18 anos ou mais com ensino médio completo por prefeituras regionais do Munícipio de São Paulo - 2010

\begin{tabular}{|c|c|c|}
\hline Posição & Prefeitura Regional & Percentual (\%) \\
\hline $1^{\circ}=$ & Pinheiros & 82,21 \\
\hline $2^{\circ}$ & Vila Mariana & 81,35 \\
\hline $3^{\circ}$ & Santo Amaro & 71,61 \\
\hline $4^{\circ}$ & Lapa & 70,28 \\
\hline $5^{\circ}$ & Sé & 67,98 \\
\hline $6^{\circ}$ & Santana/Tucuruvi & 63,03 \\
\hline $7^{\circ}$ & Mooca & 61,16 \\
\hline $8^{\circ}$ & Butantã & 58,15 \\
\hline 90 & Ipiranga & 53,07 \\
\hline $10^{\circ}$ & Jabaquara & 51,80 \\
\hline $11^{\circ}$ & Aricanduva/Vila Formosa & 51,35 \\
\hline $12^{\circ}$ & Penha & 51,23 \\
\hline $13^{\circ}$ & Casa Verde & 48,93 \\
\hline $14^{\circ}$ & Ermelino Matarazzo & 47,75 \\
\hline $15^{0}$ & Pirituba/Jaraguá & 47,62 \\
\hline $16^{\circ}$ & Vila Maria/Vila Guilherme & 46,97 \\
\hline $17^{\circ}$ & Vila Prudente & 43,78 \\
\hline $18^{0}$ & Jaçanã/Tremembé & 42,83 \\
\hline $19^{\circ}$ & Itaquera & 42,71 \\
\hline $20^{\circ}$ & Freguesia Do Ó/Brasilândia & 41,52 \\
\hline $21^{\circ}=$ & Campo Limpo & 41,36 \\
\hline $22^{\circ}$ & Capela Do Socorro & 38,93 \\
\hline $23^{\circ}$ & São Miguel Paulista & 38,17 \\
\hline $24^{\circ}$ & Cidade Ademar & 37,12 \\
\hline $25^{\circ}$ & Itaim Paulista & 36,52 \\
\hline $26^{\circ}$ & Perus & 36,43 \\
\hline $27^{\circ}$ & M'Boi Mirim & 34,34 \\
\hline $28^{\circ}$ & Cidade Tiradentes & 33,76 \\
\hline $29^{\circ}$ & São Mateus & 33,62 \\
\hline $30^{\circ}$ & Guaianases & 32,95 \\
\hline $31^{\circ}$ & Parelheiros & 27,12 \\
\hline
\end{tabular}

Fonte: IPEA et al., 2014. Elaborado pelo autor.

Nota: A variável foi calculada a partir da razão entre a população de 18 anos ou mais de idade que concluiu o ensino médio, em qualquer de suas modalidades (regular seriado, não seriado, EJA ou supletivo) e o total de pessoas nesta faixa etária, multiplicada por 100. Foram consideradas como tendo concluído o ensino médio as pessoas frequentando a $4^{a}$ série desse nível. 
Mapa 7 - Percentual da população de 18 anos ou mais com ensino médio completo por prefeituras regionais do Munícipio de São Paulo - 2010

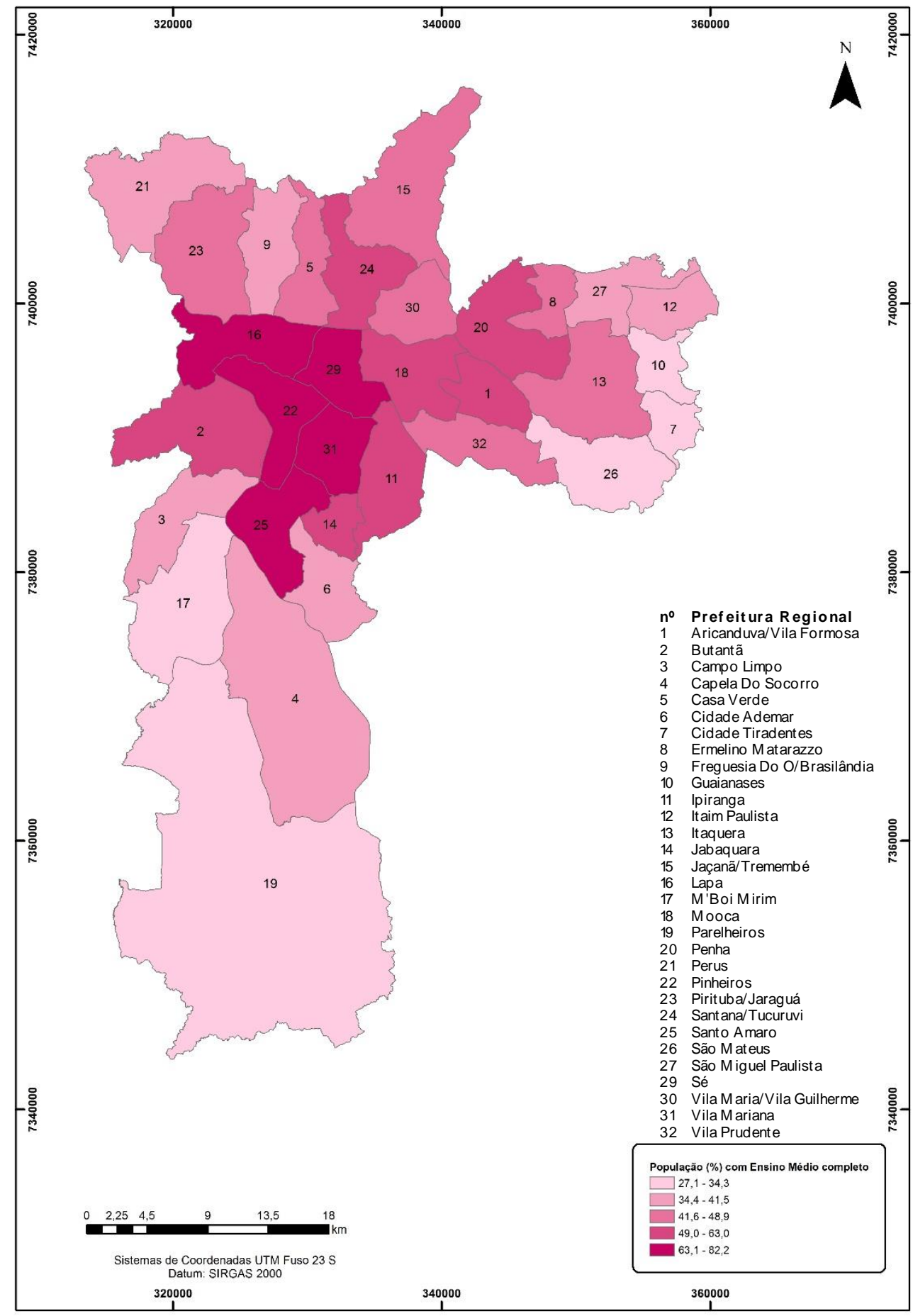

Fonte: IPEA et al., 2014. Elaborado pelo autor. 
Tabela 4 - Renda per capita média (R\$) por prefeituras regionais do Município de São Paulo - 2010

\begin{tabular}{|c|c|c|}
\hline Posição & Prefeitura Regional & Renda (R\$) \\
\hline 10 & Pinheiros & 6.126 \\
\hline $2^{\circ}$ & Vila Mariana & 5.065 \\
\hline $3^{\circ}$ & Santo Amaro & 3.688 \\
\hline $4^{\circ}$ & Lapa & 3.469 \\
\hline $5^{\circ}$ & Sé & 2.895 \\
\hline $6^{\circ}$ & Butantã & 2.635 \\
\hline $7^{\circ}$ & Mooca & 2.262 \\
\hline $8^{\circ}$ & Santana/Tucuruvi & 2.135 \\
\hline $9^{\circ}$ & Jabaquara & 1.539 \\
\hline $10^{\circ}$ & Ipiranga & 1.482 \\
\hline $11^{\circ}$ & Aricanduva/Vila Formosa & 1.411 \\
\hline $12^{\circ}$ & Campo Limpo & 1.236 \\
\hline $13^{\circ}$ & Casa Verde & 1.105 \\
\hline $14^{\circ}$ & Vila Maria/Vila Guilherme & 1.073 \\
\hline $15^{\circ}$ & Penha & 1.064 \\
\hline $16^{\circ}$ & Pirituba/Jaraguá & 989 \\
\hline $17^{\circ}$ & Vila Prudente & 980 \\
\hline $18^{\circ}$ & Cidade Ademar & 972 \\
\hline $19^{\circ}$ & Jaçanã/Tremembé & 893 \\
\hline $20^{\circ}$ & Freguesia Do Ó/Brasilândia & 841 \\
\hline $21^{\circ}$ & Ermelino Matarazzo & 838 \\
\hline $22^{\circ}$ & Capela Do Socorro & 824 \\
\hline $23^{\circ}$ & Itaquera & 785 \\
\hline $24^{\circ}$ & São Mateus & 674 \\
\hline $25^{\circ}$ & São Miguel Paulista & 642 \\
\hline $26^{\circ}$ & M'Boi Mirim & 624 \\
\hline $27^{\circ}$ & Perus & 615 \\
\hline $28^{\circ}$ & Itaim Paulista & 588 \\
\hline $29^{\circ}$ & Guaianases & 554 \\
\hline $30^{\circ}$ & Cidade Tiradentes & 517 \\
\hline $31^{\circ}$ & Parelheiros & 500 \\
\hline
\end{tabular}

Fonte: IPEA et al., 2014. Elaborado pelo autor.

Nota: A variável foi calculada a partir da razão entre o somatório da renda de todos os indivíduos residentes em domicílios particulares permanentes e o número total desses indivíduos. Valores em reais de 01/agosto de 2010 
Mapa 8 - Renda per capita média (R\$) por prefeituras regionais do Município de São

Paulo - 2010

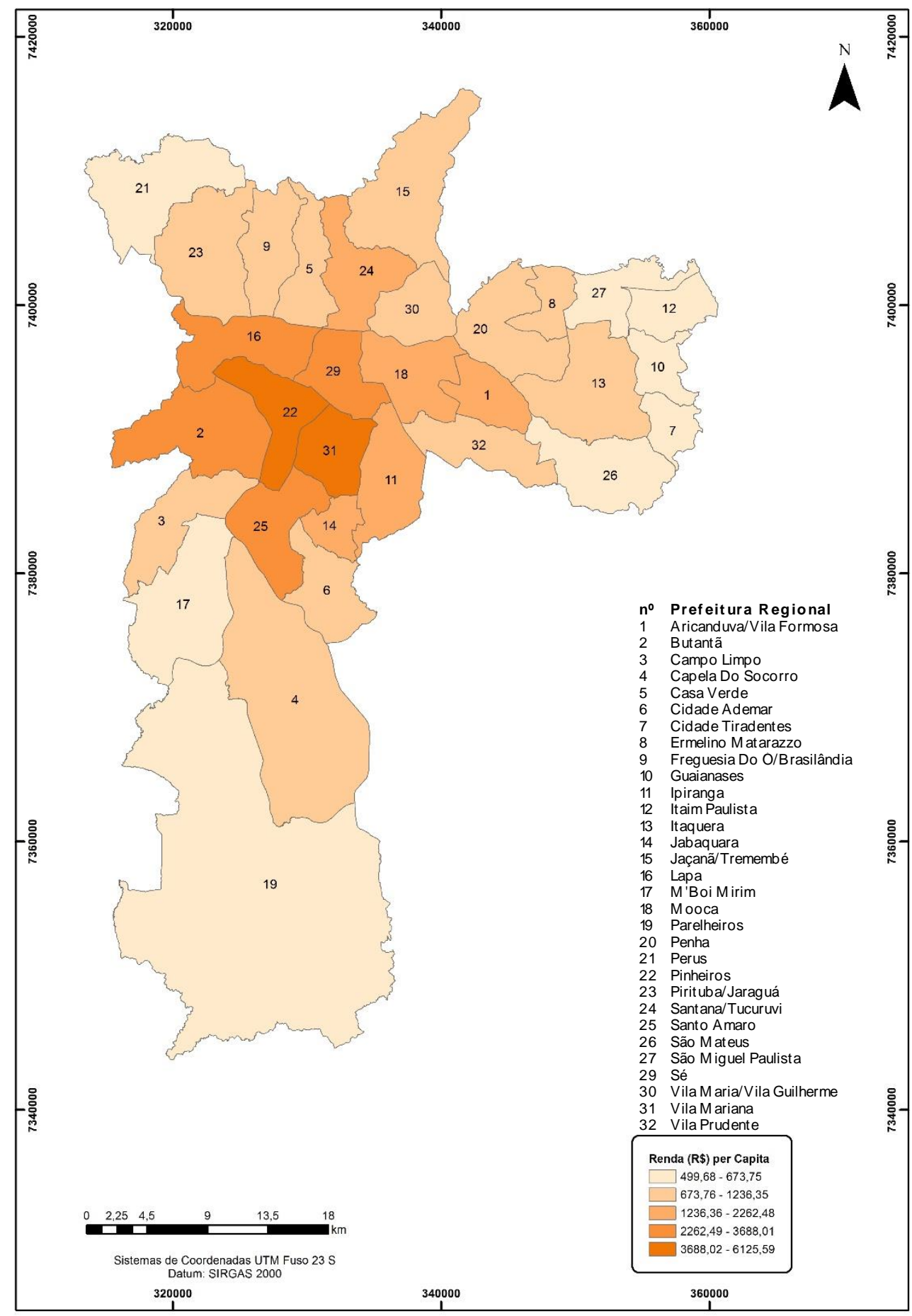

Fonte: IPEA et al., 2014. Elaborado pelo autor. 
Tabela 5 - Índice de Desenvolvimento Humano Municipal por prefeitura regional do

Município de São Paulo- 2010

\begin{tabular}{|c|c|c|}
\hline Posição & Prefeitura Regional & IDH-M \\
\hline 10 & Pinheiros & 0,942 \\
\hline $2^{\circ}$ & Vila Mariana & 0,938 \\
\hline $3^{\circ}$ & Santo Amaro & 0,909 \\
\hline $4^{\circ}$ & Lapa & 0,906 \\
\hline $5^{\circ}$ & Sé & 0,889 \\
\hline $6^{0}$ & Mooca & 0,869 \\
\hline $7^{\circ}$ & Santana/Tucuruvi & 0,869 \\
\hline $8^{\circ}$ & Butantã & 0,859 \\
\hline $9^{\circ}$ & Ipiranga & 0,824 \\
\hline $10^{\circ}$ & Aricanduva/Vila Formosa & 0,822 \\
\hline $11^{\circ}$ & Jabaquara & 0,816 \\
\hline $12^{\circ}$ & Penha & 0,804 \\
\hline $13^{\circ}$ & Casa Verde & 0,799 \\
\hline $14^{\circ}$ & Vila Maria/Vila Guilherme & 0,793 \\
\hline $15^{\circ}$ & Pirituba/Jaraguá & 0,787 \\
\hline $16^{\circ}$ & Vila Prudente & 0,785 \\
\hline $17^{\circ}$ & Campo Limpo & 0,783 \\
\hline $18^{\circ}$ & Ermelino Matarazzo & 0,777 \\
\hline $19^{\circ}$ & Jaçanã/Tremembé & 0,768 \\
\hline $20^{\circ}$ & Freguesia Do Ó/Brasilândia & 0,762 \\
\hline $21^{\circ}$ & Cidade Ademar & 0,758 \\
\hline $22^{\circ}$ & Itaquera & 0,758 \\
\hline $23^{\circ}$ & Capela Do Socorro & 0,750 \\
\hline $24^{\circ}$ & São Miguel Paulista & 0,736 \\
\hline $25^{\circ}$ & São Mateus & 0,732 \\
\hline $26^{\circ}$ & Perus & 0,731 \\
\hline $27^{\circ}$ & Itaim Paulista & 0,725 \\
\hline $28^{\circ}$ & M'Boi Mirim & 0,716 \\
\hline $29^{\circ}$ & Guaianases & 0,713 \\
\hline $30^{\circ}$ & Cidade Tiradentes & 0,708 \\
\hline $31^{\circ}$ & Parelheiros & 0,680 \\
\hline
\end{tabular}

Fonte: IPEA et al., 2014. Elaborado pelo autor.

Nota: A variável foi calculada a partir da média geométrica dos índices das dimensões Renda, Educação e Longevidade, com pesos iguais. Na data de referência da pesquisa, a atual área da Prefeitura Regional de Sapopemba estava contida no território de Vila Prudente. 
Mapa 9 - Índice de Desenvolvimento Humano Municipal por prefeitura regional do

Município de São Paulo- 2010

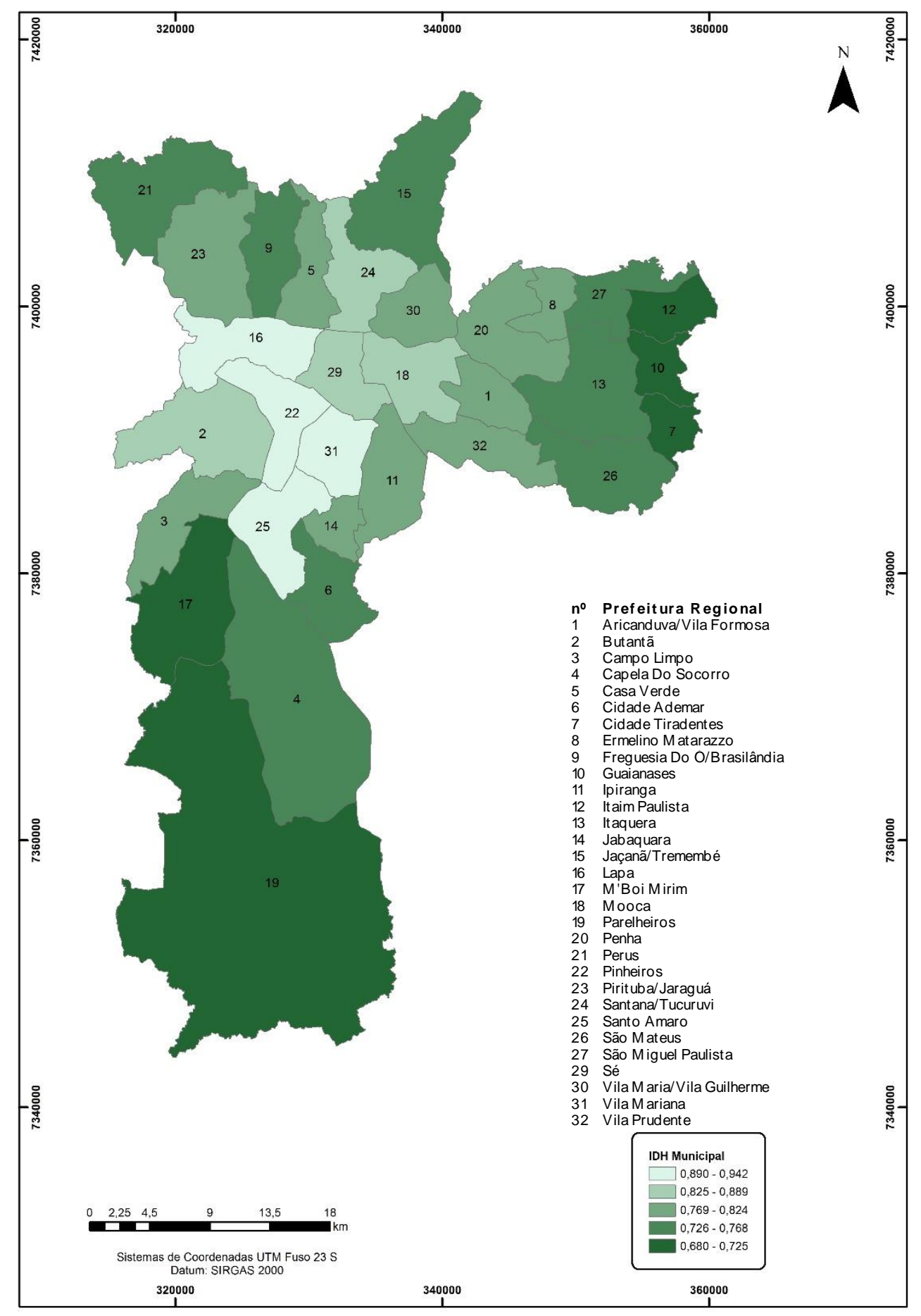

Fonte: IPEA et al., 2014. Elaborado pelo autor. 
Uma breve observação da distribuição da formação básica, da renda per capita e do IDH permite visualizar um padrão de concentração dos melhores indicadores socioeconômicos, e consequentemente das melhores condições de vida e acesso à cidade nas prefeituras regionais situadas no eixo central do município, notadamente as Prefeituras Regionais de Pinheiros, Vila Mariana, Santo Amaro, Lapa e Sé - em todos os indicadores essas regionais encontram-se nas primeiras posições. Por outro lado, Parelheiros, Cidade Tiradentes, Guaianases, M'Boi Mirim, Perus e Itaim Paulista aparecem nas últimas colocações dos indicadores sociais.

Sob uma perspectiva hipotética, pode-se imaginar que nos bairros e distritos com renda média elevada, há melhores estruturas construídas, melhores alternativas de deslocamentos e acesso facilitado a serviços diversos, o que faria com que os CPM dessas pudessem se concentrar em demandas mais precisas e muito específicas. Por um lado, há mais recursos e tempo disponível para a participação, no entanto a concentração de habitantes que não necessitam com urgência da ação do Estado para reproduzir seu cotidiano pode ser um fator de desmobilização.

A formação educacional básica é um fator importante na participação representada nos CPM, na medida em que facilita a compreensão da linguagem das reuniões, dá uma dimensão maior sobre o funcionamento da estrutura do Estado e ainda confere mais peso nas argumentações empreendidas nos debates com outros conselheiros. Há estudos que apontam que dentre os indicadores sociais, a formação é um dos que possui maior influência no potencial de participação política, mesmo que considerando apenas a perspectiva eleitoral (MARIN; GUERRINI, 2017).

Se as condições geográficas profundamente desiguais da capital paulista realmente estabelecerem obstáculos objetivos ao potencial de integração da população em fóruns participativos, então a experiência dos CPM é propensa a ser mais exitosa nas áreas do eixo central da cidade. 


\subsection{A influência das condições geográficas de participação segundo a experiência dos conselheiros dos conselhos participativos municipais}

O levantamento de condições geográficas gerais da cidade possui inúmeras possibilidades de abordagem, tanto da perspectiva referencial quanto em relação às condições de acessibilidade e econômicas da população. Optou-se nos dois tópicos anteriores (2.1 e 2.2) pela descrição de algumas dessas condições que fossem aparadas em dados objetivos ou quantitativos. A se basear pelos resultados obtidos, no geral, observa-se que há maiores barreiras à participação popular em canais ligados às prefeituras regionais da periferia da cidade. Prefeituras regionais como Pinheiros e Vila Mariana, com condições de vida melhores em aspectos como acessibilidade, renda e escolaridade seriam muito mais convidativos à participação nos CPM ou em outros fóruns políticos coletivos ligados ao Estado. Obviamente essa afirmação é uma aproximação muito geral, não se ignora a existência de singularidades em várias comunidades que integram os territórios das prefeituras regionais. Há diversos casos, por exemplo, em que movimentos sociais, como associações de moradores, articulam-se para levar um maior número de participantes às reuniões específicas, audiências públicas, etc. Contudo, do ponto de vista estrutural, as oportunidades para se acessar às sedes de prefeituras regionais e de poder acompanhar ativamente as atividades de planejamento são facilitadas em certos espaços da cidade.

Porém, as experiências nas reuniões dos CPM e os diversos relatos de conselheiros contradizem em parte essas considerações acerca da influência da geografia da cidade no processo participativo. Nem mesmo nas entrevistas realizadas houve respostas explicitamente apontando no sentido das condições geográficas desiguais como obstáculo à participação. Isso pôde ser observado pelo fato de que as perguntas $4,5,10,11^{46}$ - as que dariam mais margem aos comentários sobre os obstáculos geográficos à participação - não terem sido respondidas no sentido de ratificar as hipóteses teóricas discutidas nos tópicos anteriores.

Essa percepção também se estende às questões referenciais: os conselheiros ativos em geral alegaram conhecer as atribuições dos CPM em relação aos outros canais participativos, e

\footnotetext{
${ }^{46}$ Para consultar o questionário, ver Apêndice A. Foram realizadas um total de 12 entrevistas com os questionários, aplicadas a conselheiros eleitos nas prefeituras regionais visitadas durante a pesquisa. Embora os relatos ouvidos nas reuniões sejam de suma importância, as entrevistas com o questionário sistematizou as impressões, fazendo com que um grupo de conselheiros respondessem a todas as dimensões que investigamos na pesquisa.
} 
admitem reconhecer as limitações de ações das prefeituras regionais frente às secretarias setoriais ou a estruturas de gestão estaduais e federais.

A questão da quantidade de população representada por conselho foi citada muito timidamente como problema, porém não houve comentários espontâneos, nesse sentido, os conselheiros que eram favoráveis a um número maior de conselhos no município geralmente o responderam após serem perguntados especificamente sobre o assunto. Da mesma forma, a acessibilidade não foi citada como obstáculo significativo, a não ser quando era associada à crítica pelo não cumprimento da concessão de créditos de passagem de transporte coletivo aos conselheiros ativos.

As desigualdades de formação e renda também não foram explicitamente citadas como obstáculos relevantes à participação. Aliás, houve diversos relatos nas reuniões e nas conversas individuais com os conselheiros em que se ressalta que a vivência em outros grupos participativos, associações ou movimentos sociais pode ser mais importante que a formação escolar/acadêmica. Apesar disso, pode-se observar na dinâmica das reuniões que os conselheiros mais destacados possuem algum grau mínimo de formação escolar.

O maior problema relatado como desmobilizador pelos conselheiros consultados é a falta de resultados objetivos da atuação nos CPM. Diversos conselheiros disseram que muitos acabam desistindo de integrarem o fórum em razão de perceberem a fragilidade do órgão em termos de poder de ação efetivo. Considerando essas afirmações, cabe um questionamento: até que ponto os motivos que levam cidadãos a não participar dos CPM podem ser indicados pelos conselheiros ativos? Não seria mais seguro saber a opinião dos conselheiros desistentes, por exemplo? Com base nesses questionamentos, é importante ter prudência e não desconsiderar completamente as condições geográficas da cidade como facilitadores ou obstáculos à participação com aparo apenas nas opiniões dos conselheiros ativos, pois estes em geral são uma parcela da população com algum grau de mobilização política pregressa. Dada as opiniões mais críticas dos conselheiros sobre os limites de atuação prática dos CPM, resta-nos verificar algumas das dimensões dos resultados do trabalho dessas instâncias. 


\section{POSSIBILIDADES E LIMITES DE PRODUÇÃO DO ESPAÇO URBANO NAS PREFEITURAS REGIONAIS POR MEIO DA PARTICIPAÇÃO POPULAR}

\subsection{Limites da autonomia das prefeituras regionais e os CPM: questões orçamentárias}

Os conselhos participativos municipais são instâncias que atuam institucionalmente no âmbito das prefeituras regionais. Nesse sentido, mesmo sabendo de antemão seu caráter estritamente consultivo, faz-se necessário compreender o nível de autonomia e poder de ação concreto da instituição que o abriga - as prefeituras regionais - para ter uma indicação da possibilidade das decisões dos CPM redundarem em mudanças significativas na geografia da cidade - considerando a hipótese dos prefeitos regionais acaterem às formulações dos CPM.

Um dos elementos fundamentais para se verificar o nível de autonomia de um ente político do Estado é a quantidade de recursos econômicos que ele detém e as possibilidades de realização de investimentos. Afinal, é por meio de recursos financeiros que se contratam pessoas, prestadores de serviços, realizam-se obras e outros tipos de investimentos. Além da posse de quantidade de recursos financeiros, é importante também verificar a forma de arrecadação desses recursos e o grau de liberdade que a unidade político-administrativa ou os gestores possuem de realizar investimentos novos.

No Brasil, a arrecadação é realizada pela União, estados e municípios, de modo que não é permitida uma tributação específica para unidades administrativas inframunicipais, tais como as prefeituras regionais. Em alguns casos há leis que obrigam os entes estatais e destinarem compulsoriamente parte de suas receitas a fins específicos, um exemplo é a obrigatoriedade dos municípios aplicarem pelo menos $15 \%$ de seus impostos em ações e serviços de saúde (Lei Complementar $n^{\circ} 141,2012$ ). Este não é o caso das prefeituras regionais paulistanas, elas na prática absorveram no momento de sua criação parte do orçamento destinado às ações de zeladoria, já que a elas foi destinada essa atribuição ${ }^{47}$. Apesar disso, não há uma norma que contenha critérios específicos sobre os repasses de verbas para as prefeituras regionais, fazendo

\footnotetext{
${ }^{47}$ As ações de zeladoria transferidas das secretarias municipais às subprefeituras foram as seguintes: "I - limpeza, desassoreamento e contenção de margens de cursos d'água, de reservatórios de contenção de cheias, de galerias e de bocas-de-lobo; II - pavimentação de vias de tráfego local; III - construção, reforma e manutenção de galerias tubulares, poços de visita e de drenagem superficial, como guias, sarjetas, sarjetões; IV - recapeamento, reconstrução, conservação e manutenção do pavimento de ruas e avenidas e estradas vicinais; V - conservação de passeios e áreas verdes; VI - construção e conservação de escadarias, vielas, muros de arrimo e passarelas de pedestres" (SÃO PAULO [Município], Decreto n $\left.{ }^{\circ} 42.239,2002\right)$.
} 
com que as destinações orçamentárias sejam flutuantes a depender do governo ou da circunstância, e também das relações executivo e legislativo para a liberação de emendas parlamentares destinadas a localidades específicas do município. Os Gráficos 1 e 2 a seguir sintetizam as despesas gerais do município com a descentralização administrativa representada pelas regionais:

\section{Gráfico 1 - Despesas liquidadas totais (milhões de R\$) das prefeituras regionais do} Município de São Paulo entre 2003 e 2016

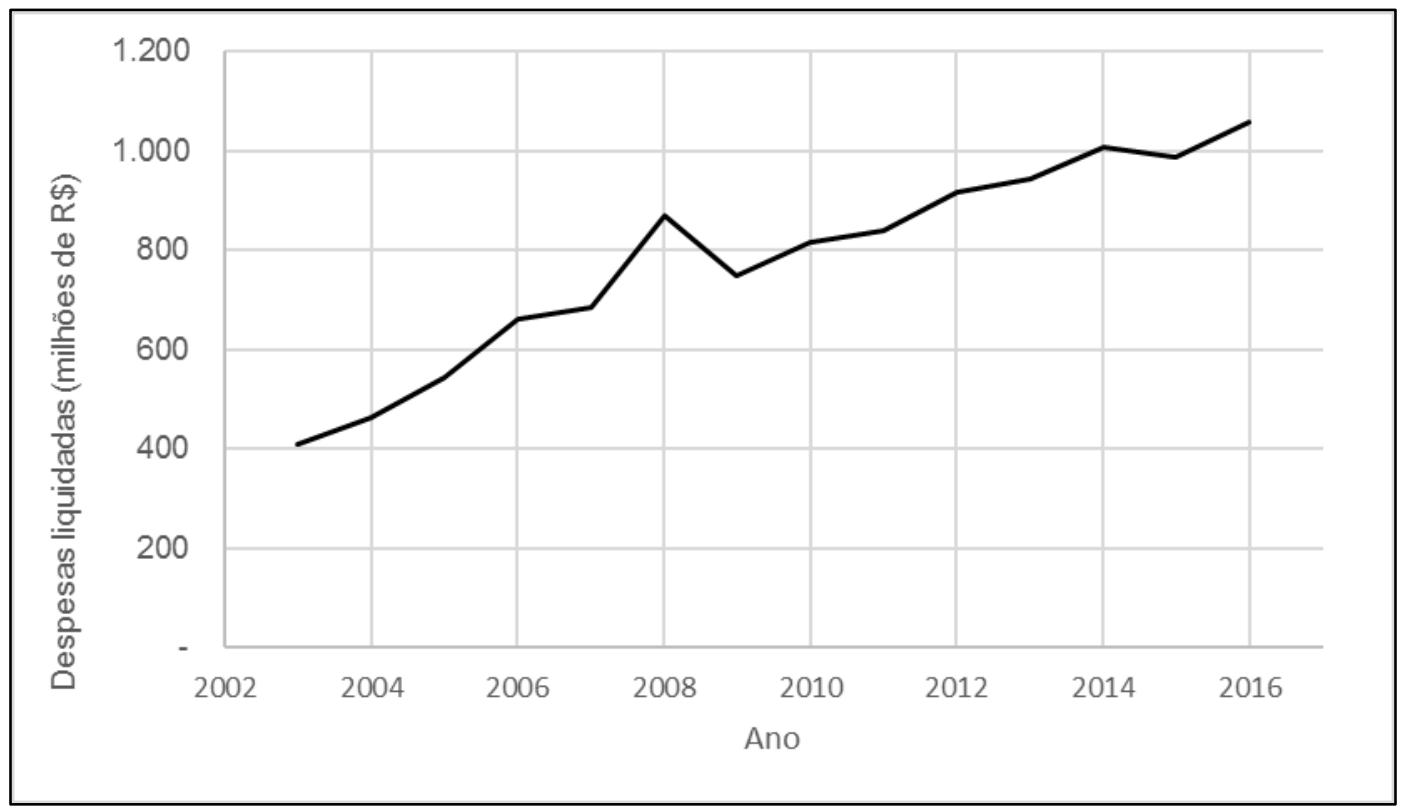

Fonte: PMSP-SF (2017). Elaborado pelo autor.

Nota: O total das despesas com as prefeituras regionais levou em consideração os aportes das regionais em si, mas também os relativos à Secretaria Municipal de Coordenação das Subprefeituras, inclusive às rubricas dessa unidade provenientes do Fundo de Desenvolvimento Urbano (FUNDURB).

Gráfico 2 - Participação (\%) das prefeituras regionais nas despesas liquidadas totais no Município de São Paulo entre 2003 e 2016 


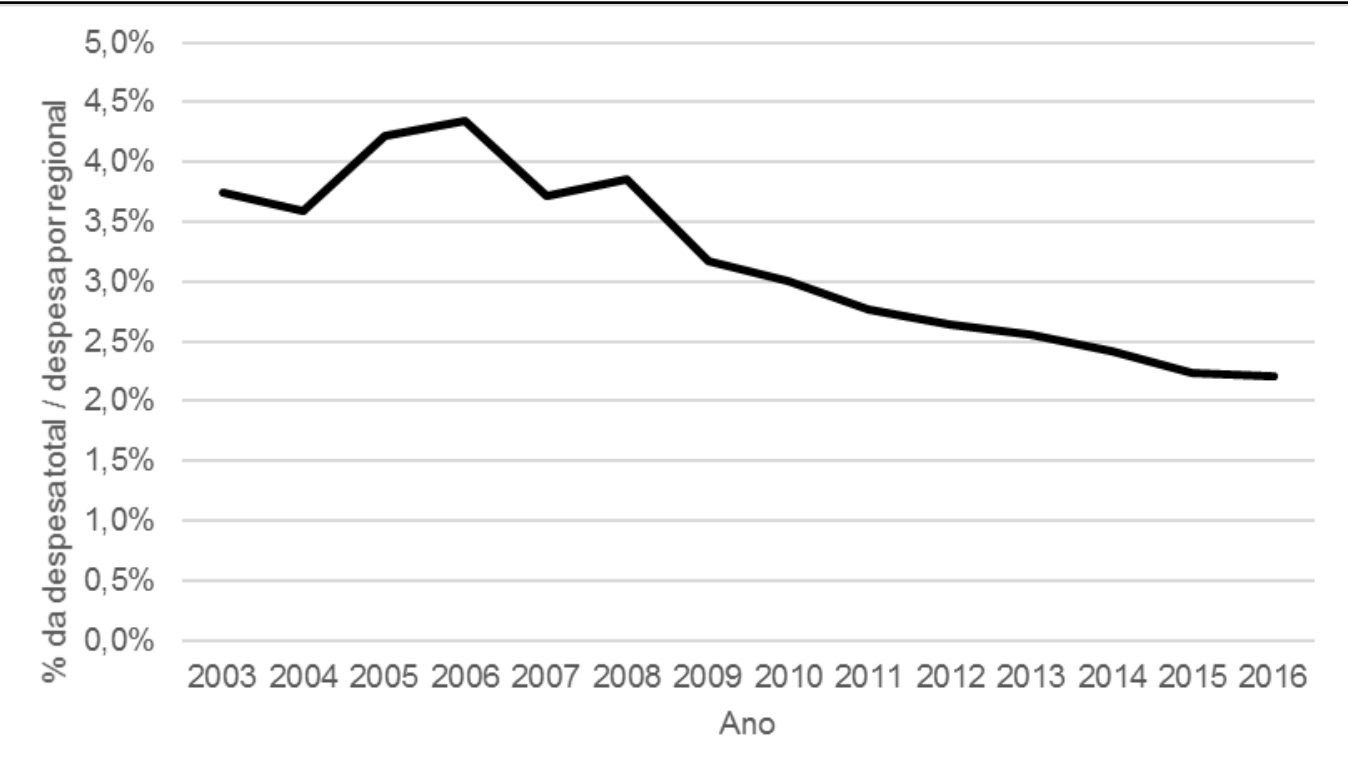

Fonte: PMSP-SF (2017). Elaborado pelo autor.

Nota: O total das despesas com as prefeituras regionais levou em consideração os aportes das regionais em si, mas também da Secretaria Municipal de Coordenação das Subprefeituras, inclusive às rubricas dessa unidade provenientes do Fundo de Desenvolvimento Urbano (FUNDURB).

O primeiro Gráfico 1 mostra que a tendência de 2003 a 2016 foi um leve aumento das despesas totais do município com as prefeituras regionais, ultrapassando o patamar de $\mathrm{R} \$ 1$ trilhão em 2014. Houve apenas um registro de redução de gastos com regionais, em 2015, e um caso de aumento muito acima do padrão, em 2008, mas no restante do período prevaleceu uma tendência média de acréscimo paulatino de gastos. Contudo, o segundo Gráfico 2 revela que o aumento das despesas com prefeituras regionais ocorreu apenas de modo absoluto. Ao se comparar a evolução das despesas das prefeituras regionais com as despesas totais do município no período, percebe-se uma tendência geral de redução das despesas. De 2003 até 2006, nos primeiros anos das então subprefeituras, houve aumento relativo de despesas - em consonância com o discurso de empoderamento local -, chegando a 4,4\% do total das despesas totais do município em 2006. Nos anos seguintes, observa-se uma tendência geral de redução relativa dos gastos, chegando a 2,2\% em 2016. Dessa forma, percebe-se que o aumento das receitas municipais não é acompanhado de incremento proporcional de receitas às prefeituras regionais - esse quadro seria ainda pior se fosse considerada a inflação no período. Apesar dos diferentes governos municipais discursarem em favor da descentralização administrativa, o que se viu foi num intervalo de quase 15 anos os gastos relativos com as prefeituras regionais serem reduzidos pela metade. 
Outro fator a ser considerado para a autonomia financeira das prefeituras regionais é a potencialidade de investimentos livres que elas possuem para realizar projetos novos, ou seja, a verificação da parcela orçamentária que não é comprometida à priori. A Tabela 6 a seguir mostra quais os projetos e atividades com os quais as prefeituras regionais mais gastam.

\begin{tabular}{|c|c|c|}
\hline \multicolumn{3}{|l|}{ projeto ou atividade -2016} \\
\hline Descrição do projeto ou atividade & Despesa Liquidada $(\mathrm{R} \$)$ & Percentual \\
\hline Total & 1.057.918.278 & $100,0 \%$ \\
\hline Administração da Unidade & 532.225 .504 & $50,3 \%$ \\
\hline Manutenção de vias e áreas públicas & 185.103 .662 & $17,5 \%$ \\
\hline Manutenção de sistemas de drenagem & 126.610 .887 & $12,0 \%$ \\
\hline Conservação de áreas verdes e vegetação arbórea & 107.226 .416 & $10,1 \%$ \\
\hline Intervenção, Urbanização e Melhoria de Bairros - Plano de Obras das Subprefeituras & 50.081 .621 & $4,7 \%$ \\
\hline Reforma e Acessibilidade em Passeios Públicos & 18.722 .790 & $1,8 \%$ \\
\hline Requalificação de Bairros e Centralidades & 14.982.072 & $1,4 \%$ \\
\hline Outros & 22.965 .326 & $2,2 \%$ \\
\hline
\end{tabular}

Fonte: PMSP-SF (2017). Elaborado pelo autor.

Nota: O total das despesas com as prefeituras regionais levou em consideração os aportes das regionais em si, mas também da Secretaria Municipal de Coordenação das Subprefeituras, inclusive às rubricas dessa unidade provenientes do Fundo de Desenvolvimento Urbano (FUNDURB).

A Tabela 6 mostra que 50,3\% dos gastos com prefeituras regionais em 2016 ocorreu para a administração das unidades, em questões como pagamento de servidores, despesas com materiais de consumo, manutenção dos prédios próprios e contratação de serviços administrativos. Em seguida, as despesas mais significativas são aquelas com atividades típicas de zeladoria urbana: manutenção de vias e áreas públicas, manutenção de sistemas de drenagem e conservação de áreas verdes e vegetação arbórea. A rubrica reforma e acessibilidade de passeios públicos pode também somar-se às outras categorias de zeladoria, de modo que as quatro classes somadas perfizeram um total de 41,4\% das despesas liquidadas em 2016 nas prefeituras regionais. Desse modo, resta menos de $10 \%$ para diversas outras atividades e despesas das prefeituras regionais, entre as quais destacam-se a requalificação de bairros e centralidades, com 1,8\% dos investimentos, e os gastos com intervenção, urbanização e melhoria de bairros (plano de obras das subprefeituras), com 4,7\% do total das despesas. Essas duas últimas categorias permitem uma aproximação da quantidade de despesas efetivamente empenhada em projetos e atividades originais, que produzam espaços novos na cidade ou que modifiquem profundamente a paisagem, nesse sentido observa-se que há pouca margem para as prefeituras regionais intervirem livremente nas suas áreas de jurisdição com os recursos que 
detém. A maior parte do orçamento, e consequentemente das despesas, acabam por ficar engessadas.

Outra questão orçamentária que não se pode desprezar para averiguar a autonomia efetiva das prefeituras regionais é a disparidade entre as receitas que recebem cada uma das unidades descentralizadas, tal como exibe a Tabela7.

Tabela 7 - Orçamento municipal $(\mathbf{R} \$)$ por prefeitura regional -2017

\begin{tabular}{|c|c|c|}
\hline Prefeitura Regional & Despesa $(\mathrm{R} \$)$ & Percentual \\
\hline Total & 1.873 .015 .299 & $100,0 \%$ \\
\hline Secretaria Municipal Das Prefeituras Regionais & 532.092 .899 & $28,4 \%$ \\
\hline Sé & 76.191 .260 & $4,1 \%$ \\
\hline Campo Limpo & 60.068 .004 & $3,2 \%$ \\
\hline São Mateus & 58.644 .672 & $3,1 \%$ \\
\hline Ipiranga & 53.861 .216 & $2,9 \%$ \\
\hline Butantã & 52.309 .444 & $2,8 \%$ \\
\hline Socorro & 52.088 .327 & $2,8 \%$ \\
\hline Itaquera & 51.940 .384 & $2,8 \%$ \\
\hline Penha & 48.459 .034 & $2,6 \%$ \\
\hline Mooca & 46.677 .965 & $2,5 \%$ \\
\hline M’Boi Mirim & 46.500 .857 & $2,5 \%$ \\
\hline São Miguel Paulista & 46.039 .298 & $2,5 \%$ \\
\hline Lapa & 42.720 .074 & $2,3 \%$ \\
\hline Pinheiros & 41.779 .896 & $2,2 \%$ \\
\hline Santo Amaro & 41.666 .510 & $2,2 \%$ \\
\hline Cidade Ademar & 41.221 .795 & $2,2 \%$ \\
\hline Guaianases & 40.589 .873 & $2,2 \%$ \\
\hline Freguesia do Ó/Brasilândia & 40.211 .681 & $2,1 \%$ \\
\hline Itaim Paulista & 39.962 .888 & $2,1 \%$ \\
\hline Vila Mariana & 38.736 .779 & $2,1 \%$ \\
\hline Aricanduva/Vila Formosa & 38.088 .221 & $2,0 \%$ \\
\hline Pirituba/Jaraguá & 38.083 .614 & $2,0 \%$ \\
\hline Santana/Tucuruvi & 36.376 .353 & $1,9 \%$ \\
\hline Ermelino Matarazzo & 32.618 .121 & $1,7 \%$ \\
\hline Vila Maria/Vila Guilherme & 32.365 .128 & $1,7 \%$ \\
\hline Vila Prudente & 32.220 .297 & $1,7 \%$ \\
\hline Jaçanã/Tremembé & 32.126 .717 & $1,7 \%$ \\
\hline Jabaquara & 32.031 .936 & $1,7 \%$ \\
\hline Parelheiros & 31.663 .662 & $1,7 \%$ \\
\hline Cidade Tiradentes & 31.195 .509 & $1,7 \%$ \\
\hline Perus & 29.539 .197 & $1,6 \%$ \\
\hline Casa Verde/Cachoeirinha & 28.954 .310 & $1,5 \%$ \\
\hline Sapopemba & 25.989 .378 & $1,4 \%$ \\
\hline
\end{tabular}

Fonte: PMSP-SF (2017). Elaborado pelo autor.

A diferença entre o menor (Sapopemba) e o maior (Sé) orçamento das prefeituras regionais chega a mais de $\mathrm{R} \$ 50$ milhões, um valor bastante expressivo e que corresponde a 
quase o triplo de diferença. Como já mencionado, não há uma normatização clara a respeito dos critérios usados para repasses à prefeituras regionais, no entanto há em parte uma correlação com os equipamentos públicos existentes em cada regional e que necessitam de manutenção, isso explica parcialmente o fato da Prefeitura Regional da Sé ter o maior orçamento. Entre as prefeituras regionais menos favorecidas do ponto de vista socioeconômico, há algumas com orçamentos entre os maiores, como São Mateus, e entre os piores, como Perus. De qualquer forma, seria razoável que houvesse um critério mais claro e transparente de distribuição de recursos entre as unidades, levando em consideração questões como tamanho da população, indicadores sociais e outras demandas específicas.

Se nem mesmo as prefeituras regionais enquanto níveis administrativos do executivo municipal possuem um grau acentuado de autonomia orçamentária, a situação é ainda mais dramática se considerar especificamente as verbas destinadas aos conselhos participativos. Pelas possibilidades de consultas disponíveis no quadro completo de despesas, em 2016 deduzse que apenas $\mathrm{R} \$ 230.736,10$ foram gastos com os CPM em todas as prefeituras regionais. Isso perfaz $0,017 \%$ do total das despesas com prefeituras regionais, e uma média de $\mathrm{R} \$ 7.210,50$ por CPM - valor que possivelmente está superestimado por conter outros valores embutidos. Em verdade, os valores destinados aos CPM acabam sendo utilizados apenas para cobrir pequenas necessidades do fórum, como um computador próprio para realizar as atas, materiais de papelaria, etc.

Há outro dado importante a ser considerado quando se considera a questão orçamentária relacionada com a participação: a extinção do Conselho de Planejamento e Orçamento Participativo (CPOP) em $2017^{48}$. O CPOP tinha como parte da composição dos seus membros conselheiros oriundos dos CPM - dois conselheiros por prefeitura regional. Com a extinção dessa instância participativa, perdeu-se mais uma potencialidade de obtenção de recursos financeiros em favorecimento às prefeituras regionais e aos territórios locais.

A partir dos dados analisados sobre as despesas executadas e os orçamentos das prefeituras regionais paulistanas, conclui-se que as despesas com os governos descentralizados

\footnotetext{
$48 \mathrm{O}$ orçamento participativo tem uma dinâmica bastante irregular no Município de São Paulo. Houve uma experiência no governo Marta Suplicy (2001-2004) que foi interrompida no governo seguinte, do tucano José Serra (2005-2006) (MARIN; GUERRINI, 2017). Apenas em 2014, na gestão do petista Fernando Haddad o orçamento participativo foi retomado na forma do CPOP (SÃO PAULO [Município], Decreto no 54.837, 2014). Em 2017, sob a gestão de João Doria, do PSDB, o CPOP foi revogado, passando a participação direta na formulação do orçamento a ser realizada apenas por meio de audiências públicas (SÃO PAULO [Município], Decreto $\mathrm{n}^{\circ}$ 57.802, 2017).
} 
é pequena em face ao tamanho dos gastos municipais, as despesas vêm gradualmente se reduzindo do ponto de vista relativo no decorrer dos últimos quinze anos, há falta de critérios para distribuição dos recursos existentes, bem como desigualdade nessa distribuição, e por fim os CPM possuem verba quase simbólica e não mais possuem voz na definição do orçamento geral da cidade, haja vista a extinção do CPOP. Tratam-se de condições que obstaculizam de maneira muito significativa a possibilidade de atuação das prefeituras regionais, e consequentemente dos CPM. Esse quadro de distribuição de recursos para as prefeituras regionais leva a ideia de que, na perspectiva orçamentária, as secretarias setoriais são priorizadas em relação às estruturas descentralizadas. Por isso, para delinear o quadro político administrativo no qual os CPM se inserem, há necessidade de averiguar melhor as relações entre gestão centralizada e descentralizada no município e os eventuais conflitos entre agentes públicos que ocupam cargos nesses órgãos. 


\subsection{Limites da autonomia das prefeituras regionais e os CPM: atribuições e intervenções político-partidárias}

As prefeituras regionais têm certa autonomia para administrarem o território sob sua jurisdição, inclusive elaboram um plano regional próprio. Apesar disso a autonomia é limitada por diversos instrumentos da gestão pública municipal, como o Plano Diretor Estratégico, os planos setoriais das secretarias e o próprio poder executivo central. Em geral, a principal atividade das prefeituras regionais acaba sendo a zeladoria urbana, conforme verificado pela execução das despesas da maioria das prefeituras regionais. Além disso, trata-se de uma instância com indicações políticas para cargos gerenciais, característica com grande potencial para causar conflitos periódicos.

A divisão do município em prefeituras regionais, embora consolidada e reconhecida, teve algumas oscilações de importância e atribuições práticas de acordo com as diferentes gestões da prefeitura municipal dos últimos anos (MARIN; GUERRINI, 2017). Seu estatuto autônomo teria sido sensivelmente reduzido a partir da gestão do prefeito José Serra (2005 2006) e de Gilberto Kassab $(2006 \text { - 2013 })^{49}$, constatação exemplificada pelo embargo à regulamentação dos conselhos de representantes, pela extinção do orçamento participativo e pela nomeação quase exclusiva de subprefeitos coronéis da Polícia Militar. Aldaíza Sposati chegou a afirmar em 2012 que "é decepcionante constatar que os antigos administradores

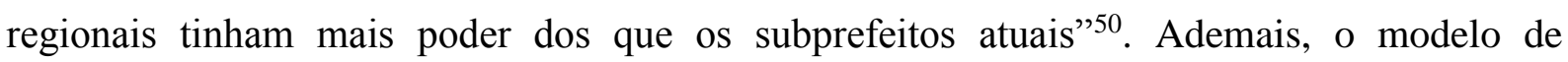
descentralização proposto deixou uma série de lacunas ainda não totalmente equalizadas:

\footnotetext{
49 José Serra pertence ao Partido da Social Democracia Brasileira (PSDB) e Gilberto Kassab integrava o Partido da Frente Liberal (PFL), o qual posteriormente foi renomeado para Democratas (DEM). Desde de 2011, ainda em sua gestão, transferiu-se para o recém-criado Partido Social Democrático (PSD). Kassab era vice-prefeito de Serra e assumiu a prefeitura quando este deixou o cargo para se candidatar a governador. Em 2008, Kassab foi eleito e reconduzido à prefeitura.

${ }^{50}$ Os Conselhos de Representantes foram regulamentados pela Lei ${ }^{\circ} 13.881$ (SÃO PAULO [Município], Lei ${ }^{\circ}$ 13.881, 2004). No entanto, após ação do Ministério Público de São Paulo, a lei foi julgada inconstitucional pelo Tribunal de Justiça do Estado de São Paulo (TJ-SP), assim como os artigos 54 e 55 da Lei Orgânica, referentes ao Conselho de Representantes, por meio da Ação Direta de Inconstitucionalidade $n^{\circ}$ 118.997.0/4-00 (PMSP-SMSP, 2005). Embora o Ministério Público paulista não tenha agido por denúncia realizada pelo governo da época, a omissão da prefeitura somada a algumas críticas ao Conselho por parte de membros do governo deixou claro que havia apoio a não criação da instância participativa. Após recursos da decisão do TJ-SP, ainda não houve julgamento do Supremo Tribunal Federal (STF), o qual decidirá definitivamente se esse fórum de representação é ou não constitucional.

Sobre a recentralização da gestão municipal, o assunto foi amplamente debatido no seminário Distritalização de São Paulo, que ocorreu em maio de 2012, para fazer o balanço dos novos distritos, 20 anos após sua implementação. O padre José Crowe, que atua no Distrito de Jardim Ângela, foi ainda mais crítico que Sposati, pois afirmou que "nesta última administração [governos José Serra e Gilberto Kassab], de 2005 para cá, as
} 
Até onde vai a função de orientação e coordenação técnica das secretarias para não se confrontar com a autoridade do subprefeito? Como combinar operacionalmente um modelo de gestão territorial que tem como autoridade um subprefeito e a adoção de políticas específicas em saúde, educação, etc., orientadas pelas secretarias centrais? Qual a instância ou em que nível se produz a cominação do atendimento das demandas estruturais definidas de forma centralizada e aquelas nas quais as subprefeituras possuem autonomia decisória? Essas ainda são questões a que o desenvolvimento do modelo deverá responder, juntamente com uma revisão da estrutura organizacional e de atribuições dos órgãos da administração direta e indireta (FINATEC, 2004, p.124).

Segundo Grin (2015), houve diferenças significativas entre o plano original de implementação das subprefeituras, ainda no período eleitoral em 2000, e o modo como ele foi aplicado na lei em 2002. Divergências internas no Partido dos Trabalhadores teria feito com que ocupantes de cargos nas secretarias temessem a redução de seus poderes em detrimento das subprefeituras. Por esse motivo a proposta original de integração dos serviços nas subprefeituras foi muito prejudicada, pois as secretarias delegaram funções às unidades regionais em graus diferentes. Segundo Grin (2015):

Como não havia concordância de todas as Secretarias com a descentralização, era pequena a possibilidade de se criarem tais fóruns integrados na esfera central. Um efeito não previsto dessa oposição foi transformar as Secretarias, e não as Subprefeituras, em protagonistas da descentralização, pois passaram a condicionar a forma, o ritmo e o seu conteúdo. É nesse sentido que a implantação das Subprefeituras foi errática, limitada em alcance administrativo e desigual na capacidade de gerir políticas públicas nas regiões, o que impactou sua capacidade de inovar na gestão local

Na época de discussão da implantação das subprefeituras na gestão Marta Suplicy, teria havido temores de que o projeto não fosse aprovado por falta de apoio parlamentar. Havia uma avaliação de que o governo Erundina tinha falhado ao aprovar o projeto anteriormente por estar em relativo isolamento político. Dessa vez o Poder Executivo não quis correr esse risco e, por esta razão, o cargo de subprefeitos e outros de segundo escalão dentro das subprefeituras foi distribuído a determinados grupos políticos para a composição da base parlamentar para garantir aprovação da lei. Essa prática de distribuição de cargos para governabilidade era exatamente a crítica que era feita anteriormente às administrações regionais. Segundo Grin (2015):

Em vez de combater o fisiologismo, como anunciado em seu programa de governo, o PT majoritariamente aliou-se a essa prática política. No núcleo político do Executivo e na bancada petista predominaram os vereadores "pragmáticos", favoráveis à

subprefeituras

deixaram

de

existir". As respectivas informações foram publicadas em matéria da Escola de Governo (GOES, 2012), e está disponível online. Disponível em: <http://escoladegoverno.org.br/index.php/noticias/1365-papel-de-subprefeituras-ecriticado-em-debate-sobre-distritalizacao-da-cidade>. Acesso em: 25 jan. 2015. 
negociação com os vereadores protagonistas do "toma-lá-dá-cá" tradicional na política municipal.

Desse modo, percebe-se que logo no início da implantação das subprefeituras, boa parte das possíveis prerrogativas de descentralização política-administrativa não foram colocadas em prática. Por este motivo, a descentralização ocorreu de forma errática, de maneira que o nível de integração dos serviços em cada subprefeitura dependia, entre outros fatores, do nível de influência do subprefeito e das decisões das secretarias setoriais Grin (2015).

Outro aspecto da implantação das subprefeituras que foi sensivelmente modificado foi a inserção da população local na administração. Essa era uma das principais bandeiras da criação das subprefeituras, entretanto, os referidos fatores políticos acabaram inibindo o aprofundamento dos mecanismos participativos. Para Grin (2015):

\begin{abstract}
O debate sobre a participação popular esteve na agenda do governo desde seu início, mas a estratégia de estreitar os vínculos do PT com os movimentos sociais, além de estimular a participação local, foi secundarizada pelo governo municipal. A importância que os vereadores ganharam como fiadores da governabilidade reduziu o "participacionismo" a um papel secundário na política do Executivo.
\end{abstract}

Os governos subsequentes aprofundaram a falta de autonomia das subprefeituras. Sobre isso destaca-se a posição dos integrantes do governo Serra e Kassab frente à anulação dos conselhos de representantes. Embora o processo tenha sido iniciado pelo Ministério Público paulista e julgado no TJ-SP, o referido governo era contrário à criação do órgão tal como previsto na Lei Orgânica Municipal. Sobre o assunto, Walter Feldman - à frente da pasta das subprefeituras em 2008 - discordava da eleição direta pela população de representantes nas subprefeituras já que "a votação direta em candidatos deve ser feita para cargos do Executivo e Legislativo porque são esses os representantes e responsáveis pela administração" ${ }^{\text {. }}$. No governo Kassab, as subprefeituras foram tacitamente ainda mais centralizadas por meio da escolha de coronéis da Polícia Militar para assumir os cargos de subprefeitos. O governo Haddad, apesar de ter tomado a iniciativa de criar os conselhos participativos municipais, foi criticado em determinados momentos pela redução de repasses de verbas às subprefeituras ${ }^{52}$, além da manutenção de práticas de distribuição de cargos para promover a coalização governista na Câmara Municipal.

\footnotetext{
51 Trecho de entrevista concedida ao Jornal da Gente (2008). Disponível em: <http://jornaldagente.tudoeste.com.br/2008/09/28/feldman-contesta-conselho-de-representantes//>. Acesso em: 25 jan. 2016.

52 Segundo matéria do jornal O Estado de São Paulo (ESTADÃO, 2014). Disponível em: < http://saopaulo.estadao.com.br/noticias/geral,verbas-destinadas-as-subprefeituras-caem-em-2015,1569939>. Acesso em: 25 jan. 2016.
} 
A partir dessas reflexões, percebe-se que a centralização dos recursos financeiros do munícipio em benefício das secretarias e órgãos centrais e em detrimento às prefeituras regionais, pode ser encarada como uma continuidade de um fenômeno de disputa de poder intraestatal na máquina municipal desde a criação das subprefeituras, ainda em 2002. Nesse sentido, observam-se conflitos intragoverno para reivindicar a autoria de melhorias nos bairros e, dessa forma, capitalizar politicamente as ações de gestão e produção da cidade. Não obstante, muitas vezes as regionais são usadas como base de apoio para candidaturas ao legislativo municipal. Esse expediente ocorre tanto pela influência e trânsito do prefeito regional - que pode tornar os candidatos apadrinhados mais conhecidos nas regiões , quanto pelo processo de distribuição de cargos comissionados na estrutura administrativa da prefeitura regional - em troca de apoio político. Essas questões mostram que o Estado, de maneira ampla, não pode ser tomado como uma unidade monolítica:

Um partido político governando um município pode receber a oposição acirrada do
governador de Estado de um outro partido, por exemplo. Em outras palavras, o Estado
não existe como um sistema operacional "puro', plenamente constituído, internamente
coerente e operacionalmente "fechado", mas deve ser visto como contraditório, sob
certos aspectos híbrido e relativamente "aberto" (LAHORGUE, 2004, p. 27).

Os CPM atuam convivendo com essa lógica do jogo político no executivo municipal e ao mesmo tempo participando ativamente das disputas intraestatais. A reprodução da lógica da disputa intraestatal é bem observada nos processos eleitorais para a escolha dos conselheiros, nos quais são comuns a formação de grupos de alianças para as eleições com base em organizações político-partidários, frequentemente em cooperação com vereadores ou futuros candidatos a vereadores. Um dos conselheiros entrevistados relatou que muitos membros do conselho se candidatam por orientação dos partidos, ou para tornarem-se mais conhecidos em uma região, "preparando o terreno" para eleições em anos seguintes para cargos de vereador ou deputado estadual. Na saída de uma das reuniões do CPM, em Itaquera, foi possível observar numa conversa reservada um conselheiro convidando outro membro do conselho para integrar sua equipe de campanha nas eleições de 2018 para Assembleia Legislativa de São Paulo. Esse tipo de situação deixa evidente a noção de que os CPM estão plenamente inseridos nas questões políticas - inclusive partidárias gerais da cidade.

Figura 7 - Reunião ordinária do CPM de Itaquera em 28/09/2017 


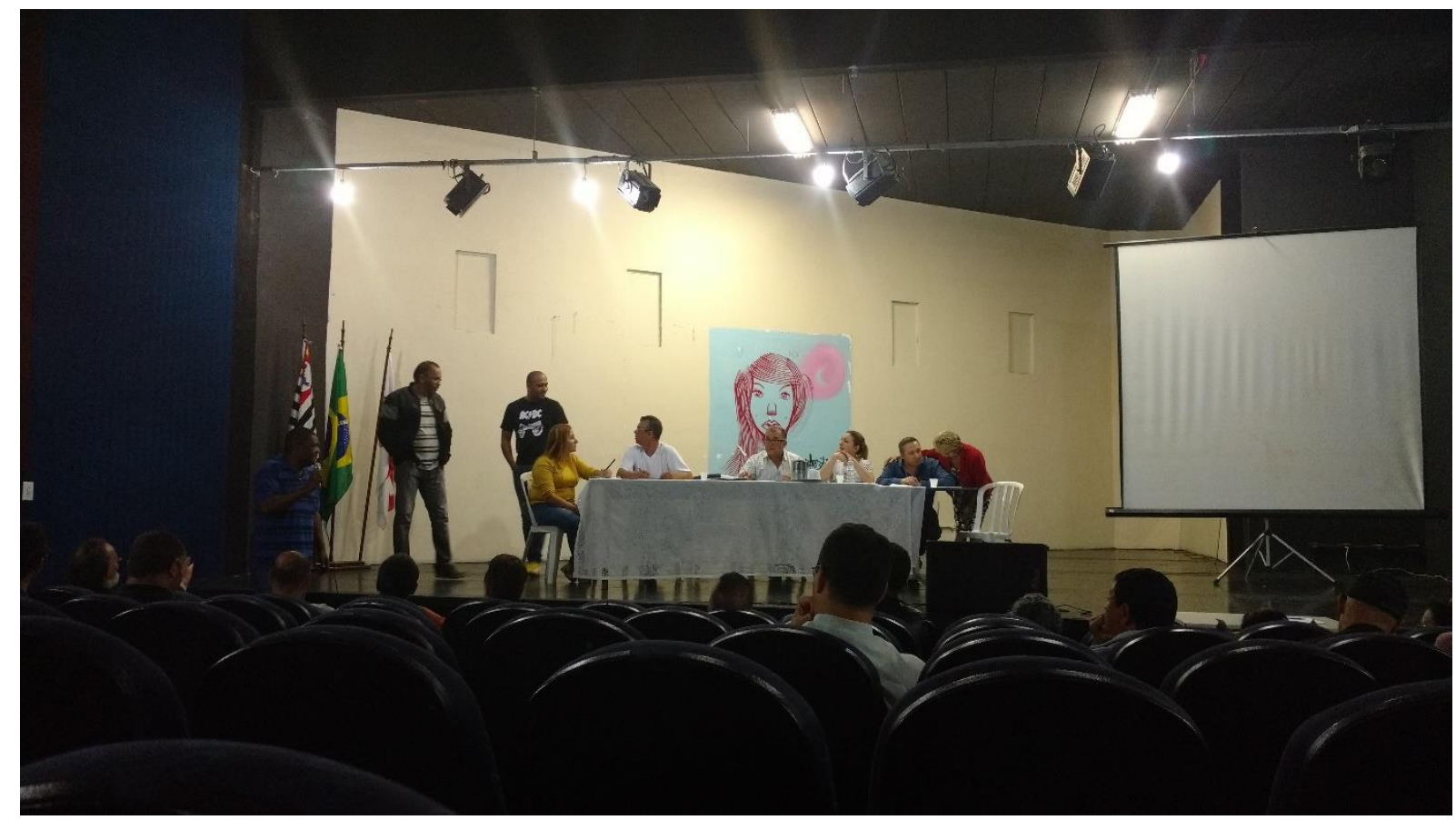

Fonte: Acervo do autor.

Nota: Nessa reunião, estava presente um chefe de gabinete de um vereador. Houve momentos de discussões acaloradas, em que se ouviram falas entre os conselheiros como a seguinte "o conselho é do povo, não dos políticos!”.

Essas reflexões mostram que por mais que os prefeitos e prefeitas regionais exerçam seus mandatos, não necessariamente eles gozam de plena condição de governarem as regiões conforme suas convicções. Em geral há a necessidade de prestar contas não só ao prefeito e ao CPM como previsto formalmente, mas também aos padrinhos políticos, ao partido e a outros membros da burocracia estatal. O conjunto desses fatores tem a capacidade de reduzir a autonomia concreta da ação de uma prefeitura regional, bem como as mesmas condições podem estimular determinados CPM a terem atitudes mais combativas que outros, a depender da composição dos conselheiros e da relação deles com os gabinetes das prefeituras regionas. 


\subsection{Resultados e desafios da participação popular nos conselhos participativos municipais}

Após a análise das diversas dimensões que impactam o processo participativo, tanto aquelas ligadas às condições geográficas desiguais da cidade, quanto as dimensões relativas a autonomia das prefeituras regionais, neste tópico serão elencados os principais desafios e potencialidades na atuação dos CPM, de acordo com os levantamentos feitos nas reuniões ordinárias e nos diálogos com os conselheiros.

\subsubsection{A relação entre as prefeituras regionais e os conselhos participativos municipais}

Um dos maiores desafios verificados no processo de inserção nas reuniões dos CPM foi a relação entre as prefeituras regionais e os conselheiros. Formalmente, essas duas instâncias deveriam cooperar para gerir o território sob sua jurisdição, seja na execução de obras simples, como no desenvolvimento de instrumentos mais sofisticados de planejamento e intervenção urbana, como os Planos Regionais Estratégicos e nos Planos de Ações das Subprefeituras.

Apesar das diretrizes legais, o que se observa na prática é uma grande distância entre os gabinetes das prefeituras regionais e os membros dos conselhos participativos, distância essa sempre de responsabilidade dos gabinetes e dos prefeitos das regionais. Todos os conselhos visitados durante a pesquisa possuem um interlocutor - integrante do governo regional - no respectivo CPM, para servir como canal de diálogo, levar as reivindicações dos conselheiros ao prefeito regional, prestar contas, ajudar na organização das reuniões, etc. Contudo, houve numerosas reclamações de conselheiros relatando que muitas vezes nem mesmo o interlocutor comparecia às reuniões. Mesmo quando o interlocutor é ativo, não significa que a prefeitura regional dê satisfações do andamento da gestão das regionais ao CPM - houve diversas reclamações sobre atitudes de prefeitos regionais que ignoram os pedidos dos conselhos. A presença dos prefeitos e prefeitas regionais em reuniões dos CPM são raríssimas, em geral para cumprir algum protocolo, como acompanhar uma autoridade ou para tratar algum assunto de grande urgência.

Nos casos mais raros em que há uma relação de cooperação e proximidade entre prefeituras regionais e CPM, coloca-se um outro problema: a alegação da incapacidade dos gestores atenderem às solicitações do conselho, seja por limitações de atribuição administrativa, 
seja por restrições orçamentárias. Há, na visão de alguns conselheiros, falta de prioridade política para se colocar em prática as solicitações dos conselhos.

\subsubsection{Os grupos políticos nos conselhos participativos}

Um dos assuntos mais levantados nos relatos dos conselheiros foi a presença de grupos políticos organizados nos conselhos participativos, tanto os de cunho partidário, quanto aqueles ligados a associações civis e movimentos sociais. Há consenso de que uma parte bastante expressiva dos conselheiros eleitos sejam oriundos de grupos desse tipo, mas possivelmente não chega a ser a maioria.

No geral, a avaliação dos conselheiros sobre o assunto dos grupos políticos é dúbia: por um lado, valorizam o poder de mobilização desses grupos, e pensam que podem somar forças na atuação do CPM, por outro repudiam a falta de compromisso que alguns desses grupos possuem com os territórios em si, pois têm prioridades maiores com a preparação de campanhas para cargos legislativos. Houve relatos de grupos eleitos por influência de vereadores, partidos ou movimentos sociais que se ausentam abruptamente dos CPM após pouco tempo de atuação

\subsubsection{A questão das ausências de conselheiros e munícipes}

Talvez o maior dos desafios relativos ao funcionamento dos CPM seja a baixa proporção de conselheiros presentes nas reuniões em relação ao total de conselheiros eleitos. Há muitas desistências e alguns dos conselheiros simplesmente nunca aparecem, nem mesmo na posse. Essas ausências de conselheiros eleitos pode ser considerada um sintoma de um problema maior, que seria a queda de legitimidade e representatividade do CPM como um todo. A comparação da concorrência nas eleições, nos mapas e tabela a seguir, permite verificar em mais detalhes esse fenômeno. 
Mapa 10 - Concorrência (candidato/vaga) na eleição de 2015 dos CPM no Município de São Paulo

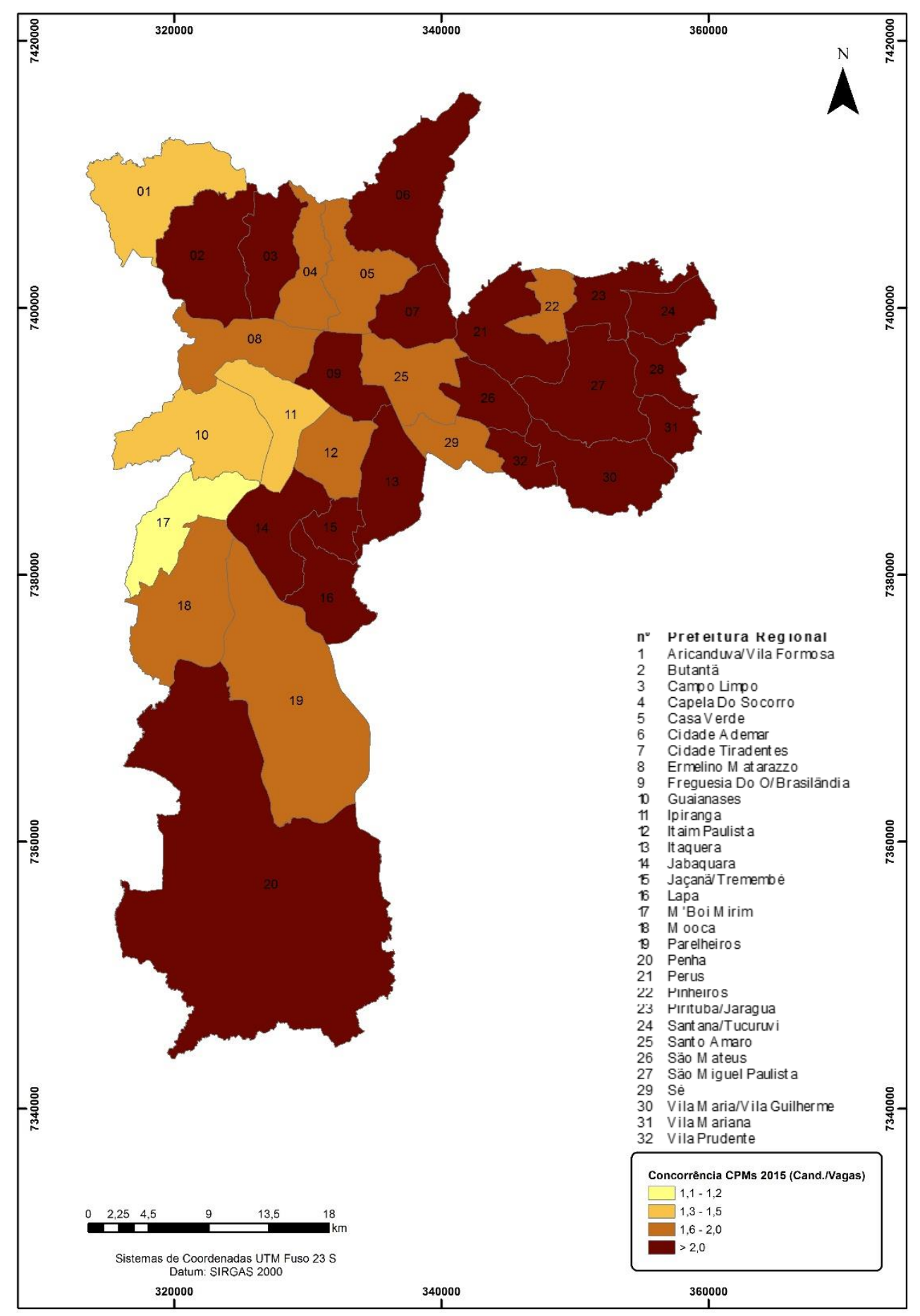

Fonte: Fonte: PMSP-SMRG (2013; 2015; 2017). Elaborado pelo autor. 
Mapa 11 - Concorrência (candidato/vaga) na eleição de 2017 dos CPM no Município de São Paulo

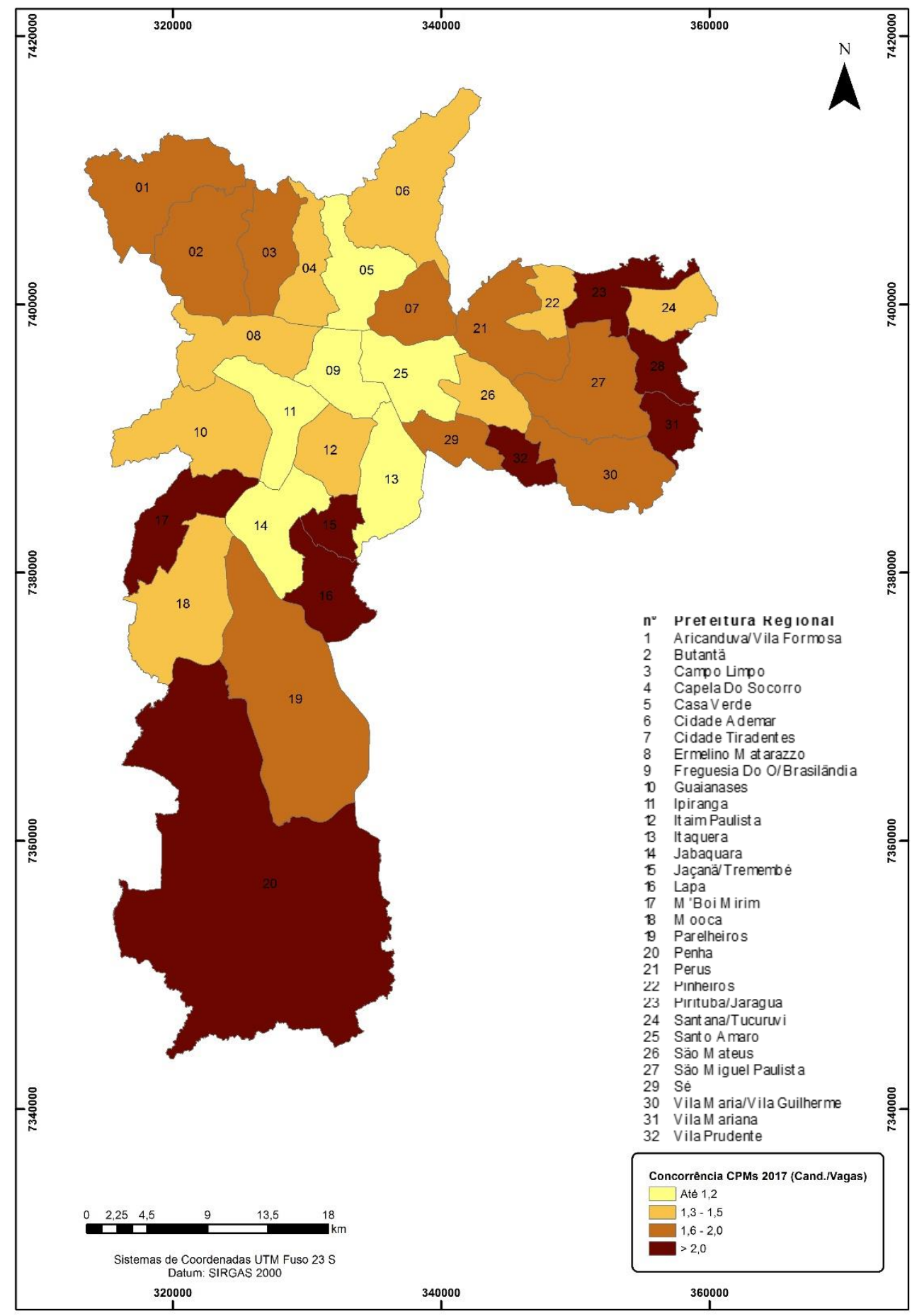

Fonte: Fonte: PMSP-SMRG (2013; 2015; 2017). Elaborado pelo autor. 
Tabela 8 - Concorrência (candidato/vaga) e variação percentual da concorrência nas

eleições dos CPM entre 2013 e 2017, por prefeitura regional

\begin{tabular}{|c|c|c|c|c|c|}
\hline Prefeitura Regional & \begin{tabular}{|l|} 
Candidato/ \\
Vaga 2013
\end{tabular} & \begin{tabular}{|l|} 
Candidato/ \\
Vaga 2015
\end{tabular} & \begin{tabular}{|l|} 
Candidato/ \\
Vaga 2017
\end{tabular} & \begin{tabular}{|c|} 
Variação 2013 \\
para 2015
\end{tabular} & $\begin{array}{c}\text { Variação } 2015 \\
\text { para } 2017\end{array}$ \\
\hline São Paulo & 2,5 & 2,1 & 1,5 & $-13,9 \%$ & $-30,4 \%$ \\
\hline Cidade Tiradentes & 3,7 & 2,4 & 3,1 & $-36,4 \%$ & $32,2 \%$ \\
\hline Jabaquara & 2,8 & 2,6 & 3,1 & $-5,9 \%$ & $19,8 \%$ \\
\hline Campo Limpo & 2,8 & 1,1 & 2,8 & $-59,9 \%$ & $148,6 \%$ \\
\hline Parelheiros & 2,9 & 3,3 & 2,6 & $12,3 \%$ & $-18,9 \%$ \\
\hline Sapopemba & 2,5 & 2,3 & 2,4 & $-6,2 \%$ & $2,4 \%$ \\
\hline Cidade Ademar & 2,5 & 2,7 & 2,3 & $8,0 \%$ & $-16,5 \%$ \\
\hline São Miguel Paulista & 2,9 & 3,2 & 2,2 & $12,1 \%$ & $-31,9 \%$ \\
\hline Guaianases & 1,5 & 3,0 & 2,2 & $107,9 \%$ & $-28,2 \%$ \\
\hline Perus & 3,2 & 1,5 & 2,0 & $-53,3 \%$ & $33,3 \%$ \\
\hline Capela Do Socorro & 1,9 & 1,8 & 1,8 & $-1,9 \%$ & $-4,7 \%$ \\
\hline Itaquera & 2,9 & 2,3 & 1,7 & $-23,0 \%$ & $-22,7 \%$ \\
\hline Freguesia Do Ó/Brasilândia & 2,5 & 2,1 & 1,7 & $-15,1 \%$ & $-18,3 \%$ \\
\hline Vila Maria/Vila Guilherme & 2,7 & 2,2 & 1,6 & $-20,7 \%$ & $-23,8 \%$ \\
\hline Pirituba/Jaraguá & 2,1 & 2,3 & 1,6 & $10,1 \%$ & $-29,3 \%$ \\
\hline Penha & 2,5 & 2,0 & 1,6 & $-18,4 \%$ & $-23,0 \%$ \\
\hline São Mateus & 2,4 & 2,4 & 1,6 & $-0,4 \%$ & $-35,1 \%$ \\
\hline Vila Prudente & 2,4 & 1,7 & 1,5 & $-29,3 \%$ & $-8,0 \%$ \\
\hline Lapa & 1,4 & 1,6 & 1,4 & $10,1 \%$ & $-11,3 \%$ \\
\hline Jaçanã/Tremembé & 2,9 & 2,4 & 1,4 & $-18,1 \%$ & $-42,3 \%$ \\
\hline Casa Verde/Cachoeirinha & 3,3 & 1,8 & 1,4 & $-44,0 \%$ & $-25,4 \%$ \\
\hline Vila Mariana & 1,8 & 1,7 & 1,4 & $-5,6 \%$ & $-20,2 \%$ \\
\hline Butantã & 2,3 & 1,5 & 1,3 & $-35,5 \%$ & $-7,5 \%$ \\
\hline Itaim Paulista & 3,8 & 2,9 & 1,3 & $-22,2 \%$ & $-55,2 \%$ \\
\hline M'Boi Mirim & 3,1 & 1,7 & 1,3 & $-43,4 \%$ & $-24,9 \%$ \\
\hline Ermelino Matarazzo & 2,3 & 1,6 & 1,3 & $-30,2 \%$ & $-19,0 \%$ \\
\hline Aricanduva/Vila Formosa & 2,3 & 2,5 & 1,3 & $5,8 \%$ & $-49,6 \%$ \\
\hline Pinheiros & 1,5 & 1,3 & 1,2 & $-16,7 \%$ & $-5,5 \%$ \\
\hline Santo Amaro & 2,1 & 2,8 & 0,8 & $34,4 \%$ & $-73,2 \%$ \\
\hline Sé & 1,6 & 2,2 & 0,7 & $41,3 \%$ & $-66,1 \%$ \\
\hline Ipiranga & 3,0 & 3,1 & 0,7 & $1,4 \%$ & $-75,9 \%$ \\
\hline Santana/Tucuruvi & 3,0 & 2,0 & 0,6 & $-33,3 \%$ & $-68,8 \%$ \\
\hline Mooca & 2,0 & 1,6 & 0,5 & $-17,9 \%$ & $-71,5 \%$ \\
\hline
\end{tabular}

Fonte: PMSP-SMRG (2013; 2015; 2017); PMSP-SMDU/Deinfo (2010). Elaborado pelo autor.

Nota: A tabela está ordenada a partir da relação candidato/vaga em 2017. Contabilizaram-se todas as vagas, inclusive às reservadas a imigrantes.

Observa-se na comparação entre os mapas que houve uma queda generalizada da concorrência para os CPM nos territórios paulistanos. Percebe-se que, apesar da queda, as prefeituras regionais que permanecem com maior concorrência são algumas das mais periféricas do município, como Cidade Tiradentes, Campo Limpo e Parelheiros. Nota-se pela tabela que na grande maioria das prefeituras regionais houve queda na concorrência ao se comparar duas eleições subsequentes, portanto trata-se de um fenômeno bem definido. 
Conforme indicado no capítulo anterior, essa queda de interesse da população pelos CPM não é atribuída pelos conselheiros ativos por questões de acessibilidade, questões econômicas ou de referência territorial. As pessoas que foram ouvidas tenderam a responder que a queda no interesse ocorreu pela falta de resultados práticos da participação, pelo desinteresse das prefeituras regionais - que não divulgam corretamente o CPM - e até mesmo a dificuldade de adaptação de alguns conselheiros com as dinâmicas das reuniões ordinárias.

Diante do quadro de crescentes ausências de conselheiros e baixa participação dos munícipes nas eleições, em 2017 o governo optou por reduzir o número de vagas de conselheiros, com a alegação de que essa redução poderia aumentar a competividade e fazer com que os conselheiros eleitos fossem mais identificados com seus eleitores. Contudo, o que se viu foi que mesmo com uma ampla redução no número de vagas, a concorrência em 2017 mais uma vez foi reduzida. Dessa forma, percebe-se que no médio prazo o não enfrentamento do problema das ausências pode esvaziar os CPM até o ponto de algum governo dissolvê-las.

\subsubsection{Projetos aprovados no âmbito dos CPM colocados em prática nos territórios}

Já foi mencionado o fato de que uma das maiores queixas dos conselheiros é a pouca efetividade da atuação política nos CPM, em razão do fato de que o conselho tem pouco poder de influência junto à prefeitura regional, além desta ter pouco poder de realização diante de suas limitações administrativas e orçamentárias. Nesse sentido, não é surpreendente a constatação de diversos conselheiros de que não houve conquistas significativas para os territórios como resultado de processos decisórios dos CPM.

Por outro lado, foi bastante surpreendente notar que houve grande variabilidade nos resultados atribuídos aos conselhos, pois embora alguns CPM tenham alegado não ter nenhuma conquista significativa para o seu território, outros citaram realizações muito importantes. Um exemplo do pessimismo sobre a atuação do CPM ocorreu na Prefeitura Regional da Sé, na qual os entrevistados foram unânimes ao afirmar que não houve nenhuma significativa de mudança nos bairros, alguma obra ou intervenção no espaço urbano. Em contrapartida, no CPM de Cidade Ademar os conselheiros atribuem a construção de 3.680 moradias no bairro Jardim Apurá e a construção 2 piscinões à atuação do CPM. Independente da possibilidade dessas conquistas terem ou não essa origem, é um fato digno de atenção os conselheiros atribuírem essas obras à atuação nos conselhos. No caso específico de Cidade Ademar, observou-se uma 
grande articulação entre o CPM e os movimentos por moradias e outros movimentos sociais da região.

Esses resultados levam a interpretação de que, a despeito de todas as dificuldades e constrangimentos do órgão, os CPM constituem um agente capaz de contribuir, mesmo que pontual e isoladamente, na produção de fragmentos da cidade. Mas a fragilidade institucional do órgão faz com que essas realizações tenham motivação mais política, no sentido da mobilização dos conselheiros e munícipes pressionando o poder público, e menos de atuação sistemática dos CPM enquanto órgãos de aconselhamento de governo. 


\section{CONSIDERAÇÕES FINAIS}

As divisões territoriais elaboradas pelo Estado são normatizações espaciais que buscam delimitar um campo de ação ou de apropriação territorial desta unidade política. No entanto, a partir das análises da pesquisa pode-se inferir que o Estado não deve ser sempre tratado de modo indistinto. Existem inúmeros interesses políticos antagônicos e sujeitos que disputam o poder no Estado, e não só pela via eleitoral. Os governos executivos e os parlamentos também disputam poder dentro do Estado uma vez já eleitos. Dessa forma, a presença de quadros territoriais tão incompatíveis e copiosos expressa em parte essa disputa de poder interna aos governos e parlamentos, pois grande parte dos governantes e legisladores procuram manter seu campo de ações inalterados ou ampliados. Essa lógica estende-se ao poder judiciário, o qual também mantém suas regionalizações exclusivas. $\mathrm{E}$ os conselhos participativos institucionalizados acabam participando dessa estrutura de disputas intraestatais.

Desse modo, compreende-se que a descentralização política-administrativa e a integração setorial da gestão urbana mostram-se inicialmente como imperativos técnicos e como pautas políticas progressistas, todavia as disputas internas pelo poder político intraestatal - sem esquecer as influências de cunho econômico - em geral transformam essas demandas em moedas políticas de troca em uma coalização para a governabilidade. Nesse sentido, compreende-se o motivo pelo qual mesmo a reforma proposta pelo estabelecimento das novas subprefeituras, por mais progressista que tenha sido o plano inicial, não conseguiu eliminar a prática de favores políticos em troca de formação de base aliada na Câmara Municipal.

Percebe-se ainda que o primeiro elemento a ser relativizado das propostas de descentralização política para garantir coalizões de governo são as instâncias participativas nos órgãos públicos. Ora eles são efetivamente eliminados, como ocorreu com o conselho de representantes das subprefeituras, ora essas instâncias são delegadas a uma função estritamente consultiva, como o caso dos numerosos conselhos temáticos municipais. O conselho participativo municipal nas prefeituras regionais insere-se nesse contexto. É curioso notar que a eleição dos conselhos participativos municipais elege representantes em prefeituras regionais, mas como a eleição precisa de regulamentação do Tribunal Superior Eleitoral, o pleito é organizado por meio de zonas eleitorais - divisão territorial que não possui compatibilidade de limites com as regionais. Isso demonstra parte da dificuldade que a população possui para 
compreender o quadro territorial da cidade, fato que influencia diretamente na capacidade de organização para ocupar os espaços participativos institucionais disponíveis.

A descrição desse quadro de constante loteamento político e econômico do Estado e o tratamento ambíguo dado pelos gestores públicos às instâncias participativas possivelmente estimulam a crescente desconfiança e insatisfação em relação à democracia representativa liberal e o sistema político vigente no Brasil como um todo. Talvez o fato da maioria da sociedade não conseguir discernir os padrões territoriais da capital paulista, ou de qualquer outra instância de governo, seja uma dimensão geográfica da negação à população de uma vida política mais ampla e da possibilidade de se autogovernarem - mesmo que parcialmente. Nesse sentido, Raffestin afirma:

Sendo "convencionais", tais divisões nem sempre são satisfatórias do ponto de vista existencial. Quando a malha é "desejada" por um poder, este se esforça por escolher o sistema que melhor corresponda ao seu projeto, pronto a transformar a existência daqueles que a ele estão submetidos, a menos que estes recuperem o seu poder para se oporem a outro poder (1993, p.170).

Além dessas questões relativas às referências espaciais que amparam a participação política, percebe-se que qualquer projeto sério de incorporação das populações na gestão das cidades deveria levar em conta as condições geográficas e socioeconômicas diferenciadas que cada habitante tem de comparecer a fóruns decisórios, conforme a discussão realizada no segundo capítulo. Então para que fosse possível ter uma maior equidade nas condições de participação política, seria necessário, por exemplo, uma maior difusão de instâncias participativas em áreas mais periféricas do município, gratuidade do transporte urbano para participar de reuniões, encontros realizados em finais de semana ou desconto de horas trabalhadas para fins de participação, etc. Medidas como essas sequer são pauta de debates em âmbito institucional.

Outro fator fundamental para se obter uma relativa possibilidade de participação política formal nas prefeituras regionais é a delegação por parte do poder municipal de maior autonomia a essa instância, sobretudo autonomia financeira. Do ponto de vista orçamentário, as regionais são preponderantemente órgãos de zeladoria urbana, os quais executam serviços urbanos previamente destacados, restando poucos recursos para serem investidos em serviços decididos pelos gestores e menos ainda pela população, por meio dos conselhos participativos. Esse é um dos motivos pelos quais é muito difícil encontrar projetos ou medidas relevantes aprovadas por iniciativas participativas no âmbito das prefeituras regionais 
A análise do fenômeno participativo nas prefeituras regionais da capital paulista mostra com clareza alguns dos limites desse tipo de expediente. É muito difícil vislumbrar alternativas institucionais a esses fenômenos que realmente transcendam o discurso e permitam uma genuína participação dos citadinos na definição dos rumos da cidade. A democracia representativa moderna, exaltada pelo discurso liberal como a melhor alternativa possível de sistema político, de maneira contraditória acaba por estimular a criação de instâncias participativas, ao mesmo tempo em que dificulta a ampliação do empoderamento desses canais participativos nas decisões políticas estatais. Pensamos como Lahorgue (2004, p. 63) ao afirmar que:

[O][...] Estado continua sendo um instrumento de acumulação. O que muda é a instância: agora, municipal, abandonando a idéia de um Estado Federal como integrador do território através de políticas de desenvolvimento. Além disso [...], a idéia de um Estado formado pelo consenso significa na prática deixar as contradições na sociedade civil intactas; as contradições viram "conflitos" que podem ser administrados e mediados pelo Estado (pelo menos em sua forma municipal). Chega a ser engraçado perceber que todo este discurso a respeito do enfraquecimento do papel do Estado, da emergência de organizações não-governamentais, de novas formas de parceria entre Estado e sociedade civil, etc., no final das contas simplesmente reforça o papel do Estado na acumulação capitalista via instâncias locais (LAHORGUE, 2004, p. 63).

Os resultados da pesquisa coletados em diversas reuniões de CPM e junto a relatos e entrevistas de conselheiros ativos mostraram que as condições de vida na cidade não condicionam de modo decisivo a participação. Mas não se pode negar a importância de propiciar melhores condições de participação para quem mora em locais mais desprivilegiados, prova disso é a discussão sobre a concessão de créditos gratuitos de transporte público aos conselheiros. Mais do que isso, no decorrer do processo de pesquisa, foi-se percebendo que os conselheiros ativos possivelmente não possam responder adequadamente pelos indivíduos que não frequentam as reuniões.

A pesquisa também mostrou que, apesar de todas as limitações legais e operacionais das prefeituras regionais, e mais ainda de um conselho consultivo associado a elas, foram detectadas experiências relevantes de produção da geografia da cidade por intermédio da ação dos CPM. Independentemente das limitações, os conselhos criam um arranjo político diferenciado no município, fiscalizam as ações da prefeitura em âmbito local e forçam um diálogo permanente da comunidade sobre os problemas dos bairros. A pressão política de caráter mais permanente pode trazer alguns resultados práticos, conforme observado em algumas experiências singulares. Nesse sentido, quase todas as pessoas que foram ouvidas durante as reuniões e 
entrevistas sobre os CPM reconheceram a importância da manutenção de instâncias participativas locais.

Percebe-se que muitos dos problemas relatados sobre as experiências dos conselhos seriam mitigados com um maior empoderamento dessas instâncias. Mas para isso ocorrer, seria necessária maior delegação de poder do município e das prefeituras regionais, o que poderia levar até mesmo a rediscussões constitucionais - haja vista o processo judicial sobre o conselho de representantes das subprefeituras, o qual está pendente no STF. No entanto, o empoderamento e maior abertura dessas instâncias poderiam causar conflitos grandes demais para serem aceitos pelo sistema estatal vigente, nos termos de uma democracia liberal.

Não se pode deixar de levar em consideração os resultados da pesquisa de Lavalle et al. (2016) que, ao analisar os padrões decisórios de diversos conselhos na cidade de Guarulhos, chegou a conclusão de que os conselhos com resultados mais exitosos, geralmente aqueles com algum tipo de indução federal, só começam a produzir decisões de modo mais sistemático a partir de alguns anos de funcionamento regular - no caso de Guarulhos, a partir a aproximadamente do sétimo ano. Embora o CPM não se enquadre nesse tipo de conselho mais robusto, o raciocínio também serve, de modo que há necessidade manter a regularidade do conselho tanto quanto possível para que ele possa começar a gerar resultados mais expressivos.

Nota-se que a questão da participação popular em canais institucionais para gerir as cidades é permeada por contradições. Dentre essas contradições está a forma x conteúdo, na qual se percebe que a forma "participativa" está plenamente incorporada na democracia representativa liberal, embora do ponto de vista substantivo não exista um empoderamento efetivo desses instrumentos de gestão. Outra contradição refere-se ao fato de que por meio dos conselhos os habitantes são convidados a decidir os rumos da produção da cidade coletivamente, ainda que eles estejam alienados dela desde o processo produtivo. 


\section{REFERÊNCIAS}

AES ELETROPAULO. Sobre a AES Eletropaulo: nossa história. 2013. Disponível em: $<$ https://www.aeseletropaulo.com.br/sobre-a-aes-eletropaulo/nossa-historia/conteudo/nossahistoria>. Acesso em: 25 jan. 2016.

ALMEIDA, Maria V. Os efeitos das condições socioeconômicas na participação política dos brasileiros. Dissertação de mestrado em Ciência Política - Instituto de Filosofia e Ciências Humanas, Universidade de Campinas, Campinas, 2017.

ALVAREZ, Isabel P. A segregação como conteúdo da produção do espaço urbano. In: VASCONCELOS; CORREAA; PINTAUDI (orgs.). A cidade contemporânea: segregação espacial. São Paulo: Contexto, 2013. p.111-126.

BRASIL. Constituição (1988). Constituição da República Federativa do Brasil de 1988. Disponível em: <http://www.planalto.gov.br/ccivil_03/constituicao/constituicao.htm>. Acesso em: 25 jan. 2016.

Lei $\mathbf{n}^{\mathbf{0}}$ 10.257, de 10 de julho de 2001. Regulamenta os artigos 182 e 183 da Constituição Federal, estabelece diretrizes gerais da política urbana e dá outras providências. Disponível em: <http://www.planalto.gov.br/ccivil_03/leis/LEIS_2001/L10257.htm>. Acesso em: 15 jul. 2017.

CÂMARA MUNICIPAL DE SÃO PAULO. Orçamento 2016. Dados abertos. Disponível em: <http://www.camara.sp.gov.br/orcamento2016/arquivos/>. Acesso em: 15 jun. 2016.

CARLOS, Ana F.A. A condição espacial. São Paulo: Contexto, 2011.

CAZZOLATO, José Donizete. Os bairros como instância local - contribuição metodológica para o caso de São Paulo. Dissertação de Mestrado em Geografia Humana - Faculdade de Filosofia, Letras e Ciências Humanas, Universidade de São Paulo, São Paulo, 2005. Disponível em: <http://www.teses.usp.br/teses/disponiveis/8/8136/tde-22022006-234813/pt-br.php>. Acesso em: 25 jan. 2016.

CEnTRo de estudos dA Metrópole. Município de São Paulo: Distritos em 2007. São Paulo: CEM/Cebrap, 2008. 1 mapa. Escala 1:400000. Disponível em: <http://www.fflch.usp.br/centrodametropole/598>. Acesso em: 25 jan. 2016.

Município de São Paulo: Subprefeituras em 2007. São Paulo: CEM/Cebrap, 2008. 1 mapa. Escala 1:400000. Disponível em: < http://www.fflch.usp.br/centrodametropole/575>. Acesso em: 25 jan. 2016.

CET (COMPANHIA DE ENGENHARIA DE TRÁFEGO). Operação de Tráfego - GP Brasil 2010.

Disponível

em:

<http://www.viajeo.eu/download/meetingsevents/Sao_Paolo12042011/presentations/09_valt er_vendramin_copy.pdf>. Acesso em: 25 out. 2013. 
_. Ajuda; Divisão da cidade em regiões. Disponível em: <http://cetsp1.cetsp.com.br/monitransmapa/agora/ajuda.htm〉. Acesso em: 25 jan. 2016.

Trânsito Agora. Disponível em: <http://cetsp1.cetsp.com.br/monitransmapa/agora/> . Acesso em: 25 jan. 2016.

CIGOLINI, Adilar Antonio. Território e criação de municípios no Brasil: Uma abordagem histórico-geográfica sobre a compartimentação do espaço. Tese de doutorado em Geografia Centro de Filosofia e Ciências Humanas, Universidade Federal de Santa Catarina, Florianópolis, $2009 . \quad$ Disponível em: $<$ https://repositorio.ufsc.br/bitstream/handle/123456789/92531/268885.pdf?sequence=1>. Acesso em: 25 jan. 2016.

CORTEZ, Bruno F.; MONTENEGRO, Flávio M.T.; BRITO, José A. de M. Censo Demográfico 2010 - definição das áreas de ponderação para o cálculo das estimativas provenientes do questionário da amostra. In: ENCONTRO NACIONAL DE ESTUDOS POPUlACIONAIS, XVIII, 2012, Águas de Lindoia. Anais... Águas de Lindóia, SP: ABEP, $2012 . \quad$ Disponível em: <http://www.abep.nepo.unicamp.br/xviii/anais/files/POSTER[167]ABEP2012.pdf>. Acesso em: 25 jan. 2016.

DÓRIA, Og. Município, o poder local: quinhentos anos de conflito entre o Município e o poder central. São Paulo: Editora Página Aberta/Scritta Editorial, 1992.

ESTADÃO DADOS. São Paulo que balança: a geografia do voto em São Paulo. Estadão.com.br. 2012. Disponível em: <http://estadaodados.com/saopauloquebalanca/>. Acesso em: 25 jan. 2016.

ESTADÃO. Verbas destinadas às Subprefeituras caem em 2014. 03 de outubro de 2014. Disponível em: <http://sao-paulo.estadao.com.br/noticias/geral,verbas-destinadas-assubprefeituras-caem-em-2015,1569939>. Acesso em: 25 jan. 2016.

FINATEC (FUNDAÇÃO DE EMPREENDIMENTOS CIENTÍFICOS E TECNOLÓGICOS). Descentralização e poder local: a experiência das subprefeituras no município de São Paulo. São Paulo: HUCITEC/FINATEC, 2004.

GESTÃO URBANA SP. Um Plano para fortalecer a participação popular nas decisões dos rumos da cidade. Disponível em: <http://gestaourbana.prefeitura.sp.gov.br/um-plano-parafortalecer-a-participacao-popular-nas-decisoes-dos-rumos-da-cidade-2/>. Acesso em: 25 jan. 2016.

GLOBO. Escândalo da máfia dos fiscais. Memória Globo. Disponível em: $<$ http://memoriaglobo.globo.com/programas/jornalismo/coberturas/mafia-dosfiscais/primeira-acusacao.htm>. Acesso em: 25 jan. 2016.

GOES, Airton. Papel de subprefeituras é criticado em debate sobre distritalização da cidade. Escola de Governo - Notícias, 7 mai. 2012. Disponível em: 
<http://escoladegoverno.org.br/index.php/noticias/1365-papel-de-subprefeituras-e-criticadoem-debate-sobre-distritalizacao-da-cidade>. Acesso em: 25 jan. 2016.

GRIN, José Eduardo. Construção e desconstrução das Subprefeituras na cidade de São Paulo no governo Marta Suplicy. Revista de Sociologia e Política, Curitiba, vol.23, n.55, set., 2015. Disponível em: <http://www.scielo.br/scielo.php?pid=S010444782015000300119\&script=sci_arttext>. Acesso em: 25 jan. 2016.

HADDAD, Emílio. Sobre o Estudo da Divisão da Cidade em Zonas Homogêneas: Aplicação para o Município de São Paulo. Tese de doutorado em Arquitetura e Urbanismo Faculdade de Arquitetura e Urbanismo, Universidade de São Paulo, São Paulo, 1987.

HARVEY, David. Do administrativismo ao empreendedorismo: a transformação da governança urbana no capitalismo tardio. In:__. A produção capitalista do espaço. Tradução: Carlos Szlak. São Paulo: Annablume, 2006. p. 163-190.

HARVEY, David. Os limites do capital. São Paulo: Boitempo, 2013.

HAESBAERT, Rogério. O Mito da Desterritorialização: Do "fim dos territórios" à multiterritorialidade. Rio de Janeiro: Bertrand Brasil, 2004.

. São Paulo - SP: Histórico. Cidades@. Infográficos. Disponível em: $<$ http://cidades.ibge.gov.br/painel/historico.php?lang=\&codmun=355030\&search=saopaulo|sao-paulo|infograficos:-historico>. Acesso em: 25 jan. 2016.

IPEA (INSTITUTO DE PESQUISA ECONÔMICA APLICADA); FJP (FUNDAÇÃO JOÃO PINHEIRO); PNUD (PROGRAMA DAS NAÇÕES UNIDAS PARA O DESENVOLVIMENTO). Atlas do Desenvolvimento Humano nas Regiões Metropolitanas Brasileiras. Brasília, 2014. Disponível em: <http://atlasbrasil.org.br/2013/pt/download/>. Acesso em: 5 mai. 2017.

JORNAL DA GENTE. Feldman contesta Conselho de Representantes. 28 de setembro de 2008. Disponível em: <http://jornaldagente.tudoeste.com.br/2008/09/28/feldman-contesta-conselhode-representantes/>. Acesso em 25 jan. 2016.

LAHORGUE, Mario L. Espaço e Políticas Urbanas: Porto Alegre sob o governo do Partido dos Trabalhadores. Tese de Doutorado em Geografia - Centro de Filosofia e Ciências Humanas, Universidade Federal de Santa Catarina, Florianópolis, 2004. Disponível em: $<$ https://repositorio.ufsc.br/bitstream/handle/123456789/87459/207236.pdf?sequence=1\&isAl lowed=y>. Acesso em: 15 jun. 2017.

LAMEIRÃO, Camila R. Estratégias políticas e gestão local: as subprefeituras do município do Rio de Janeiro. Dissertação de Mestrado em Ciência Política - Universidade Federal Fluminense, $\quad 2007 . \quad$ Niterói, Disponível em: <http://www.dominiopublico.gov.br/pesquisa/DetalheObraForm.do?select_action=\&co_obra $=78552>$. Acesso em: 15 jun. 2017. 
LAVALLE, Adrian Gurza; VERA, Ernesto Isunza. A trama da crítica democrática: da participação à representação e à accountability. Lua Nova, São Paulo , n. 84, p. 95-139, 2011 .Disponível em: <http://www.scielo.br/scielo.php?script=sci_arttext\&pid=S010264452011000300005\&lng=pt\&nrm=iso>. Acessos em 08 ago. 2017.

LAVALLE, Adrian Gurza; VOIGT, Jessica; SERAFIM, Lizandra. O que Fazem os Conselhos e Quando o Fazem? Padrões Decisórios e o Debate dos Efeitos das Instituições Participativas. Dados, Rio de Janeiro, v. 59, n. 3, p. 609-650, set. 2016. Disponível em: $<$ http://www.scielo.br/scielo.php?script=sci_arttext\&pid=S0011-

$52582016000300609 \& \operatorname{lng}=$ pt\&nrm=iso $>$. Acesso em 08 ago. 2017.

LEFEBVRE, Henri. Espaço e Política. Belo Horizonte: Editora UFMG, 2008.

MARIN, Pedro de L.; GUERRINI, Ana W. Participação na cidade de São Paulo no período de 2001 a 2016: do orçamento participativo ao programa de metas. Revista Brasileira de Políticas Públicas e Internacionais - RPPI, v. 2, n. 1, p.109-128. Disponível em: <http://periodicos.ufpb.br/ojs2/index.php/rppi/article/view/32664/17999>. Acesso em: 10 nov. 2017.

MENDES, Renato da Silveira. Os Bairros da Zona Norte e os Bairros Orientais. In: AZEVEDO, Aroldo (coord.). A Cidade de São Paulo: Estudos de geografia urbana. Vol.III, Aspectos da Metrópole Paulista. São Paulo: Companhia Editora Nacional, 1958. p.183-256.

METRÔ (COMPANHIA DO METROPOLITANO DE SÃO PAULO). Pesquisa de Origem e Destino 2007 - Região Metropolitana de São Paulo: Síntese das Informações da Pesquisa Domiciliar. São Paulo: Metrô/Secretaria de Estado dos Transportes Metropolitanos de São Paulo, 2008. Disponível em: <http://www.metro.sp.gov.br/metro/arquivos/OD2007/sintese_od2007.pdf>. Acesso em: 25 jan. 2016.

MÜLLER, Nice Lecoq. A área central da cidade. In: AZEVEDO, Aroldo (coord.). A Cidade de São Paulo: Estudos de geografia urbana. Vol.III, Aspectos da Metrópole Paulista. São Paulo: Companhia Editora Nacional, 1958. p.121-181.

MUMFORD, Lewis. A cidade na história: suas origens, transformações e perspectivas. Tradução: Neil R. da Silva. São Paulo: Martins Fontes, 1998da. 742 p.

PMSP (PREFEITURA DO MUNICÍPIO DE SÃO PAULO). Infocidade. Consulta de dados sobre a cidade de São Paulo. Disponível em: 〈http://infocidade.prefeitura.sp.gov.br/〉. Acesso em: 25 jan. 2016.

PMSP - SAR (SECRETARIA DAS ADMINISTRAÇÕES REGIONAIS). Nova Territorialização de São Paulo. São Paulo: PMSP - SAR, 1991.

PMSP - SECOM (SECRETARIA EXECUTIVA DE COMUNICAÇÃO). Ruas de São Paulo ganham novas placas de identificação. Prefeitura do Município de São Paulo, 05 fev. 2007. Disponível em: 
<http://www.prefeitura.sp.gov.br/cidade/secretarias/comunicacao/noticias/?p=129454>. Acesso em: 25 jan. 2016.

PMSP - SF (SECRETARIA MUNICIPAL DA FAZENDA). Quadro detalhado da despesa Exercício 2003 a 2016. São Paulo, 2017. Disponível em: <http://orcamento.sf.prefeitura.sp.gov.br/orcamento/execucao.php>. Aceso em: 20 out. 2017.

PMSP - SIS (SECRETARIA MUNICIPAL DE IMPLEMENTAÇÃO DAS SUBPREFEITURAS). Subprefeituras: Grupo de Articulação para Elaboração dos Planos Diretores. São Paulo: 2002. 1 mapa, color. Escala 1:250000. Disponível em: <http://ww2.prefeitura.sp.gov.br//arquivos/guia/mapas/0001/mapa_subprefeituras.jpeg>. Acesso em: 25 jan. 2016.

PMSP - SMDU (SECRETARIA MUNICIPAL DE DESENVOLVIMENTO URBANO); DEINFO (DEPARTAMENTO DE PRODUÇÃO E ANÁLISE DE INFORMAÇÃO). Regiões, Subprefeituras e Distritos. São Paulo: Infocidade; Território; Mapas, 2014. 1 mapa, color. Escala 1:250000. Disponível em: <http://infocidade.prefeitura.sp.gov.br/mapas/3_regioes_subprefeituras_e_distritos_2014_103 38.pdf>. Acesso em: 25 jan. 2016.

Demografia.

Disponível em: <http://infocidade.prefeitura.sp.gov.br/index.php?cat=7\&titulo=Demografia〉. Acesso em: 15 de ago. 2017.

PMSP - SME (SECRETARIA MUNICIPAL DE EDUCAÇÃO). A rede em mapas. Disponível em: <http://portal.sme.prefeitura.sp.gov.br/Main/School\#/>. Acesso em: 25 jan. 2016.

PMSP - SMS (SECRETARIA MUNICIPAL DE SAÚDE). Município de São Paulo por Coordenadoria Regional de Saúde e Subprefeituras. Disponível em: <http://intranet.saude.prefeitura.sp.gov.br/areas/ceinfo/divulgacao/Coord_Reg_Saude.pdf>. Acesso em: 25 jan. 2016.

PMSP - SMSP (SECRETARIA MUNICIPAL DE COORDENAÇÃO DAS SUBPREFEITURAS). Anexo I do Comunicado $\mathrm{n}^{\circ}$ 007/SMSP/GAB/SEC/05. Íntegra da decisão do Desembargador Luiz Tâmbara, Presidente do E. Tribunal de Justiça do Estado de São Paulo; ADIN (Ação Direta de Inconstitucionalidade de Lei) n ${ }^{\circ}$ 118.997.0/4-00. Diário Oficial da Cidade de São Paulo, ano 50, n.15, São Paulo, 21 jan. 2005, p.6. Disponível em: $<$ http://www.imprensaoficial.com.br/PortalIO/DO/BuscaDO2001Documento_11_4.aspx?link $=/ 2005 /$ diario $\% 2520$ oficial $\% 2520$ cidade $\% 2520 \mathrm{de} \% 2520$ sao $\% 2520$ paulo/janeiro/21/pag_000 6_1I253R7PSE85FeA0LL5R5C46Q6F.pdf\&pagina $=6 \&$ data $=21 / 01 / 2005 \&$ caderno=Di\%C3\% A1rio $\% 20$ Oficial $\% 20$ Cidade $\% 20 \mathrm{de} \% 20 \mathrm{~S} \% \mathrm{C} 3 \% \mathrm{~A} 3 \mathrm{o} \% 20$ Paulo\&paginaordenacao $=10006>$. Acesso em: 25 jan. 2016.

RAFFESTIN, Claude. Por uma Geografia do Poder. Tradução: Maria Cecília França. São Paulo: Ática, 1993.

SANTOS, César R.S. Dos negócios na cidade à cidade como negócio: uma nova sorte de acumulação primitiva no espaço. Cidades, Presidente Prudente, v.3, n.5, p.101-122, 2006. 
SÃO PAULO (Estado). Decreto no 1.454, de 5 e abril de 1907. Regulamenta a Lei $\mathbf{n}^{\circ} 1.038$, de 19 de Dezembro de 1906, que dispõe sobre a organização municipal. Disponível em: <http://www.al.sp.gov.br/repositorio/legislacao/decreto/1907/decreto-1454-05.04.1907.html>. Acesso em: 25 jan. 2016.

Decreto no 6.983, de 22 de fevereiro de 1935. Extingue o municipio de Santo Amaro, cujo territorio passa a fazer parte do municipio da Capital. Disponível em: <http://www.al.sp.gov.br/repositorio/legislacao/decreto/1935/decreto-6983-22.02.1935.html>. Acesso em: 25 jan. 2016.

Lei $\mathbf{n}^{\circ} \mathbf{1}$, de 18 de setembro de 1947. Dispõe sobre a organização dos municípios. Disponível em: <http://www.al.sp.gov.br/repositorio/legislacao/lei/1947/lei-118.09.1947.html>. Acesso em: 25 jan. 2016.

Lei $\mathbf{n}^{\mathbf{0}}$ 8.092, de 28 de fevereiro de 1964. Dispõe sobre Quadro Territorial, Administrativo e Judiciário do Estado. Disponível em: <http://www.al.sp.gov.br/repositorio/legislacao/lei/1964/lei-8092-28.02.1964.pdf>. Acesso em: 25 jan. 2016.

Decreto-Lei Complementar $n^{\circ}$ 9, de 31 de dezembro de 1969. Dispõe sobre a organização dos Municípios. Diário Oficial Estado de São Paulo, n.250, São Paulo, 31 out. 1969. Suplementos; Atos Legislativos. Disponível em: <http://www.imprensaoficial.com.br/PortalIO/DO/BuscaDO2001Documento_11_4.aspx?link =/1969/suplemento/executivo/dezembro/31/pag_0001_50UCRUNMH9LP0eBCCD190OF70 11.pdf\&pagina $=1 \&$ data $=31 / 12 / 1969 \&$ caderno $=$ Suplemento $\% 20-$

$\% 20$ Executivo\&paginaordenacao=100001>. Acesso em: 25 jan. 2016.

. Lei no 2.343, de 14 de maio de 1980. Altera o Quadro Teritorial-Administrativo do em: 25 jan. 2016.

Lei $\mathbf{n}^{\mathbf{0}}$ 4.954, de 27 de dezembro de 1985. Altera o Quadro Territorial Administrativo do Estado. Disponível em: <http://www.al.sp.gov.br/repositorio/legislacao/lei/1985/lei-495427.12.1985.html>. Acesso em: 25 jan. 2016.

Constituição (1989). Constituição do Estado de São Paulo de 1989. Disponível em: <http://www.legislacao.sp.gov.br/legislacao/dg280202.nsf/a2dc3f553380ee0f83256cfb00501 463/46e2576658b1c52903256d63004f305a>. Acesso em: 25 jan. 2016.

Lei Complementar $\mathbf{n}^{\mathbf{0}}$ 651, de 31 de julho de 1990. Dispõe sobre a criação, fusão, incorporação e desmembramento de Município e criação, organização e supressão de Distritos. Disponível em: <http://www.al.sp.gov.br/repositorio/legislacao/lei.complementar/1990/lei.complementar651-31.07.1990.html>. Acesso em: 25 jan. 2016. 
Lei Complementar $\mathbf{n}^{0} \mathbf{1 . 1 0 8}$, de 6 de maio de 2010. Altera a Organização e a Divisão Judiciárias do Estado, e dá outras providências. Disponível em: <http://www.al.sp.gov.br/repositorio/legislacao/lei.complementar/2010/lei.complementar1108-06.05.2010.html>. Acesso em 25 jan. 2016.

SÃO PAULO (Município). Decreto no 3.270, de 29 de setembro de 1956. Dispõe sobre a divisão do território do Município de São Paulo em Subprefeituras, e dá outras providências. Disponível em: <http://camaramunicipalsp.qaplaweb.com.br/iah/fulltext/decretos/D3270.pdf >. Acesso em: 25 jan. 2016.

Decreto n⿳ 6.236, de 13 de outubro de 1965. Institui as Administrações Regionais e dá outras providências. Disponível em: <http://camaramunicipalsp.qaplaweb.com.br/iah/fulltext/decretos/D6236.pdf>. Acesso em: 25 jan. 2016.

Lei $\mathbf{n}^{\circ}$ 10.089, de 26 de junho de 1986. Cria Subprefeituras, e dá outras providências. Disponível em: <http://cmspbdoc.inf.br/iah/fulltext/leis/L10089.pdf>. Acesso em: 26 jan. 2015.

Decreto n⿳ 25.085, de 27 de novembro de 1987. Altera a denominação e a composição das Subprefeituras, e dá outras providências. Disponível em: <http://cmspbdoc.inf.br/iah/fulltext/decretos/D25085.pdf>. Acesso em: 26 jan. 2015.

Lei Orgânica do Município de São Paulo (1990). Disponível em: <http://www.prefeitura.sp.gov.br/cidade/secretarias/upload/educacao/cme/LOM.pdf $>$. Acesso em: 25 jan. 2016.

Exposição de Motivos. Projeto de Lei no 184, de 19 de junho de 1990. Institui a divisão geográfica da área do Município em Distritos e dá outras providências. Disponível em: <http://camaramunicipalsp.qaplaweb.com.br/iah/fulltext/projeto/PL0184-1990.pdf>. Acesso em: 25 jan. 2016.

Projeto de Lei $\mathbf{n}^{0}$ 234, de 16 de maio de 1991. Dispõe sobre a reorganização administrativa da Prefeitura do Município de São Paulo; cria as Subprefeituras e Secretarias Municipais, extingue Secretarias, e dá outras providências. Disponível em: <http://www2.camara.sp.gov.br/projetos/1991/00/00/0I/1H/00000I1H2.pdf>. Acesso em: 25 jan. 2016.

Lei $\mathbf{n}^{\mathbf{0}}$ 11.220, de 20 de maio de 1992. Institui a divisão geográfica da área do Município em Distritos, revoga a Lei $\mathrm{n}^{\circ}$ 10.932, de 15 de janeiro de 1991, e dá outras providências. Disponível em: <http://camaramunicipalsp.qaplaweb.com.br/iah/fulltext/leis/L11220.pdf>. Acesso em: 25 jan. 2016.

Decreto $\mathbf{n}^{\mathbf{0}}$ 37.085, de 3 de outubro de 1997. Regulamenta a lei $\mathrm{n}^{\circ} 12.490$, de 3 de outubro de 1997. Autoriza o Executivo a implantar Programa de Restrição ao Trânsito de Veículos Automotores no Município de São Paulo. Disponível em: 
<http://camaramunicipalsp.qaplaweb.com.br/iah/fulltext/decretos/D37085.pdf>. Acesso em: 25 jan. 2016.

Lei $\mathbf{n}^{\mathbf{0}}$ 13.399, de $1^{\circ}$ de agosto de 2002. Dispõe sobre a criação de Subprefeituras no Município de São Paulo, e dá outras providências. Disponível em: <http://camaramunicipalsp.qaplaweb.com.br/iah/fulltext/leis/L13399.pdf>. Acesso em: 25 jan. 2016.

Lei $\mathbf{n}^{\circ}$ 13.430, de 13 de setembro de 2002. Plano Diretor Estratégico. Disponível em: $<$ http://ww2.prefeitura.sp.gov.br/secretarias/desenvolvimentourbano/plano_diretor/integra/for mato_do_arquivo.pdf >. Acesso em: 25 jan. 2016.

Lei $\mathbf{n}^{\mathbf{0}}$ 13.881, de 30 de julho de 2004. Dispõe sobre a criação, composição, atribuições e funcionamento do Conselho de Representantes e dá outras providências. Disponível em: <http://cmspbdoc.inf.br/iah/fulltext/leis/L13881.pdf>. Acesso em: 25 jan. 2016.

Decreto $\mathbf{n}^{\mathbf{0}} \mathbf{5 3 . 8 8 7}$, de 8 de maio de 2013. Confere nova regulamentação à Lei $\mathrm{n}^{\circ}$ 13.241, de 12 de dezembro de 2001, que dispõe sobre a organização dos serviços do Sistema de Transporte Coletivo Urbano de Passageiros na Cidade de São Paulo e autoriza o Poder Público a delegar sua execução; revoga os Decretos n 42.736, de 19 de dezembro de 2002 e n ${ }^{\circ}$ 47.139 de 27 de março de 2006. Disponível em: <http://camaramunicipalsp.qaplaweb.com.br/iah/fulltext/decretos/D53887.pdf>. Acesso em: 25 out. 2013.

Lei $\mathbf{n}^{\circ}$ 15.764, de 27 de maio de 2013. Dispõe sobre a criação e alteração da estrutura organizacional das Secretarias Municipais que especifica, cria a Subprefeitura de Sapopemba e institui a Gratificação pela Prestação de Serviços de Controladoria. Disponível em: <http://camaramunicipalsp.qaplaweb.com.br/iah/fulltext/leis/L15764.pdf>. Acesso em: 25 jan. 2016.

Decreto $\mathbf{n}^{\mathbf{0}}$ 54.156, de $1^{\circ}$ de agosto de 2013. Regulamenta os artigos 34 e 35 da Lei $\mathrm{n}^{\circ}$ 15.764, de 27 de maio de 2013, que dispõem sobre a criação, composição e atribuições do Conselho Participativo Municipal em cada Subprefeitura. Disponível em: <http://cmspbdoc.inf.br/iah/fulltext/decretos/D54156.pdf>. Acesso em: 25 jan. 2016.

Lei $\mathbf{n}^{\circ}$ 16.050, de 31 de julho de 2014. Aprova a Política de Desenvolvimento Urbano e o Plano Diretor Estratégico do Município de São Paulo e revoga a Lei $n^{\circ} 13.430 / 2002$. Disponível em: <http://gestaourbana.prefeitura.sp.gov.br/marco-regulatorio/planodiretor/texto-da-lei-ilustrado/>. Acesso em: 15 jun. 2017.

Lei $\mathbf{n}^{\mathbf{0}} \mathbf{1 6 . 3 3 4}$, de 30 de dezembro de 2015. Estima a receita e fixa a despesa do Município de São Paulo para o exercício de 2016. Disponível em: $<$ http://documentacao.camara.sp.gov.br/iah/fulltext/leis/L16334.pdf>. Acesso em: 15 jun. 2016.

SPOSATI, Aldaíza. Cidade em Pedaços. Organização: José Roberto de Toledo. São Paulo: Brasiliense, 2001. 
TEIXEIRA, Marco Antônio C. Negociação política e as formas de interação Executivo Legislativo no Brasil no período de 1983 a 1992. Cadernos Gestão Pública e Cidadania, São Paulo, vol.9, n.40, pp.1-82, jun. 2004.

TRIBUNAL SUPERIOR ELEITORAL (TSE). Eleições no Brasil: Uma História de 500 anos. Brasília: Tribunal Superior Eleitoral, 2014. Disponível em: <http://www.tse.jus.br/hotsites/catalogo-publicacoes/pdf/tse-eleicoes-no-brasil-uma-historiade-500-anos-2014.pdf >. Acesso em: 25 jan. 2016.

VASCONCELOS, Pedro de A. As metamorfoses do conceito de cidade. Mercator, Fortaleza, v. 14, n. 4, Número Especial, p. 17-23, dez. 2015. Disponível em: <http://www.scielo.br/pdf/mercator/v14nspe/1984-2201-mercator-14-04-spe-0017.pdf>. Acesso em> 12 out. 2017. 


\section{APÊNDICES \\ APÊNDICE A - Questionário semiestruturado destinado a conselheiros e munícipes presentes em reuniões ordinárias}

Nome:

Prefeitura Regional:

1 Quantos conselheiros em média estão presentes nas reuniões do CPM da sua prefeitura regional?

2 Quantos cidadãos que não são conselheiros em média comparecem nas reuniões do CPM da sua prefeitura regional?

3 Os conselheiros repassam as discussões das reuniões aos eleitores ou às comunidades que representam? Em caso positivo, qual a forma de divulgação?

4 A abrangência territorial da prefeitura regional é adequada à participação de toda a população dos distritos? Ou você acha que deveria haver um maior número de CPM na mesma região?

5 A localização da sede da prefeitura regional ou do local de reunião tem acesso fácil para toda população da área de abrangência da regional?

6 Há orçamento específico destinado a gastos com projetos aprovados pelo conselho participativo?

7 Houve algum projeto significativo aprovado por iniciativa do CPM da sua prefeitura regional? A prefeitura regional elaborou alguma obra nos bairros por orientação do CPM? 
8 Como é a relação entre os conselheiros e os subprefeitos/prefeitos regionais? Há proximidade e cooperação? A prefeitura regional executa ações e diretrizes decididas nas reuniões do CPM da sua região?

9 Você concorda com a redução no número de conselheiros que entrará em vigor a partir de $2018 ?$

10 Quais são os maiores motivos para ausências de conselheiros e cidadãos nas reuniões do CPM da sua prefeitura regional?

11 Quais medidas poderiam ser tomadas para aumentar a participação de conselheiros e cidadãos no CPM da sua região?

12 Você acha que há conflitos de atribuições entre a prefeitura regional e secretarias setoriais e entre o CPM e fóruns de participação social setoriais?

13 Há presença de partidos políticos e movimentos sociais no conselho? Em caso positivo, você acha que esses grupos fortalecem ou prejudicam o CPM?

14 Os resultados da participação são maiores no CPM ou em associações civis e movimentos sociais? 
APÊNDICE B - Localização dos conselhos participativos municipais visitados e consultados na pesquisa

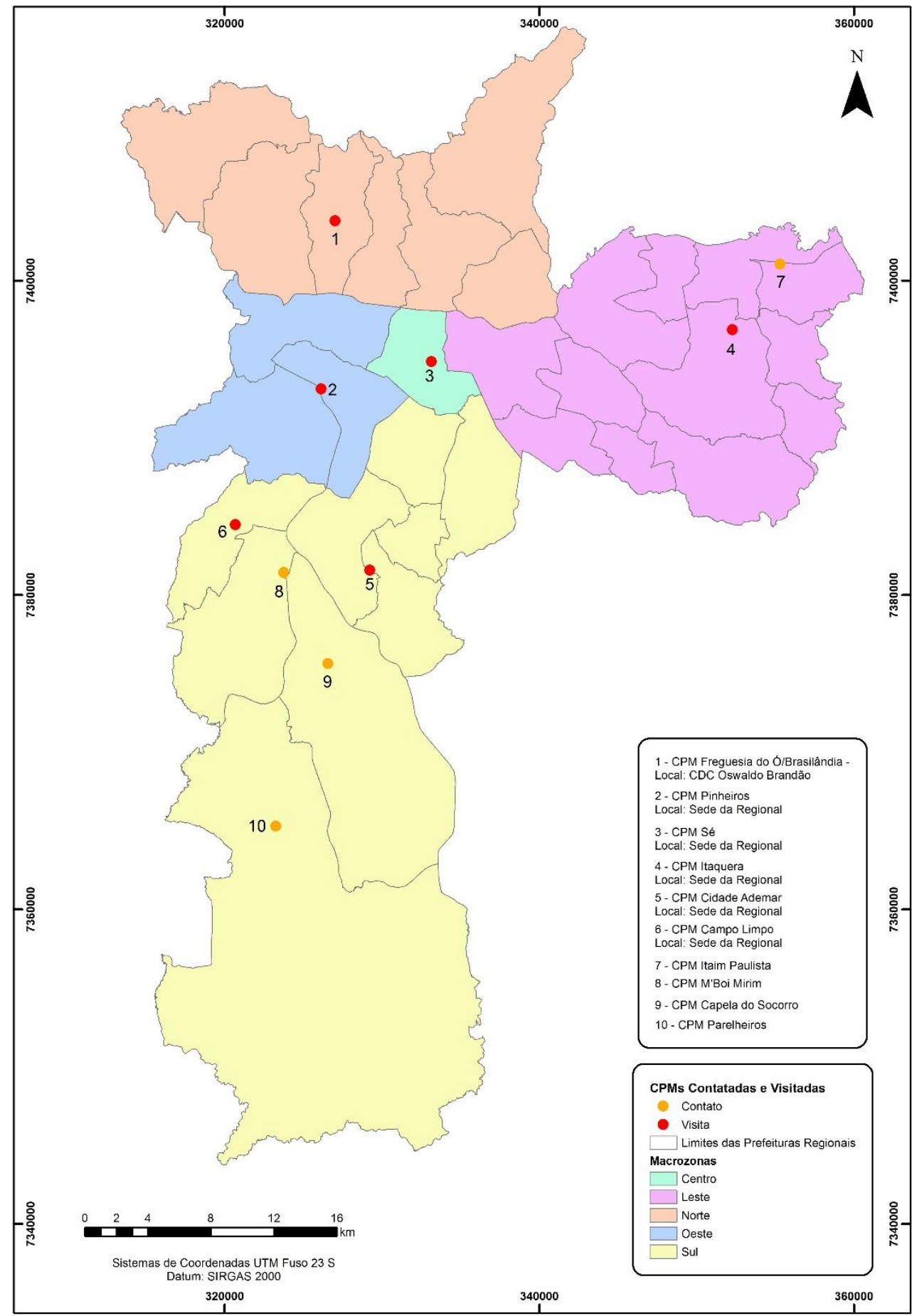

Fonte: Elaborado pelo autor. 